\title{
BIOLOGICAL ACTIVITIES, MECHANISMS OF ACTION AND BIOMEDICAL PROSPECT OF THE ANTITUMOR ETHER PHOSPHOLIPID ET-18-OCH (EDELFOSINE), A PROAPOPTOTIC AGENT IN TUMOR CELLS
}

Consuelo Gajate and Faustino Mollinedo*

Centro de Investigación del Cáncer, Instituto de Biología Molecular y Celular del Cáncer, CSIC-Universidad de Salamanca, Campus Miguel de Unamuno, E-37007 Salamanca, Spain.

Key words: ET-18- $\mathrm{OCH}_{3}$; edelfosine; antitumor ether lipid; apoptosis; lipid metabolism; mechanism of action; signal transduction; cancer.

Correspondence address:

Faustino Mollinedo

Centro de Investigación del Cáncer

Instituto de Biología Molecular y Celular del Cáncer

CSIC-Universidad de Salamanca

Campus Miguel de Unamuno

E-37007 Salamanca

Spain

Tel.: (+34)-923 294806

Fax: (+34)-923 294795

E-mail: fmollin@usal.es 


\section{FOOTNOTES}

*Correspondence to: Centro de Investigación del Cáncer, Instituto de Biología Molecular y Celular del Cáncer, CSIC-Universidad de Salamanca, Campus Miguel de Unamuno, E-37007 Salamanca, Spain. Tel.: (+34)-923 294806. Fax: (+34)-923 294795. E-mail: fmollin@usal.es

Abbreviations used are: AEL, antitumor ether lipid; AEP, alkyl ether phospholipid; ALL, acute lymphoblastic leukemia; AML, acute myelogenous leukemia; ALPs, alky-lysophospholipid analogues; ara-C, cytosine arabinoside (1- $\beta$-D-arabinofuranosylcytosine); APC, alkylphosphocholine; ATL, antitumor lipids; BFU-E, burst-forming unit erythroid; ET-18$\mathrm{OCH}_{3}$, 1-O-octadecyl-2-O-methyl-rac-glycero-3-phosphocholine (edelfosine); bFGF, basic fibroblastic growth factor; BSA, bovine serum albumin; CCT, CTP:phosphocholine cytidylyltransferase; CFU-E, colony-forming unit erythroid; CFU-GEMM, colony-forming unit with myeloid and erythroid potential; CFU-GM, colony-forming unit granulocyte and monocyte; EAE, experimental allergic encephalomyelitis; EEL-12, liposomes composed of dioleoylphosphatidylcholine/cholesterol/dioleoylphosphatidylethanolamine-glutaric acid /ET18- $\mathrm{OCH}_{3}$ (4:3:1:2, v/v); FCS, fetal calf serum; EGFR, epidermal growth factor receptor; G-CSF, granulocyte-colony stimulating factor; HDL, high density lipoprotein; HPC, hexadecylphosphocholine (miltefosine); Hsp, heat shock protein; i.p., intraperitoneal; i.v, intravenous; JNK, c-Jun $\mathrm{NH}_{2}$-terminal kinase; kDa, kilodalton; $\mathrm{LD}_{50}$, lethal dose or drug concentration causing 50\% of death in a test group of animals; LPC, 2-lysophosphatidylcholine; MAPK, mitogen-activated protein kinase; MC540, merocyanine 540; MDR, multidrug resistance; NK, natural killer; NSCLC, non-small cell lung carcinoma; OMG, 1-O-octadecyl-2O-methyl-rac-glycerol; PAF, platelet-activating factor (1-O-alkyl-2-acetyl-sn-glycero-3phosphocholine); PBPC, peripheral blood derived progenitor cells; PDT, photodynamic therapy; PC, phosphatidylcholine; PI-3-kinase, phosphatidylinositol-3-kinase; PI-PLC, phosphatidylinositol-specific phospholipase C; $\mathrm{PKB}$, protein kinase B; PKC, protein kinase C; PLA2, phospholipase $A_{2}$; PLC, phospholipase C; PLD, phospholipase D; PMA, phorbol-12myristate-13-acetate; s.c., subcutaneous; SCLC, small cell lung carcinoma. 


\begin{abstract}
The antitumor ether lipid ET-18- $\mathrm{OCH}_{3}$ (edelfosine) is the prototype of a new class of antineoplastic agents, synthetic analogues of lysophosphatidylcholine, that shows a high metabolic stability, does not interact with DNA and shows a selective apoptotic response in tumor cells, sparing normal cells. Unlike currently used antitumor drugs, ET-18-OCH $\mathrm{OCH}_{3}$ does not act directly on the formation and function of the replication machinery, and thereby its effects are independent of the proliferative state of target cells. Because of its capacity to modulate cellular regulatory and signaling events, including those failing in cancer cells, like defective apoptosis, ET-18- $\mathrm{OCH}_{3}$, beyond its putative clinical importance, is an interesting model compound for the development of more selective drugs for cancer therapy. Although ET-18$\mathrm{OCH}_{3}$ enhances host defense mechanisms against tumors, its major antitumor action lies in a direct effect on cancer cells, inhibiting phosphatidylcholine biosynthesis and inducing apoptosis in tumor cells. Recent progress has allowed unraveling the molecular mechanism underlying the apoptotic action of $\mathrm{ET}-18-\mathrm{OCH}_{3}$, leading to the notion that $\mathrm{ET}-18-\mathrm{OCH}_{3}$ is selectively incorporated into tumor cells and induces cell death by intracellular activation of the cell death receptor Fas/CD95. This intracellular Fas/CD95 activation is a novel mechanism of action for an antitumor drug and represents a new way to target tumor cells in cancer chemotherapy that can be of interest as a new framework in designing novel antitumor drugs. ET-18- $\mathrm{OCH}_{3}$ and some analogues are pleiotropic agents that affect additional biomedical important diseases, including parasitic and autoimmune diseases, suggesting new therapeutic indications for these compounds.
\end{abstract}




\section{Introduction}

Synthetic ether-linked analogues of lysophospholipids were synthesized in the late 60s as metabolically stable analogues of lysophosphocholine, and constitute a new class of antitumor drugs that do not directly target DNA, but seem to target the cell membrane. These synthetic lipid molecules were the first antineoplastic agents that did not act directly on the formation and function of the cellular replication machinery, and therefore their effects were independent of the proliferative state of the target cells. In the last three decades a wealth of knowledge on their properties and actions has been accumulated. A number of excellent reviews have appeared concerning the antitumor activities and biochemical processes affected by these synthetic etherlinked analogues of lysophospholipids and by synthetic alkylphosphocholines, collectively known as antitumor lipids (ATLs) [1-8]. However, some of the actions assigned to these lipid molecules can be questioned as they are evidenced at drug concentrations much higher than those required for achieving their antitumor effects. This is of particular importance when dealing with lipidic drugs, as lipids are prone to promote nonspecific events, especially when used at high concentrations that can prevent or divert attention from the specific and relevant actions. Conflicting and contradictory observations among different groups, using a wide diversity of drug concentrations and cell types, together with an increasing number of reports suggesting the participation of ATLs in a wide array of physiological processes as well as the involvement of different signaling processes in the mechanism of action of ATLs, have led to a certain confusion to discern the main biological effects exerted by these drugs and the underlying primary signaling routes from secondary and irrelevant events. A pivotal development in understanding the mechanism of action of ATLs was the demonstration in 1993 that these lipids induced apoptosis in target cells [9,10], and this key finding accounts for the cytotoxic activity of the ether lipids. Furthermore, we have recently found that ET-18- $\mathrm{OCH}_{3}$ (edelfosine), considered as the major prototype of ATLs, induces selectively apoptosis in tumor cells, sparing normal cells, and that this lipid drug triggers directly the apoptotic machinery of tumor cells $[11,12]$, unlike other antitumor drugs that promote indirectly apoptosis. Accordingly, current investigations try to unravel how this apoptotic-directed killing is triggered. Recent evidence indicates that $\mathrm{ET}-18-\mathrm{OCH}_{3}$ is the first antitumor drug acting through activation of the cell death receptor Fas/CD95 [12]. There is now a renewed and growing interest in these ATLs as antitumor agents due to their selectivity against tumors that is in part due to their high metabolic stability. During the last eight years a number of key findings have been reported that allow to lay the foundations to understand and unravel the mechanism of action of these promising 
antitumor drugs. These novel findings indicate that ATLs represent a new type of antitumor drugs targeting for the apoptotic machinery and plasma membrane. In addition, a number of preclinical data have been reported that seem to bring a putative clinical application closer. The present review covers the state of the art in the incorporation, metabolism, and mechanism of action of the antitumor drug $\mathrm{ET}-18-\mathrm{OCH}_{3}$, which has become the effective and standard prototype of ATLs. A major purpose of this review is to emphasize the important effect of ET18- $\mathrm{OCH}_{3}$ in triggering apoptosis in tumor cells through the activation of the apoptotic machinery that was dormant in cancer cells, as well as to discuss the need for searching new proapoptotic drugs in the treatment of cancer. This review also summarizes the preclinical and clinical experience obtained to date with this drug on cancer treatment and on new putative additional biomedical indications that can also be of major importance in near future.

\section{Two major types of antitumor lipids}

Synthetic antitumor lipids (ATLs) can be classified into two major categories (Fig. (1)): a) the alkyl ether phospholipids (AEPs), widely referred to collectively as antitumor ether lipids (AELs) or alkyl-lysophospholipid analogues (ALPs), containing ether bonds in the glycerol backbone of the phospholipid, as exemplified by 1-O-octadecyl-2-O-methoxy-rac-glycero-3phosphocholine (ET-18-OCH 3 ; edelfosine); b) and the alkylphosphocholines (APCs), lacking the glycerol backbone and formed by a simple long-chain alcohol esterified to a phosphobase, as exemplified by hexadecylphosphocholine (HPC; miltefosine). All of these ATLs are distinguished by their low rates of metabolism in vitro and in vivo. AEPs and APCs share a number of biological actions, but they seem to act differently. Furthermore, new classes of synthetic ATLs are being synthesized with promising antitumor activities, including: a) sugarcontaining analogues of lysophosphatidylcholine [13-17]; b) phosphonate-derived ether lipids $[18,19]$; c) plasmenyl analogues of ET-18- $\mathrm{OCH}_{3}$ [20,21]; d) new analogues of HPC, such as erucylphosphocholine [22,23] and perifosine [24,25]; e) phosphocholine-containing analogues of sphingomyelin [26]; f) alkylphosphonophosphate analogues of 1- $\beta$-D-arabinofuranosylcytosine (ara-C), such as cytoros [27]. The present review focuses on the current knowledge and new insights about the uptake, metabolism, mechanism of action and biomedical activities of ET-18$\mathrm{OCH}_{3}$, as the prototype of AEPs, that can be extended to other ATLs. 


\section{Cancer chemotherapy and apoptosis}

There is a need to overcome the dead-lock in the present chemotherapeutical state of cancer treatment with further developments of new chemotherapeutic drugs different from the classical compounds used in clinical practice. The era of chemotherapy was ushered in by the introduction of polyfunctional alkylating agents in the early 1940's. Since then, a wide array of antitumor drugs has become available. Most of the chemotherapeutic agents used in clinic exert their major antitumor effects by affecting either DNA itself, DNA synthesis or cell division, thus inhibiting cells that undergo proliferation. However, the results obtained from the use of these drugs have been rather poor. An undesirable consequence of these drugs actions is that those normal tissues that have a high rate of cellular proliferation bear the brunt of toxic side effects, leading to a number of clinical manifestations of toxicity. These normal tissues include the normal bone marrow (leading to anemia, leukopenia -infection-, thrombocytopenia -bleeding-), the gastrointestinal epithelial cells (diarrhea, vomiting, nausea, surface ulcerations), and the cells of the hair follicles (alopecia).

In this regard, the lack of selectivity of the current antitumor agents is a major problem in cancer chemotherapy, and leads to compounds with a rather poor therapeutic index, defined as the ratio of maximum tolerated dose/minimum effective dose. Medically useful drugs should ideally have a high therapeutic index. The only modest progress in cancer chemotherapy over the past sixty years suggests that some of the frameworks used for targeting the cancer cell are wrong. Perception of the malignant cell as having only an uncontrolled proliferation is one of such frameworks. The rather modest impact of antiproliferative drugs in clinic is not surprising since many tumors have a low growth capacity. In contrast, increasing evidence is leading to the conception of a tumor cell as a cell mainly defective in triggering its own death by apoptosis. In this way of thinking, a common feature in the tumor cell would be a blockade or deficiency in its capacity to trigger its own cell death by apoptosis. This defective apoptosis could be even a more relevant and general feature than an unregulated proliferation in the process of tumorigenesis.

It was previously considered that drug- or radiation-induced damage, like DNA strand breaks, were directly responsible for the death of the cell, leading to a metabolic catastrophe. However, it is now assumed that cells sense this damage and react according to their phenotype [28], that is to say cells respond to a drug-induced perturbation of cellular metabolism. Cells sense alterations or damages in the cell metabolism or in the distinct biochemical processes required for the normal life of the cell or in the genome through the presence of "sensors", calibrate these lesions and mount a response to these aggressions. When this metabolic, 
biochemical or DNA damage is excessive or difficult to be repaired, the cell decides to selfdestruct altruistically by apoptosis avoiding in this way to threaten the health of neighbor cells and tissues. The failure of some tumor cells to die following a chemotherapeutic treatment may be due to their resistance to engage apoptosis. This implies the existence of a molecular threshold for the engagement of cell death, that we coin as "apoptosis threshold", in response to damage that is set differently in distinct cell types (Fig. (2)). Differences in apoptosis thresholds between different cell types may reflect differences in the expression or sensitivity of cellular sensors or in down-stream events set in motion by the sensors. Tumor cells may either inhibit the molecular processes that lead to their own death, and/or increase remarkably the apoptosis threshold required to realize that they are receiving a signal driving them to commit suicide. There are big differences among different cell types concerning the capacity to invoke a response after damage, some cells may die readily and others may be very resistant. Most of the human cancers (about 86\% of all cancer types) derive from epithelial cells (carcinoma). This suggests that epithelial tissue has a high apoptosis threshold, that is it tolerates a high number of external insults or damage before mounting an apoptotic response, and thereby this tissue might show a higher predisposition to accumulate mutations leading ultimately to cancer. The high apoptotic threshold of epithelium can be due to the fact that is exposed to environmental threats and therefore should be more permissible to risk some damage in order to avoid a high cell death rate. In contrast, the bone marrow, that is protected from external insults, would show a lower threshold for the engagement of cell death and this might explain why hematopoietic and immune system tumors are relatively much less frequent (about 8\% of all cancer types). This low apoptotic threshold also explains the deleterious effects and the ease of chemotherapy- and radiation-induced cell death in the bone marrow.

Carcinogenesis is a multistage process which involves damage to the genome, accumulating mutations in specific genes. This leads to the modification of either the activity or the amount of protein products coded by those genes, perturbing in this way the normal cell function. These changes, promoted originally by a genomic damage, are detected by cellular sensors, which, in turn, set several signaling mechanisms leading to a rapid apoptotic cell death in those cells with a low or normal apoptotic threshold (Fig. (1)). In this way, the timely induction of apoptosis would prevent tumor development. However, cancer cells try to survive at any cost, and thereby inhibit or get rid of sensors and apoptotic signaling (Fig. (3)), either modifying their expression levels or function, that otherwise could lead to their own cell death. Thus, a tumor cell shows (Fig. (3)): a) inhibition of sensors promoting apoptosis; b) inhibition or 
blockade of apoptosis signaling; c) potentiation of survival signaling. These effects lead to an abnormally high apoptosis threshold in tumor cells (Figs. (2) and (3)). Impaired apoptosis signaling is common in cancer cells and may play an important role in tumor initiation, progression and metastasis, as apoptosis normally eliminates cells with genomic damage or deregulated cell cycle, and apoptosis-deficient tumor cells are able to accumulate mutations, survive the transit in the bloodstream and grow in ectopic tissues. The ability to metastasize makes cancers hard to eradicate surgically or by localized irradiation and leads to the high death rate on cancer patients. During metastasis, cancer cells originally located in a specific tissue: a) loose their adhesion to neighboring cells in the original tissue by decreasing the expression of adhesion molecules; b) escape from the tissue of origin and burrow through tissues, through generation of proteolytic enzymes that can break down extracellular matrix, until they reach a blood vessel or a lymphatic vessel; c) enter the bloodstream by crossing the basal lamina and endothelial lining of the blood vessel wall or by crossing the wall of a lymphatic vessel that ultimately discharges its contents into the bloodstream; d) adhere to capillary walls in other tissues, extravasate and proliferate in the new environment to form metastasis at a new homing tissue, or become trapped in lymph nodes, giving rise to lymph-node metastasis. Only a tiny proportion (less than $0.1 \%$ ) of the cells released into circulation by tumors survive and succeed in founding metastatic colonies. A higher apoptosis threshold in cancer cells results in a higher survival capacity in adverse conditions and therefore, in a higher ability to metastasize, as well as in a higher resistance against therapy. Thus, resistance of cancer cells to apoptosis is especially deleterious because it enhances the malignant potential of the tumor, favoring accumulation of mutations, metastasis and rendering tumor cells resistant to therapy as well as to host defense mechanisms.

The idea of developing drugs able to induce apoptosis in tumor cells constitutes an attractive and promising approach in cancer treatment. This induction of apoptosis can be rendered through: a) direct activation of the apoptotic machinery in the tumor cell; b) induction of certain damages that can be sensed by the tumor cell to engage its own cell death; c) reestablishing or setting the capacity to undergo apoptosis following an external insult or genomic damage; d) inhibiting survival signaling in the cancer cell.

Very recent evidence indicates that the antitumor ether lipid ET-18-OCH $\mathrm{H}_{3}$ constitutes the first drug that directly activates the apoptotic signaling of tumor cells [11,12], and thereby it can constitute the leading compound of a new class of synthetic drugs targeting apoptotic machinery. 


\section{History}

In the early 1960s Herbert Fischer and Paul Gerhard Munder working at the Max-PlanckInstitut für Immunbiologie in Freiburg (Germany) on the role of macrophage activation in silicosis found that during phagocytosis of silicogenic quartz particles, phospholipase $\mathrm{A}_{2}$ was activated, leading to the generation of lysolecithin (2-lysophosphatidylcholine, LPC) and its accumulation in the macrophage cell membrane. They suggested that LPC could play a role in macrophage activation and, indeed, they found that immune adjuvants induced phospholipase $\mathrm{A}_{2}$ activation in macrophages [29,30], and small amounts of exogenous LPC strongly enhanced the phagocytic activity of peritoneal macrophages in vitro and in vivo. These results suggested that LPC could play a role in the defense mechanisms of the immune system, and prompted these authors to further study the role of LPC in the immune response. However, the naturally occurring LPC behaves as a highly active detergent [31], and thereby has a short half-life time, being biologically inactivated either by retransformation into lecithin (phosphatidylcholine, PC) through the action of acyltransferase, or by metabolization to glycerophosphocholine through the action of lysophospholipase [32] (Fig. (4)). Then, LPC analogues with longer half-life times in vivo were synthesized in the following years following a join effort of different groups led by Herbert Fisher, Otto Westphal, Hans Ulrich Weltzien and Paul Gerhard Munder in Freiburg $[2,4]$. Particular emphasis was made on changes in the positions C1 and C2 of the glycerol backbone in the molecule of LPC (1-acyl-sn-glycero-3-phosphocholine), replacing ester bonds for ether linkages in order to render analogues unable to be metabolized for either acyltransferases or lysophospholipases. Thus, some of the major changes included: i) the sn-1 ester acyl-bond was replaced by an ether alkyl-bond, with an aliphatic side chain length of 10-22 carbon atoms, which cannot be affected by lysophospholipase activity and only can be split apparently by an 1-O-alkyl-cleavage enzyme [33]; ii) The $\mathrm{OH}$ group in $s n-2$ of the molecule was transformed into a short-chain ether, such as a methoxi $\left(\mathrm{OCH}_{3}\right)$ group, preventing the acylation of the lysophospholipid to PC. As expected, some of these synthesized ether analogues of LPC turned out to be potent immune modulators [34], but surprisingly Munder and co-workers found, in the course of these studies, that some these ether lipids exerted strong antitumor activities in vitro and in vivo $[35,36]$. Munder and Westphal, using a large variety of synthetic analogues of lysolecithins, with longer half-life times in vivo, demonstrated that several of these lipid compounds selectively destroyed tumor cells [36-39]. Among the synthesized lysolecithin ether lipid analogues, 1-O-octadecyl-2-O-methyl-rac-glycero-3-phosphocholine (ET-18-OCH edelfosine) turned out to be the most effective antitumoral compound, and rapidly became the 
effective standard in trials on antitumoral activities of such ether lipids [2]. The first synthesis of ET-18-OCH $\mathrm{OCH}_{3}$ was described by Guenter Kny in 1969 [40], a chemical diploma student in O. Westphal's laboratory, making use of the previous experience of Bernd Arnold and Hans Ulrich Weltzien with the synthesis of 1-O-alkyl- and 2-O-methyl derivatives of glycerol. Among the more potentially useful compounds which were subjected to clinical trials were edelfosine (1-Ooctadecyl-2-O-methyl-rac-glycero-3-phosphocholine) and ilmofosine (1-S-hexadecyl-2methoxymethyl-2-desoxy-rac-glycero-3-phosphocholine, BM 41.440).

\section{Natural glycerol ethers}

A very close structurally related compound with $\mathrm{ET}-18-\mathrm{OCH}_{3}$ is platelet-activating factor (PAF) that plays an important role in inflammation [41-43]. The natural product PAF was identified in 1979-1980 as a 1-O-alkyl-2-acetyl-sn-glycero-3-phosphocholine [44,45], in which the alkyl group is mainly a C16 and C18 aliphatic chain, that is a decade after the synthesis of ET-18-OCH $\mathrm{O}_{3}$. Therefore, only by chance ET-18- $\mathrm{OCH}_{3}$ can be considered as a 2-O-methyl synthetic analogue of PAF. Nevertheless, PAF has no antitumor activity in vitro or in vivo, and ET-18- $\mathrm{OCH}_{3}$ does not exert significant PAF or anti-PAF activity in vivo.

Long-chain alkyl and alkenyl ethers of glycerol are known to occur in nature and are present in various animal tissues, including intestinal fat, liver, spleen, the domestic hen (particularly in the egg yolk), bone marrow and milk of cattle and man, erythrocytes [46]. Two main functions of natural glyceryl ethers have been suggested, namely as membrane components [47] and as mediators of cell responses [48]. The first indications of a naturally occurring glyceryl ether lipid of a long-chain fatty alcohol were obtained by Dorée in 1909 and Kossel and Edlbacher in 1915 in the alcohol fractions obtained from starfishes Asterias rubens and Astrospecten aurantiacus, respectively [49]. This alcohol was later shown to be batyl alcohol (31'-octadecyloxypropane-1,2-diol or 1-O-stearyl glyceryl ether) [49]. Then, a series of 1-glyceryl ethers in the nonsaponifiable fractions of liver oils of Elasmobranchs were found by Tsujimoto and Toyama in the early and mid 1920s, which were named batyl alcohol, chimyl alcohol (3-1'hexadecyloxypropane-1,2-diol or 1-O-palmityl glyceryl ether) and selachyl alcohol (3-1'octadec-9'-enyloxypropane-1,2-diol or 1-O-oleyl glyceryl ether), after the respective fish source, sea rays (Batoidei), ratfish (Chimera) and sharks (Selachoidei) [46,50]. These glyceryl ethers were also found in some marine sponges, including Stylopus australis, Tethya aurantia, Tedania ignis, Ulosa Ruetzleri, Desmapsamma anchorata [50]. It has been reported that these marine glyceryl ethers have some medicinal activities, such as an acceleration effect on blood cell 
formation in the marrow, a bacteriostatic effect, an anti-inflammatory effect, and an antitumor activity [46,51-56]. Different structures of glyceryl ethers, including terpene glyceryl ethers and macrocyclic ether lipids have been also found in microorganisms, such as the extreme halophile Halobacterium cutirubrum and archaebacteria, which exhibit unusual resistance to adverse environmental conditions [57,58]. Fecapentaenes, polyunsaturated glyceryl ethers [59] produced by Bacteroides species present in the lumen of the human colon and present in the feces, have been suggested to be mutagens and colon carcinogens [60,61].

Ether-linked species are also important contributors to both choline and ethanolamine glycerophospholipids in mammalian tissues. In most tissues, the predominant ether-linked choline phospholipid species is plasmanylcholine (1-O-alkyl-2-acyl-sn-glycero-3phosphocholine) while plasmenylethanolamine (1-O-alk-1'-enyl-2-acyl-sn-glycero-3phosphoethanolamine) is the primary ether-linked ethanolamine phospholipid species. A notable exception to this is heart from several species (except rat) and bovine spermatozoa in which 33$52 \%$ and about $63 \%$ of the PC, respectively, is in the plasmenyl form [62,63]. High levels of alkyl and alk-1-enyl moieties in both choline and ethanolamine glycerophospholipids occur in human neutrophils [64]. Those glycerophospholipids with alk-1-enyl (plasmenyl or vinyl ether, that is a cis double bond adjacent to the ether linkage) groups at the sn-1 position of the glycerol backbone are referred to as plasmalogens (i.e. choline plasmalogens and ethanolamine plasmalogens). To date, the physiological role of plasmalogens is not clear, although various important functions have been suggested, such as modulation of membrane fluidity and phase transition temperature [65], protection against oxidative stress [66], participation in signal transduction processes [48,67], and facilitation of membrane fusion [68] and membrane trafficking [69]. It has also been suggested that plasmalogens function as a reservoir for polyunsaturated fatty acids [70,71] which, when released by a calcium-independent, plasmalogen-specific phospholipase $\mathrm{A}_{2}\left(\mathrm{PLA}_{2}\right)$ [72-74], form bioactive molecules, such as prostaglandins and leukotrienes. In this regard, plasmenylethanolamines are a major storage depot for arachidonic acid [75,76]. Moreover, the lysoplasmalogens generated from ethanolamine plasmalogens via $\mathrm{PLA}_{2}$ hydrolysis can induce the biosynthesis of the potent lipid mediator PAF, through CoA-independent transacylases [77-80].

Interestingly, plasmenylcholine analogues of the antitumor ether lipid ET-18- $\mathrm{OCH}_{3}$, incorporating a cis-O-vinyl linkage into the sn-1 position of the glycerol backbone, have been synthesized very recently and show an antiproliferative effect in tumor cell lines in vitro [20,21]. 


\section{Cellular uptake}

There is a strong correlation between the cellular uptake of ET-18- $\mathrm{OCH}_{3}$ and the cytotoxic ability of the drug [11,12,81-85]. Unlike tumor cells, normal cells are unable to take up significant amounts of the ether lipid [11,12]. We have recently demonstrated by combining microinjection and in situ DNA fragmentation assays that incorporation of ET-18-OCH $\mathrm{H}_{3}$ into the cell is a necessary requirement for ET-18- $\mathrm{OCH}_{3}$-induced apoptosis, and normal cells are spared because they are not able to incorporate enough amounts of the ether lipid [12]. Thus, a primary culture of normal human fibroblasts did not incorporate significant amounts of $\left[{ }^{3} \mathrm{H}\right] \mathrm{ET}-18-\mathrm{OCH}_{3}$ even after long-term incubations (more than $72 \mathrm{~h}$ ) and were resistant to the apoptotic action of the ether lipid, but microinjection of the ether lipid into these normal cells prompted rapid apoptosis [12]. These data demonstrate that incorporation of $\mathrm{ET}-18-\mathrm{OCH}_{3}$ into the cell is a crucial event in the selective apoptotic action of the ether lipid on tumor cells. These experiments also indicate that the cell membrane acts as a barrier to ET-18- $\mathrm{OCH}_{3}$ in normal cells. Furthermore, we found that microinjected ET-18- $\mathrm{OCH}_{3}$ induced apoptosis in a dose-response pattern [12], suggesting that a threshold for intracellular ET-18-OCH $\mathrm{H}_{3}$ concentration must be reached in order to trigger apoptosis.

The amount of ET-18- $\mathrm{OCH}_{3}$ incorporated into the cell plays an important role in determining the cytotoxicity of $\mathrm{ET}-18-\mathrm{OCH}_{3}$, and the number of drug molecules per cell is a critical determinant of the cytotoxicity of ET-18- $\mathrm{OCH}_{3}$. The cell density may determine the "effective" exposure dose in that the drug is diluted among more cells. Therefore, exposure dose and cell density are important parameters in determining the killing effect induced by ET-18$\mathrm{OCH}_{3}$ [83]. In addition to drug dose and cell density, there are more variables that affect ether lipid uptake. Thus, cellular incorporation of $\mathrm{ET}-18-\mathrm{OCH}_{3}$ depends on the cell type, percent of serum proteins in the assay, temperature, etc.

Although ether lipid uptake is of pivotal importance for the biological action of ET-18$\mathrm{OCH}_{3}$, conflicting data have been reported in order to explain how this ether lipid is incorporated. Although no conclusive notion has been reached, direct adsorption onto the plasma membrane followed by passive diffusion, endocytosis, lipid flip-flop, and a specific proteindirected incorporation have been postulated for ET-18-OCH $\mathrm{CH}_{3}$ uptake.

AEPs do not directly interact with DNA, but due to their phospholipid nature they are readily incorporated into cellular membranes [86-89]. Lysophospholipids have a high monomer concentration (e.g., the critical micelle concentration of 1-palmitoyl glycerophosphocholine is 7 x $\left.10^{-6} \mathrm{M}\right)$ and are inserted spontaneously into synthetic bilayers [90,91]. This can be also the 
mechanism of ET-18- $\mathrm{OCH}_{3}$ membrane association as it is a lysophospholipid analogue. In fact, ET-18- $\mathrm{OCH}_{3}$ has been reported to be incorporated into various tumor cell membranes to the extent that accounted on for up to $17 \%$ of the purified membrane phospholipids of the membranes [88]. Three major steps must be considered in the uptake of a lipid: a) association with the plasma membrane; b) internalization; and c) metabolism. ET-18- $\mathrm{OCH}_{3}$ is not significantly metabolized (see below) and can interact with the plasma membrane of both sensitive and resistant cells in a similar non-specific way. Thus, $\left[{ }^{3} \mathrm{H}\right] \mathrm{ET}-18-\mathrm{OCH}_{3}$ bound in similar amounts to both resistant and sensitive cells [84] at low temperatures $\left(4^{\circ} \mathrm{C}\right)$ when cellular processes, such as membrane internalization or possible protein-facilitated transbilayer movement are greatly slowed or stopped, suggesting that ether lipids tend to interact unspecifically with membranes. However, when cells were warmed at room temperature to allow internalization processes to become active, about $80 \%$ of the pre-bound $\mathrm{ET}-18-\mathrm{OCH}_{3}$ was internalized in sensitive cells, while only $10-20 \%$ of pre-bound ether lipid was taken up by resistant cells [84]. On these grounds, cellular uptake of this antitumor drug seems to be dependent on an internalization process. Internalized lipid (uptake) can be readily evaluated through extensive washing of the cells in either serum- or bovine serum albumin (BSA)containing medium [92], in order to remove ET-18- $\mathrm{OCH}_{3}$ remaining on the cell surface due to the ability of the ether lipid to interact with BSA and serum proteins. Internalized ET-18-OCH is unavailable to BSA and therefore cannot be removed, but loosely membrane bound ether lipid can be washed off. This is due to the fact that $\mathrm{ET}-18-\mathrm{OCH}_{3}$ has the similar high affinity binding to serum albumin as also described for natural LPC [81,93].

It has been reported that inhibition of endocytosis by a number of agents (chloroquine, monensin, vinblastine) inhibited both the cell-killing effect and the uptake of ET-18- $\mathrm{OCH}_{3}$ in drug-sensitive leukemic cells [94], suggesting that endocytosis was a major route for ET-18$\mathrm{OCH}_{3}$ uptake. However, ET-18-OCH 3 uptake by drug-sensitive cell lines has been shown to be unaffected by metabolic inhibitors of ATP biosynthesis, suggesting that ET-18-OCH $\mathrm{O}_{3}$ uptake did not occur via endocytosis, and it did not depend apparently on cellular energy [81]. Although most of the uptake studies have been carried out in the presence of $10 \%$ fetal calf serum (FCS) in the culture medium, that can affect lipid uptake, short time unidirectional ET-18-OCH $\mathrm{Optake}_{3}$ studies have been also carried out in serum-free medium in order to avoid the confounding effect of binding to serum components. Under these conditions ET-18-OCH $\mathrm{H}_{3}$ uptake in $\mathrm{L} 1210$ murine leukemia cells was found non-saturable and was not affected by the metabolic inhibitors choroquine, monensin or cytochalasin B, that are known inhibitors of endocytosis [95]. ET-18- 
$\mathrm{OCH}_{3}$ binds to serum proteins, primarily albumin and high density lipoprotein (HDL). A study indicates that the majority of the ether lipid (71\%) is bound to albumin and about 6\% to HDL [96], whereas another study reports that ET-18- $\mathrm{OCH}_{3}$ binds to both albumin and HDL in about similar proportions (40\%) [95]. Therefore this protein binding reduces the extracellular concentration of free drug and the cellular uptake of ET-18-OCH 3 . In this regard, addition of serum to the incubation medium inhibits the cytotoxicity of AEPs in a concentration-dependent manner [95,97,98, Gajate, C. and Mollinedo, F., unpublished data], and this is likely related to reduced uptake. Addition of human serum or human albumin reduced uptake by approximately $50 \%$ at levels as low as $0.5-1 \%$ serum or albumin [93]. Uptake has been reported to be reduced at $23^{\circ} \mathrm{C}$ as compared to $37^{\circ} \mathrm{C}$, reaching a steady-state level of approximately $50 \%$ of the values for $37^{\circ} \mathrm{C}$, and the uptake was still lower at $0^{\circ} \mathrm{C}$, reaching a plateau about $50 \%$ lower than at $23^{\circ} \mathrm{C}$ [93]. These data in serum-free medium suggested a non-saturable, energy independent and moderately temperature sensitive drug uptake that can be compatible with a passive diffusion mechanism [93]. The lipidic nature of ET-18-OCH 3 and its rather low molecular weight (mw = 524) would also agree with a passive diffusion mechanism, as lipophilicity and molecular weight are major determinants of diffusion. A plausible mechanism could be that the ether lipid might be incorporated directly into the plasma membrane by passive diffusion and then internalized by flip-flop to the cytoplasmic face of the bilayer or by other non-energy-dependent mechanisms $[95,99]$. However, because flip-flop is inherently slow and ET-18-OCH $\mathrm{OCH}_{3}$ uptake follows a rapid kinetics, the assistance of a transmembrane transporter would be likely required. The putative participation of transporters, that play a role in the maintenance or dissipation of transbilayer lipid asymmetry, in ET-18- $\mathrm{OCH}_{3}$ uptake remains to be analyzed. These transporters can be divided into three classes, based on the direction of transport of the lipid substrate: a) "scramblases", which facilitate the bi-directional movement of lipids across the bilayer; b) "flippases", which catalyze the cytofacially directed transport of lipids; and c) "floppases", which promote the movement of lipids from the cytoplasmic to the external face of the membrane [100]. The demonstration that MDR1 and MDR3 P-glycoproteins function as PC translocators [101] raises the possibility that lipid transporters can play a role in ET-18-OCH uptake or extrusion. In this regard, it has been reported that the PC analogue ET-18-OCH $\mathrm{OH}_{3}$ a substrate for class I and class II P-glycoproteins and other ABC transporters, that mediate pleiotropic drug resistance in a wide range of organisms [102]. Also, because ET-18-OCH binds $_{3}$ to albumin and HDL in serum, it could also be suggested that albumin and HDL anchor on the 
cell surface of distinct cells and deliver bound ether lipid gradually, since both albumin and HDL can interact to specific saturable sites on the cell surface releasing selected ligands $[103,104]$.

In spite of controversial experimental support, endocytosis or passive diffusion do not explain the general observation that ET-18- $\mathrm{OCH}_{3}$-sensitive cells take up significant amounts of the ether lipid while resistant cells do not. In this regard, flow cytometry analysis with fluorescein-labeled albumin showed no correlation between endocytosis and ET-18-OCH uptake [11]. Furthermore, Zoeller and co-workers [84], using ethyl methanesulfonate as mutagen [105], isolated mutant strains from the murine, macrophage-like cell line RAW 264.7, that were resistant to the cytotoxic effect of $\mathrm{ET}-18-\mathrm{OCH}_{3}$, and found no differences in both receptormediated and fluid-phase endocytosis between ET-18-OCH$-\mathrm{CH}_{3}$-resistant mutants and the ET-18$\mathrm{OCH}_{3}$-sensitive parent cells, whereas the parent cells took up significant amounts of ET-18$\mathrm{OCH}_{3}$ and the mutant cells did not. Thus, ET-18-OCH 3 appears to be taken up through a more specific process than general endocytosis. Interestingly, hybrids generated from the fusion of ET-18-OCH 3 -uptake RAW competent cells with the uptake-deficient RAW mutants were able to take up ET-18- $\mathrm{OCH}_{3}$ in similar proportions as the uptake competent cells, suggesting that the mutations associated with these mutants are recessive [84].

It has been found that suramin, a broad-specificity membrane impermeable inhibitor of ligand-receptor interactions [106-111] inhibited both ET-18-OCH $\mathrm{CH}_{3}$ uptake and ET-18-OCH induced apoptosis in human leukemic cells [11], suggesting that ET-18-OCH 3 can interact with a cell surface protein involved in the transport of the ether lipid inside the cell. As ET-18-OCH $\mathrm{OH}_{3}$ taken up by tumor cells at much higher levels than normal cells, it could be envisaged that a cellular structure, absent or present in low basal amounts in normal cells, but synthesized in higher amounts or appropriately modified in tumor cells, is responsible for the ET-18-OCH uptake. It is interesting to note that there is no efflux of ET-18- $\mathrm{OCH}_{3}$ from preloaded cells, suggesting a tight association of the drug with cellular structures inside the cell [95]. In this regard, a very recent report indicates that a photoactivatable analogue of $\mathrm{ET}-18-\mathrm{OCH}_{3}$ is able to interact with two cytosolic proteins of MCF-7 human breast cancer cells of molecular masses of 47 and $170 \mathrm{kDa}[112]$.

Binding assays with the ether lipid ET-18- $\mathrm{OCH}_{3}$ are complicated by the unspecific binding of the ether lipid to membrane that might hamper the detection of a putative specific binding to a hypothetical receptor or transporter, which could be ultimately related to the triggering of the biological activities of $\mathrm{ET}-18-\mathrm{OCH}_{3}$. This problem is inherent to the lipidic nature of ET-18- $\mathrm{OCH}_{3}$. Thus, binding assays with the structural-closely related PAF molecule 
are rather problematic due to a high unspecific binding [113], despite that PAF is well known to exert its biological effects through its interaction with a specific receptor [114]. Because of its structural similarity with PAF, the possibility that ET-18- $\mathrm{OCH}_{3}$ might enter cells and act via the PAF receptor might be discussed. However, ET-18- $\mathrm{OCH}_{3}$ uptake and cytotoxicity proceed via a mechanism independent of the interaction of ET-18- $\mathrm{OCH}_{3}$ with a PAF receptor. The evidence for this is manifold:

a) ET-18-OCH 3 is active and is incorporated by cells devoid of PAF receptors, such as HL-60 cells [11]. Interestingly, PAF receptors develop following granulocytic differentiation of HL-60 cells [115,116], when these cells become resistant to the ether lipid and do not incorporate the drug [11,82,117,118].

b) Lack of correlation between the presence of PAF receptor and ET-18- $-\mathrm{OCH}_{3}$ uptake and cytotoxicity [11,117-119].

c) Neither PAF nor PAF antagonists prevent ET-18- $-\mathrm{OCH}_{3}$ uptake and cytotoxicity [11,118-120].

d) PAF does not induce apoptosis in ET-18- $\mathrm{OCH}_{3}$ sensitive cells $[11,118]$.

e) The affinity of the PAF receptor for ET-18- $\mathrm{OCH}_{3}$ was about 5000 times smaller than for the natural PAF lipid [118].

We favor the notion that a still unidentified cell surface protein can be involved in the specific incorporation of ET-18- $\mathrm{OCH}_{3}$ into target cells. This putative protein should be either expressed or modified selectively in transformed cells. Thus, non-transformed 3T3 cells were resistant to the apoptotic action of ET-18- $\mathrm{OCH}_{3}$ and incorporated only small amounts of the ether lipid, while upon transformation with SV40, these cells became sensitive to ET-18-OCH and incorporated high amounts of the lipid [11]. Likewise, human leukemic HL-60 cells incorporate high amounts of $\mathrm{ET}-18-\mathrm{OCH}_{3}$ and are sensitive to its apoptotic action, whereas following dimethyl sulfoxide (DMSO) treatment HL-60 cells are differentiated towards cells with features of normal non-transformed mature neutrophils [121], and in this differentiated state the uptake of the ether lipid was decreased as well as the sensitivity to the drug $[11,82,117,118]$. These data indicate that the action of the ether lipid is specific for tumor cells and that both cellular uptake and ET-18- $\mathrm{OCH}_{3}$-induced apoptosis are dependent on the malignant state of the cells (Fig. (5)).

ET-18-OCH $\mathrm{OH}_{3}$ preferentially accumulates in the plasma membrane of transformed cells [88,122,123]. Taken together, the data support a putative ether lipid uptake mechanism consisting in two steps: a) ET-18- $\mathrm{OCH}_{3}$ binds first in a rather unspecific way to the outer layer of 
the plasma membrane from which can be washed off by repeated washings or by BSA extraction; b) the ether lipid is flipped across the plasma membrane, being translocated into the cytoplasmic leaflet of the lipid bilayer, through still unidentified inwardly directed transporters or flippases.

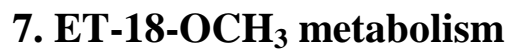

ET-18- $\mathrm{OCH}_{3}$ is a very metabolically stable compound, in comparison with its natural counterparts alkyl-lyso-phosphatitdylcholine and PAF. In tumor cells in culture, 98\% of ET-18$\mathrm{OCH}_{3}$ remained unmodified after 24-h incubation [124]. Theoretically, ET-18-OCH 3 , as an alkyl-ether-phospholipid, can be metabolized through three major pathways (Fig. (6)): i) cleavage of the alkyl group, with formation of 1-lyso-2-O-methyl-phospholipid and stearyl alcohol; ii) phospholipase C (PLC) hydrolysis, with formation of 1-O-alkyl-2-O-methylglycerol and phosphocholine; and iii) phospholipase D (PLD) hydrolysis, with formation of 1-O-alkyl-2$O$-methyl-phosphatidic acid and choline. However, the ether lipid is not a substrate for PLA $\mathrm{A}_{2}$ due to the ether alkyl bond in C2.

In 1964, Tietz, Lindberg and Kennedy [125] discovered an enzyme termed glyceryl-ether monooxygenase, which has been also named $O$-alkyl glycerol monooxygenase, 1 - $O$-alkylcleavage enzyme, glyceryl etherase, glyceryl ether hydroxylase, or glyceryl ether oxidase. It is a membrane-bound protein that specifically cleaves the ether bond in glyceryl ethers. The enzyme inserts one oxygen atom of an oxygen molecule into the glyceryl ether substrate, hydroxylating the $\alpha$-carbon atom of the lipid carbon chain, and subsequently cleaving the $O$-alkyl bond to the glycerol moiety and the respective aliphatic alcohol. Since high levels of glyceryl ethers are toxic to some cells, the glyceryl-ether monooxygenase plays an important role in regulating the levels of these ethers. In tissues in which the ether levels are low, as in human liver, the glyceryl-ether monooxygenase levels are high. Because ET-18- $\mathrm{OCH}_{3}$ exerts selective effects on tumor cells, attempts were made to explain this selectivity by a higher degradation of the ether lipid in normal cells. This notion was supported by the finding that some neoplastic tissues were found to have low levels of the glyceryl-ether monooxygenase [33]. However, it soon turned out no correlation between sensitivity of the cells to AEPs and activity of this enzyme [126,127]. Now, it is widely accepted that $\mathrm{ET}-18-\mathrm{OCH}_{3}$ is not metabolized in most cells by glyceryl-ether monooxygenase [128,129], but appears to be metabolized very slowly by PLC activity to produce 1-O-octadecyl-2-O-methyl-rac-glycerol (OMG) [87,127,130-132]. This latter metabolite could also be generated by the action of a PLD activity followed by phosphatidate 
phosphohydrolase, like occurring with natural phospholipids [124,133], and it has been found that PLD activity participates also in the metabolism of ET-18- $\mathrm{OCH}_{3}$ [124]. It has been hypothesized that the OMG metabolite, found in trace amounts in tumor cells, could be responsible for the cytotoxic action of $\mathrm{ET}-18-\mathrm{OCH}_{3}$, due in part to the protein kinase (PKC) inhibitory action of OMG [131]. However, this notion is not sustainable at all, since: i) metabolism of ET-18- $\mathrm{OCH}_{3}$ by PLC or by PLD/phosphatidate phosphohydrolase occurs only at very low rates (less than $2 \%$ after 24 -h incubation), if at all, in both tumor epithelial and leukemic cells [87,117,127,130-132,134]; ii) OMG does not exert antitumor activity by itself on leukemic cells in vivo or in vitro $[11,117,133,135]$; iii) lack of correlation between the quantity

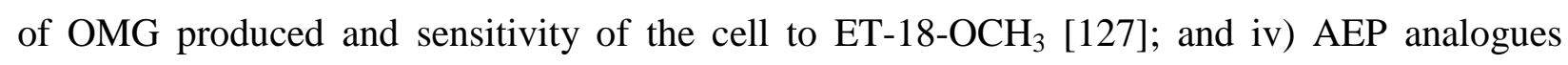
unable to be metabolized by PLC are effective anticancer agents [134,136,137]. All of the above evidences also argue against metabolism being an obligatory step in the antiproliferative and cytotoxic effects of ET-18-OCH . In this regard, in several cell lines, there is no correlation between the extent of metabolism of ET-18- $\mathrm{OCH}_{3}$ and susceptibility to its growth-inhibitory and cytotoxic effects [127]. Also, ET-18-OCH 3 metabolism was negligible in human leukemic HL60 and K562 cells (1-2\%) or in human colon carcinoma HT29 cells (2.5\%) [124]. Taken together, these data indicate that $\mathrm{ET}-18-\mathrm{OCH}_{3}$ is active per se and not a prodrug.

Ether lipids show high specific cytotoxicity in vitro on a wide variety of experimental tumors, but only moderate activity in vivo. One reason for this lack of activity in the whole animal might be a high degree of metabolic degradation in vivo. In this regard, some metabolism has been suggested to be present in vivo, as very little of the intact compound was eliminated with urine and feces, and very low levels were found in tissues [138]. A reduced metabolic turnover and thus a slight enrichment of ET-18- $\mathrm{OCH}_{3}$ was found in tumor tissue in in vivo assays [139]. Unlike tumor cells, cultured rat hepatocytes, however, can degrade ET-18-OCH , and about $35 \%$ and $59 \%$ of total radiolabeled $\left[{ }^{3} \mathrm{H}\right] \mathrm{ET}-18-\mathrm{OCH}_{3}$ was metabolized by liver cells after 6 and $24 \mathrm{~h}$ incubation, respectively [124]. A variety of labeled metabolic products of ET-18-OCH were found, including 1-O-alkyl-2-O-methyl-phosphatidic acid > 1-O-alkyl-2-O-methyl-glycerol $>$ stearyl alcohol, as products of direct metabolism through the action of the enzymes depicted in Fig. (6), and phosphatidylcholine > triglycerides > fatty acids, as products of secondary metabolism [124]. Only very low amounts of stearoyl glycerol $(0.9 \%)$, the direct product of the action of glyceryl-ether monooxygenase on $\mathrm{ET}-18-\mathrm{OCH}_{3}$, was recovered in hepatocytes, suggesting that this is a minor metabolic route in the ET-18- $\mathrm{OCH}_{3}$ metabolism in hepatocytes. Taken together, the current data indicate that $\mathrm{ET}-18-\mathrm{OCH}_{3}$ is not a substrate for glyceryl-ether 
monooxygenase, and only negligible amounts of the metabolic product generated by this metabolic route are found in hepatocytes. Thus, the metabolism of ET-18-OCH 3 is basically due to the action of PLC and PLD activities. Because phospholipases C and D are abundant not only in liver, but also in other tissues and cell types (lung, heart, leukocytes, etc.) [140-143], they might contribute to the degradation of ET-18- $\mathrm{OCH}_{3}$ given systemically.

\section{Antitumor activity}

ET-18- $\mathrm{OCH}_{3}$ shows an antitumor effect both in vitro and in vivo, and is considered as a standard and prototype for other ATLs with similar antineoplastic activities. The antitumor effect of ET-18- $\mathrm{OCH}_{3}$ is based mainly on two different mechanisms which can act synergistically against neoplastic growth. ET-18- $\mathrm{OCH}_{3}$ enhances the tumoricidal activity of macrophages [144,145], and exerts a direct cystostatic and cytotoxic effect on tumor cells [9-11,146-150]. However, the direct cytotoxicity effect of ET-18- $\mathrm{OCH}_{3}$ seems to be the major action for its antitumor activity in vivo, and the proapoptotic effect of ET-18- $\mathrm{OCH}_{3}$ accounts for the cytotoxic activity of the ether lipid [9-11,150]. This combination of a stimulatory effect on host defense cells and a direct destructive effect on neoplastic cells in one molecule makes ET-18-OCH $\mathrm{O}_{3}$ a potentially effective antitumor drug. The cytotoxicity of ET-18-OCH 3 is believed to occur independently and by a different mechanism from the cytostatic effects of the drug [148,149]. In addition to potentiate host defenses against tumor, ET-18-OCH 3 has been reported to affect four major parameters that make this AEP a potentially potent antitumor drug, namely (Figure (7)): a) inhibition of tumor cell proliferation; b) induction of apoptosis in tumor cells; b) inhibition of metastasis; d) inhibition of angiogenesis. Also, ET-18- $\mathrm{OCH}_{3}$-induced differentiation has been reported in some tumor models that could be important for the so named differentiation therapy. Nevertheless, whereas the cytostatic and proapoptotic effects of ET-18-OCH $\mathrm{H}_{3}$ are well established, its role in modulating metastasis and differentiation is questionable at present.

\subsection{Inhibition of proliferation and cell cycle effects}

ET-18- $\mathrm{OCH}_{3}$ treatment does not interfere with the S phase of the cell cycle, but leads to the accumulation of cells in $\mathrm{G}_{2} / \mathrm{M}$ [148,151-156]. ET-18-OCH 3 inhibits cell division without concurrent inhibition of nuclear division, leading to multinucleate cell formation, and subsequent cell death through apoptosis [157,Mollinedo, F., del Canto-Jañez, E., Verhaegen, S. and Gajate, C., unpublished data]. ET-18-OCH 3 -treated cells proceeded through the full cell cycle, but failed to undergo cell division (mitosis), and instead accumulated as tetraploid or octaploid cells in the 
$\mathrm{G}_{0} / \mathrm{G}_{1}$ phase of the cell cycle [157,Mollinedo, F., del Canto-Jañez, E., Verhaegen, S. and Gajate, C., unpublished data]. Inhibition of cell growth by ET-18- $\mathrm{OCH}_{3}$ resulted from inhibition of cytokinesis [157,Mollinedo, F., del Canto-Jañez, E., Verhaegen, S. and Gajate, C., unpublished data]. Also, a number of reports show that ET-18-OCH $\mathrm{H}_{3}$-treated cells are arrested in the $\mathrm{G}_{0} / \mathrm{G}_{1}$ phase of the cell cycle $[148,153,154,157]$. It has been reported that ET-18-OCH $\mathrm{OCH}_{3}$ inhibits PC synthesis $[39,158]$ that arises from the inhibition of CTP:phosphocholine cytidylyltransferase (CCT) [159]. The addition of LPC provided an exogenous source of cellular phospholipid, restoring PC de novo biosynthesis [159] (see below), and partially reduced the number of apoptotic cells following ET-18-OCH 3 treatment [157]. Boggs and co-workers [148] found that LPC addition prevented ET-18- $\mathrm{OCH}_{3}$-dependent accumulation of cells in $\mathrm{G}_{2} / \mathrm{M}$ and the subsequent apoptotic response. However, LPC did not overcome the ET-18-OCH $\mathrm{G}_{0} / \mathrm{G}_{1}$ block, although the growth-arrested cells remained viable, indicating that restoring of PC synthesis by supplementation with LPC overrides the cytotoxic but not the cytostatic activity of

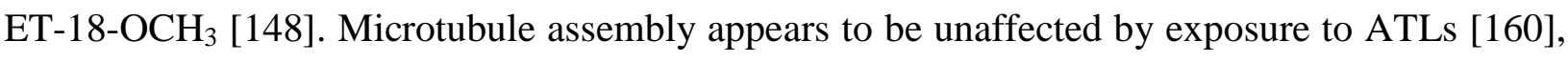
although F-actin filaments could be collapsed [4,157]. At present, the mechanisms by which ET18- $\mathrm{OCH}_{3}$ arrests cell cycle progression and inhibits cytokinesis have yet to be explored in detail.

\subsection{Induction of apoptosis}

A key finding in the elucidation of the processes involved in the antineoplastic effect of ET-18-OCH $\mathrm{OCH}_{3}$ was the demonstration in 1993 by Mollinedo and co-workers [9] in Madrid (Spain) and Diomede and co-workers [10] in Milan (Italy) of its proapoptotic effect on cancer cells. This apoptotic action appears to be the major antitumor effect of ET-18- $\mathrm{OCH}_{3}[9,10,11,150]$. The apoptotic response was optimally induced after treatment with 3-5 $\mu \mathrm{g} / \mathrm{ml}(6-10 \mu \mathrm{M})$ of ET-18$\mathrm{OCH}_{3}$ [164]. Following these pioneering studies, subsequent reports have shown that other ATLs are also able to induce an apoptotic response in tumor cells $[19,161,162]$. We have also found that ET-18-OCH $\mathrm{OH}_{3}$ is a potent inducer of apoptosis in cancer cells, but spares normal cells [11]. Based on our own data on the molecular mechanisms by which ET-18- $\mathrm{OCH}_{3}$ engages selectively the suicide apparatus, we propose a two-step model for the proapoptotic action of ET-18-OCH on cancer cells that represents a new mechanism of action for an antitumor drug (Fig. (8)). A first and crucial event is the selective incorporation of ET-18-OCH 3 into the target tumor cell, and we hypothesize that a yet unidentified cell surface protein present or appropriately modified in cancer cells, but not in normal cells, would be responsible for the selective incorporation of the ether lipid into the malignant cell $[11,12]$. Then, ET-18- $\mathrm{OCH}_{3}$ stimulates from inside the cell 
a cell death receptor Fas/CD95-mediated apoptotic signaling pathway to induce apoptosis, independently of the natural ligand FasL. This second step requires the presence of the cell death receptor Fas/CD95 and is not selective for cancer cells, as ET-18-OCH$-\mathrm{CH}_{3}$-microinjected normal human fibroblasts undergo apoptosis [12]. Thus, the apoptotic action of ET-18- $\mathrm{OCH}_{3}$ appears to take advantage of some plasma membrane components uniquely expressed or modified in the cell surface of transformed cells as well as of the efficient Fas cell death signaling route present in both cancer and normal cells. The above model is based on the following evidences [11,12,112,162]: a) cancer cells take up significant amounts of the ether lipid, but normal cells do not; b) disruption of ligand-receptor interactions by suramin treatment inhibits both ET-18$\mathrm{OCH}_{3}$ uptake and cytotoxicity; c) ET-18-OCH 3 is able to interact with cellular proteins; d) ET$18-\mathrm{OCH}_{3}$ does not induce apoptosis in normal fibroblasts, which are unable to incorporate the drug, but these cells rapidly undergo apoptosis following microinjection of the ether lipid; e) ET18- $\mathrm{OCH}_{3}$ only induces apoptosis in Fas/CD95-containing cells; f) Fas/CD95-deficient cells are spared from the apoptotic effect of ET-18- $\mathrm{OCH}_{3}$, but they become sensitive to the apoptotic action of the ether lipid after transfection with Fas; g) Fas/CD95-expressing cells that do not take up ET-18- $\mathrm{OCH}_{3}$ are unaffected by the ether lipid when this is added exogenously, but they undergo rapid apoptosis following microinjection of ET-18-OCH $\mathrm{H}_{3}$; h) clustering and capping of Fas is rapidly observed following $\mathrm{ET}-18-\mathrm{OCH}_{3}$ treatment and takes place before the onset of DNA fragmentation. A recent report also supports the participation of Fas/CD95 in the mechanism of action of ATL analogues, involving a Fas-FADD-mediated signaling pathway [163]. The clustering, capping and subsequent activation of Fas/CD95, independently of FasL, by intracellular ET-18- $\mathrm{OCH}_{3}$ represents a novel mechanism of action for an antitumor drug. Thus, two main requirements must be fulfilled in order to elicit an apoptotic response upon ET18- $\mathrm{OCH}_{3}$ ether lipid treatment, namely: a) ether lipid uptake, and b) Fas/CD95 presence in the target cell. Cells that fail to accomplish efficiently one or both requirements are unable to undergo apoptosis upon ET-18- $\mathrm{OCH}_{3}$ treatment. Normal cells are resistant to the ether lipid action due to their inability to incorporate enough amounts of ET-18-OCH $\mathrm{CH}_{3}$ required to induce apoptosis, whereas a wide number of cancer cells incorporate high amounts of this ether lipid [12]. Cells that do not express Fas/CD95 fail to undergo apoptosis after incubation or microinjection with ET-18- $\mathrm{OCH}_{3}$, in spite of achieving high intracellular concentrations of the ether lipid [12]. Cells expressing Fas/CD95 at their cell surface, but unable to take up the ether lipid, are resistant to undergo apoptosis upon exogenous addition of ET-18- $\mathrm{OCH}_{3}$, but become sensitive to the drug when the ether lipid is microinjected [12]. This indicates that an interaction 
between ET-18-OCH 3 and Fas/CD95 at the external side of the cell surface is not involved in the onset of the ether lipid-induced apoptosis and that $\mathrm{ET}-18-\mathrm{OCH}_{3}$ must be incorporated into the cell to trigger a Fas/CD95-mediated apoptotic response.

In recent studies from our and other groups [164-167], a number of additional apoptotic signaling pathways have been implicated in the apoptotic response elicited by ET-18-OCH including: persistent activation of c-Jun $\mathrm{NH}_{2}$-terminal kinase (JNK), disruption of the mitochondrial transmembrane potential $\left(\Delta \Psi_{\mathrm{m}}\right)$, release of cytochrome $c$ from mitochondria, caspase-3 activation. ET-18- $\mathrm{OCH}_{3}$ is also able to induce the expression of fos and jun protooncogenes and to activate the transcription factor AP-1 in human leukemic cells [164,168]. We have observed that the steady state mRNA level of $c$-jun was dramatically increased on ET-18$\mathrm{OCH}_{3}$ treatment [168]. Antisense oligonucleotides directed against c-jun blocked ET-18-OCHinduced apoptosis, indicating a role for c-Jun in this apoptotic response [164]. This notion was further confirmed using a dominant-negative mutant of c-jun that inhibited ET-18- $\mathrm{OCH}_{3}$ induced apoptosis [166]. The role of c-Jun in the cascade of events triggered by ET-18-OCH remains to be elucidated. C-Jun is a major component of the transcription factor AP-1, but because ET-18- $\mathrm{OCH}_{3}$-induced apoptosis does not require protein synthesis [165], it can be envisaged the involvement of c-Jun in transcription-independent events leading to cell death. The weak induction of c-fos by $\mathrm{ET}-18-\mathrm{OCH}_{3}$ was not related to the induction of apoptosis, as antisense oligonucleotides against c-fos did not prevent ET-18-OCH $\mathrm{CH}_{3}$-induced apoptosis [164]. This is in agreement with evidence from c-Fos-deficient mice demonstrating that c-fos is not essential for the induction of apoptosis [169]. We have also found that ectopic overexpression of $b c l-2$ or $b c l-x_{L}$ prevents apoptosis induced by $\mathrm{ET}-18-\mathrm{OCH}_{3}$, but not its cellular uptake [11], suggesting that high levels of $\mathrm{Bcl}-2$ and $\mathrm{Bcl}-\mathrm{X}_{\mathrm{L}}$ can block the intracellular signaling route leading to cell death triggered by ET-18- $\mathrm{OCH}_{3}$. However, p53 is dispensable for ET-18-OCHinduced apoptosis as HL-60 cells are very sensitive to the apoptotic action of ET-18-OCH $[9,11]$ and do not express p53 [170]. On the other hand, the apoptotic effect of ET-18-OCH $\mathrm{OCH}_{3}$ not related to rapid changes in cytosolic free calcium concentration [118].

\subsection{Antiangiogenic effect}

In the early 1970s, Folkman proposed antiangiogenic therapy as a method to block tumor growth [171,172], and subsequent research evidenced that neovascularization plays an important role in the growth and spread of tumors. There is now strong evidence that inhibition of 
angiogenesis can severely restrict tumor growth and can be an interesting approach to cancer treatment [172-174].

Using the human microvascular endothelial cell line HMEC-1 [175], Candal and coworkers [176] found that ET-18-OCH 3 reversibly inhibited formation of HMEC-1 tubules, used as an in vitro assay for angiogenesis. This antiangiogenic activity was shown at doses higher than 43 nM. ET-18- $\mathrm{OCH}_{3}$ exerted additional effects on HMEC-1 when used at lower concentrations (32 nM), namely [176]: a) a decrease in the expression of several known adhesion molecules, including: integrin beta-1 (CD29), involved in wound healing, tissue invasion and tumor metastasis; CD44 (HCAM, homing-associated cell adhesion molecule), involved in lymphocyte homing; and CD54 (ICAM-1, intercellular adhesion molecule-1), involved in neutrophil transmigration and the inflammatory response; b) a decrease in the cell-to-cell tight association. ET-18- $\mathrm{OCH}_{3}$ was also found to inhibit in vitro the ability of bovine adrenal capillary endothelial cells to migrate toward the angiogenic agent basic fibroblastic growth factor (bFGF), using a Boyden chamber assay [177]. This in vitro antiangiogenic activity was detected at ether lipid doses ranging between 8-200 nM, however ET-18- $\mathrm{OCH}_{3}$ enhanced by itself microvascularcell migration when used at doses higher than $200 \mathrm{nM}$. Such biphasic effects have also been reported for some inhibitors of angiogenesis, like thrombospondin [178], likely due to the capacity of thrombospondin to stimulate multiple receptors with differing affinities, some inhibitory and some stimulatory. The visualization of neovascularization in vivo, in corneas receiving bFGF implantation as a potent neovascularization inducer, also proved the antiangiogenic capability of $\mathrm{ET}-18-\mathrm{OCH}_{3}$ [177], even though there was certain variability in the response. Rats received intraperitoneal injections of $20 \mathrm{mg} \mathrm{ET}-18-\mathrm{OCH}_{3} / \mathrm{kg}$, twice daily, and then found that 5 out of 9 animals receiving ET-18- $\mathrm{OCH}_{3}$ showed no corneal neovascularization, 3/9 showed intermediate inhibition, and only 1/9 failed to show any inhibition [177]. An antiangiogenic effect has also been reported for a phosphonate-derived ether lipid [19]. Unlike ET-18- $\mathrm{OCH}_{3}$, other related lipids have been reported to be proangiogenic, including the phospholipid PAF [179], 1-butyryl-glycerol [180] as well as the fatty-acid amide erucamide [181].

\subsection{Anti-invasive effects}

The metastatic spread of tumor cells from the primary tumor is the most prominent problem in treating cancer patients. A number of reports have shown the ability of ATLs to prevent invasion of tumor cells into surrounding tissues in vivo or into reconstituted basement 
membrane matrices in vitro [152,160,182-188]. However, no conclusive data have been obtained so far, and a molecular explanation for this action is still lacking. Furthermore, antithetic effects on invasion have also been reported, namely ET-18-OCH $\mathrm{CH}_{3}$ inhibits invasion of constitutively invasive cells [152,184,189,190], whereas it induces invasion of otherwise non-invasive cells [191,192]. Modification of glycoprotein processing, especially via changes in sialyltransferase, episialin-mediated neutralization of E-cadherin, membrane changes and induction of host tissue resistance have been suggested as possible explanations for the modulation of tumor cell invasiveness by ATLs [88,160,183,192-196], but clear-cut correlations remain difficult to establish. Furthermore, because of the pleiotropic activity of ATLs, it is still questionable whether modulation of invasiveness is a major action of ATLs or a rather secondary response dependent on cell type and experimental conditions.

\subsection{Effect on cell differentiation}

It has been reported that $\mathrm{ET}-18-\mathrm{OCH}_{3}$ is able to induce differentiation on human and mouse leukemic cell lines, including HL-60, U937, KG1 and M1 cells [197,198]. Other ATLs have also been reported to induce cell differentiation [199,200]. However, these studies were mostly based on morphological observations and analysis of a reduced number of biochemical assays. In contrast, some parameters that are normally associated with myeloid differentiation are not detected following ET-18- $\mathrm{OCH}_{3}$ treatment [201;Gajate, C. and Mollinedo, F., unpublished data], questioning the role of ET-18- $\mathrm{OCH}_{3}$ in inducing myeloid differentiation of leukemic cells.

\section{Effect of ET-18-OCH 3 on phospholipid metabolism and signal transduction}

The cytostatic and apoptotic effects of the ether lipid ET-18- $\mathrm{OCH}_{3}$ have been explained by its action on PC metabolism and on the apoptotic signaling, leading to the notion that the two major targets of ET-18-OCH 3 are CTP:phosphocholine cytidylyltransferase (CCT) and the cell death receptor Fas/CD95 (Fig. (9)), key proteins in the de novo synthesis of PC and in the initiation of an apoptotic response, respectively [202-205]. Also ET-18-OCH $\mathrm{OCH}_{3}$ seems to affect survival signaling and this can be of major importance in potentiating ET-18-OCH apoptosis.

\subsection{Modulation of phospholipid metabolism}


Phosphatidylcholine (PC) is essential for cell survival because it is a major structural building block of biological membranes and the precursor to other abundant membrane phospholipids: phosphatidylethanolamine [206] and sphingomyelin [207]. In addition PC is the precursor of second messengers following stimulation of cell surface receptors. In 1979, Modolell and co-workers [39] reported that ET-18-OCH $\mathrm{CH}_{3}$-treated Meth A sarcoma cells had reduced levels of PC. Subsequently, several groups have showed that ET-18-OCH $\mathrm{H}_{3}$ inhibits choline incorporation into PC [208-211]. CTP:phosphocholine cytidylyltransferase (CCT), which catalyzes the formation of CDP-choline, has long been recognized as the key enzyme controlling the PC biosynthetic pathway [202-204] and plays a determinant role in regulating de novo membrane phospholipid accumulation. CCT is necessary for cell survival [212-215], and absolutely requires the presence of specific lipids for activity [216,217]. CCT is activated by interactions with membranes containing diacylglycerols [218,219], fatty acids [220], or deficient in phosphatidylcholine [221,222], and is potently inhibited by sphingosine [223] and LPC [159]. CCT activity is also regulated by phosphorylation, with reduced CCT activity correlating with increased phosphorylation of the protein [224]. In addition, the soluble form of CCT is highly phosphorylated whereas the unphosphorylated CCT exhibits a greater degree of membrane association in cells [225-228]. cDNAs that encode for CCT, now named CCT $\alpha$, have been identified and sequenced in rat [229], hamster [230], mouse [231], and human [232], and there are only minor differences among these mammalian cDNAs. Recently, Lykidis and co-workers [233] have identified and sequenced a human cDNA that encoded a distinct CCT isoform, called CCT $\beta$, that is derived from a gene different from that encoding CCT $\alpha$. CCT $\alpha$ protein is thought to be an intranuclear protein [226-228,230,234], although other additional subcellular localizations have been reported, such as Golgi, endoplasmic reticulum and transport vesicles $[235,236]$, whereas CCT $\beta$ lacks the nuclear targeting sequence and the phosphorylation domain of CCT $\alpha$, suggesting that the new isoform differs from CCT $\alpha$ with regard to its subcellular localization and regulation [233].

The LPC non-metabolizable analog ET-18- $\mathrm{OCH}_{3}$ was found to inhibit choline incorporation into PC as well as total phospholipid synthesis as a result of CCT inhibition. The inhibition of PC synthesis seems to be an universal effect of ET-18-OCH $\mathrm{H}_{3}$ and other ATLs on cells [39,208-211,237-243], suggesting that this interference with PC metabolism may be responsible for the biological effects of ATLs. ET-18-OCH $\mathrm{OCH}_{3}$ and HPC mimic LPC, a physiological regulator of CCT activity, reducing the CDP-choline formation in intact cells and inhibit purified CCT in an in vitro assay by competing for the lipid activator site of the enzyme 
$[148,159,161]$. Supplementation of the medium with LPC provides an alternative pathway to PC formation, as LPC is taken up rapidly by cultured mammalian cells and acylated to form PC [244], thus circumventing the de novo PC biosynthetic pathway, and prevents apoptosis induced by either ET-18- $\mathrm{OCH}_{3}$ [148] or HPC [161]. The ability of LPC to prevent ether lipid-induced apoptosis supports the idea that maintenance of the bulk supply of membrane phospholipid is the determining factor in averting the drug-induced apoptosis program, rather than a specific role for CCT. However, it cannot be excluded the possibility that LPC inhibits uptake of the antineoplastic ether lipids. Interestingly, exogenous LPC supplementation was unable to restore the proliferation of ET-18-OCH -treated cells [148,161], indicating that ET-18-OCH 3 also has cytostatic properties that are not related to its interference with PC biosynthesis. This inability of LPC to override the cytostatic effect of $\mathrm{ET}-18-\mathrm{OCH}_{3}$ suggests that uptake of the ether lipid is not completely impaired in the presence of LPC. Likewise, addition of oleic acid, a potent CCT activator, restores PC synthesis to ET-18- $\mathrm{OCH}_{3}$-treated MCF-7 cells, but does not reverse the inhibition of cell growth [241]. In addition, overexpression of CCT in HeLa cells also prevented ET-18-OCH $\mathrm{H}_{3}$-induced apoptosis, as well as acylation of exogenous LPC, which circumvented the requirement for CCT activity [245]. However, neither CCT overexpression nor LPC supplementation allowed the HeLa cells to proliferate in the presence of ET-18-OCH , further supporting that the cytostatic action of ET-18- $\mathrm{OCH}_{3}$ was independent on its effect on membrane phospholipid synthesis activity [245]. This contrasts with studies carried out with HPC, where exogenous LPC prevents HPC-induced apoptosis and restores proliferation of HPC-treated cells [161]. These data indicate that ET-18- $\mathrm{OCH}_{3}$ and HPC, though sharing several actions, possess distinguishing structural features that make them to affect different targets and signaling pathways. Jackowski's group has proposed that CCT is a major target for ET-18-OCH $\mathrm{O}_{3}$ and HPC, acting as LPC analogs, and the subsequent interruption of PC synthesis at the CCT step is the primarily physiological imbalance that accounts for the cytotoxic action of these drugs. This action together with the inability of these drugs to be converted to PC or to be significantly metabolized by cells [95,127,135,218,246] could account for their cytotoxicity. However, these data raise the question whether the effect of ET-18- $\mathrm{OCH}_{3}$ on PC metabolism can explain the selective action of this drug on tumor cells. Also the fact that CCT overexpression bestows ET18- $\mathrm{OCH}_{3}$ resistance raises the question of whether or not the differences between sensitive and resistant cells can be attributed to differences in the level of CCT expression. Although this issue has not been addressed, it seems unlikely that differences in CCT expression accounts for the large range of drug sensitivity among cell types. 
In an attempt to explain the putative ET-18- $\mathrm{OCH}_{3}$ selectivity, Vogler and co-workers [247] reported a substitution in the sequence of CCT at nucleotide 751 from A in the sensitive HL-60 cell line to $\mathrm{G}$ in the resistant $\mathrm{K} 562$ cell line, that resulted in a change in amino acid number 251 from lysine in the HL-60 enzyme to glutamic acid in the K562 enzyme. These authors hypothesized that this mutation might result in a weaker affinity of ET-18- $\mathrm{OCH}_{3}$ to CCT in K562 cells, accounting for the resistance to the apoptotic action of the ether lipid. However, in a preliminary study with a wide number of cells, both resistant and sensitive to ET-18-OCH , we could not find experimental support to this notion as we did not detect the above reported mutation in a wide number of ET-18-OCH 3 -resistant and sensitive cells (Mollinedo, F. and Gajate, C., unpublished data).

Some evidences question a primary association of an alteration in the PC metabolism with the antitumor action of ET-18- $\mathrm{OCH}_{3}$. The induction of apoptosis by ET-18-OCH $\mathrm{OH}_{3}$ very rapid in certain leukemic cells, such as HL-60 cells, occurring after $3 \mathrm{~h}$ of treatment [164], whereas changes in PC metabolism require much longer incubation times. Also, several reports indicate a lack of correlation between interference with phospholipid metabolism and the sensitivity of different cell lines to the blockade of proliferation by ET-18- $\mathrm{OCH}_{3}$ [241,248,249]. In this regard, ET-18-OCH $\mathrm{O}_{3}$ was reported to inhibit PC content in both MCF-7 cells, which are sensitive to the growth inhibitory effects of ET-18- $\mathrm{OCH}_{3}$, and A549 cells which are relatively resilient to the compound [241]. Zhou and Arthur [241] found that changes in PC content were detected after inhibition of proliferation in MCF-7 cells induced by ET-18-OCH 3 , and although a decrease in the PC content was observed in ET-18- $\mathrm{OCH}_{3}$-treated A549 cells their proliferation was identical to that of untreated cells [241]. These authors also found a clear dissociation between the inhibition of PC synthesis and the inhibition of cell growth by ET-18- $\mathrm{OCH}_{3}$ in a number of epithelial tumor cells [241].

It has been also reported that ET-18- $\mathrm{OCH}_{3}$ inhibits acyl-CoA acyltransferase activity $\left(\mathrm{IC}_{50}, 80 \mu \mathrm{M}\right)$ [158]. As the concentration of ether lipid necessary to inhibit acyl-CoA acyltransferase is much higher than the drug dose required to exert its cytostatic and cytotoxic affects, the participation of this enzyme in the antitumor activity of the ether lipid can be ruled out. Although ET-18-OCH 3 treatment resulted in decreased incorporation of fatty acids into a number of phospholipids, notably phosphatidylcholine, however increased incorporation of fatty acids into other phospholipids, such as phosphatidylethanolamine has been detected, and again there was a lack of correlation between the incorporation of fatty acids into PC or other phospholipids and the action of ET-18-OCH 3 on cells [241,248,249]. ET-18-OCH 3 has also been 
reported to be a potent inhibitor of CoA-independent transacylase ( $\mathrm{IC}_{50}, 0.5 \mu \mathrm{M}$ ), using microsomes of human leukemic cells (HL-60 and U937 cell lines), and complete inhibition was observed at $3 \mu \mathrm{M}$ [250]. Additional inhibitors of this enzyme where found to induce apoptosis [250], suggesting that this inhibitory action could be involved in the cytotoxic action of the ether lipid. CoA-independent transacylase is an enzyme responsible for the movement of arachidonate between phospholipid molecular species. This enzyme transfers arachidonate from the sn-2 position of 1-acyl-containing phospholipids, such as 1-acyl-2-arachidonoyl-sn-glycero-3phosphocholine, to a suitable lyso-phospholipid acceptor, such as 1-alkyl-2-lyso- sn-glycero-3phosphocholine and 1-alkenyl-2-lyso-sn-glycero-3-phosphoethanolamine [251-253], and this is thought to be the mechanism by which inflammatory cells move arachidonate into specific phospholipid pools [254]. Many cancer cells contain high levels of 1-ether-linked phospholipids $[255,256]$, and it has been found a correlation between ET-18- $\mathrm{OCH}_{3}$ susceptibility and the ether lipid content of leukemia cells [257]. Winkler and co-workers [250] hypothesized that blocking CoA-independent transacylase would prevent arachidonate loading into 1-ether-linked phospholipid pools, and tentatively would influence cancer cell growth. However, the above inhibitory assays were not conducted in intact cells, but in microsomes, and again no correlation between changes in the movement of arachidonate into specific phospholipid pools and inhibition of proliferation in ET-18- $\mathrm{OCH}_{3}$-treated cells could be consistently observed [248]. In addition, $\mathrm{Lu}$ and Arthur [248] reported that although ET-18- $\mathrm{OCH}_{3}$ inhibited proliferation in human colon carcinoma T84 cells, the ether lipid led to an increase in the quantities of arachidonate and oleic acids incorporated into phospholipids, indicating that the net effect of the drug appears to be an activation of cellular acylation processes rather than their inhibition.

On these grounds, no clear conclusions about the relationship between the interference of ET-18- $\mathrm{OCH}_{3}$ on lipid metabolism and its antiproliferative and cytotoxic effects can be drawn when a large number of cells are examined. The ether lipid actions on lipid metabolism seem to depend largely on the cell type and experimental conditions used, and some compensatory mechanisms that overcome initial lipid metabolism perturbations seem to exist. Also, in some tumor cells, the reduced incorporation of fatty acid in cellular phospholipids seemed to be a consequence of the inhibition of proliferation by $\mathrm{ET}-18-\mathrm{OCH}_{3}$ rather than its cause. All these data make questionable that the interference in lipid metabolism is a primary and general cause for the inhibition of cell growth and cytotoxic action of ET-18- $\mathrm{OCH}_{3}$.

\subsection{Effects on apoptotic and survival signaling}


As described above ET-18- $\mathrm{OCH}_{3}$ behaves as a potent inducer of apoptosis and triggers rapidly an apoptotic pathway that involves: Fas/CD95, JNK signaling, mitochondria and caspase activation. However, in addition to be a potent inducer of apoptotic signaling, some reports suggest that ET-18- $\mathrm{OCH}_{3}$ can also inhibit survival signaling in tumor cells. This combination of apoptotic signaling enhancement and survival signaling inhibition makes ET-18-OCH a potential effective antitumor drug. Apoptosis induction is under tight control of both apoptosispromoting and apoptosis-inhibiting signals [258,259]. In this context, stimulation of the JNK cascade has been associated with apoptosis induction, whereas activation of MAPK is essential for cell growth and differentiation and may counteract apoptotic signaling. The balance between the proapoptotic JNK pathway and the antiapoptotic MAPK cascade may be critical in the cell's fate to die or to survive $[258,259]$. ET-18- $\mathrm{OCH}_{3}$ has been reported to be a potent activator of JNK [164,166], and to inhibit MAPK signaling [166,260].

Other signaling pathways related to survival have also reported to be affected by ET-18$\mathrm{OCH}_{3}$. Phosphatidylinositol-specific phospholipase C (PI-PLC) has been implicated as playing a role in cell proliferation. Powis and co-workers [261] have shown that ET-18-OCH 3 inhibits the in vitro activity of PI-PLC, whereas PC and PAF fail to inhibit this activity. ET-18-OCH resulted to be a more potent inhibitor of membrane-associated PI-PLC activity $\left(\mathrm{IC}_{50}<1 \mu \mathrm{M}\right.$, when incorporated into labeled-phosphatidylinositol(4,5)bisphosphate substrate micelles, and IC $_{50}$ of $5 \mu \mathrm{M}$ when added directly to the enzyme assay) than of cytosolic PI-PLC [261], suggesting a putative isoform specificity in this inhibition, as PI-PLC- $\gamma 1$ is mainly cytosolic and PI-PLC- $\beta 1$ is over $80 \%$ membrane bound [262]. However, ET-18-OCH 3 failed to inhibit phosphatidylcholine-specific PLC or PLD activity [261]. In a subsequent study, ET-18-OCH was reported to inhibit the association of $G \alpha_{q / 11}$ with PLC- $\beta 1$ [263]. Also, it was found that nonsmall cell lung carcinoma (NSCLC) cell lines were more sensitive than small cell lung carcinoma (SCLC) cells to the antiproliferative effects of ET-18- $\mathrm{OCH}_{3}$, and the PLC- $\beta 1$ protein levels were higher in SCLC cells compared with NSCLC cells [263], suggesting that increased PI-PLC- $\beta 1$ expression may contribute to the resistance of the SCLC cell lines to ET-18-OCH although the relevance of this finding in relation to the cytostatic action of ET-18-OCH 3 is not clear.

In addition, ET-18- $\mathrm{OCH}_{3}$ has been reported to reduce the number of epidermal growth factor receptor (EGFR) sites without affecting the affinity of the receptors in human breast cancer cell lines [264], and this reduction in the epidermal growth factor binding capacity might be related to the ET-18- $\mathrm{OCH}_{3}$-induced inhibition of the growth of hormone-dependent breast 
cancer cells. ET-18- $\mathrm{OCH}_{3}$ has also been shown to affect phosphatidylinositol-3-kinase (PI-3kinase), a signaling enzyme that interacts with receptor tyrosine kinases, and is involved via protein kinase B (PKB/Akt) in proliferative and survival responses [265]. The ether lipid ET-18$\mathrm{OCH}_{3}$ was found to inhibit immunoprecipitated or purified PI-3-kinase activity, from Swiss mouse 3T3 fibroblasts or bovine brain, with an $\mathrm{IC}_{50}$ of $35 \mu \mathrm{M}$ [266]. This inhibition was noncompetitive with ATP. Other ATLs, like HPC and SRI 62.834, also inhibited PI-3-kinase activity with an $\mathrm{IC}_{50}$ of 48 and $42 \mu \mathrm{M}$, respectively [266]. ET-18--OCH 3 was also found to inhibit PI-3kinase phosphorylation of endogenous phospholipid with an $\mathrm{IC}_{50}$ of $18 \mu \mathrm{M}$, when Swiss 3T3 cells were grown in the presence of ET-18- $\mathrm{OCH}_{3}$, and to inhibit platelet-derived growth factor (PDGF)-dependent PI-3-phosphates formation in v-sis NIH 3T3 intact cells with an IC $_{50}$ of 12.5 $\mu \mathrm{M}$ [266]. However, Swiss 3T3 and v-sis NIH 3T3 cells are rather resistant to growth inhibition by ET-18- $\mathrm{OCH}_{3}$ with $\mathrm{IC}_{50}$ of $19 \mu \mathrm{M}$ and $74.3 \mu \mathrm{M}$ (determined under continuous exposure to the ether lipid for 7 days) respectively [261], and NIH 3T3 cells are rather resistant to undergo ET18- $\mathrm{OCH}_{3}$-induced apoptosis [11]. Therefore, the inhibitory action on PI-3-kinase does not seem to play a major role in the cytostatic and proapoptotic actions of ET-18-OCH . However, it has been recently reported that a 1D-3,4-dideoxyphosphatidylinositol ether lipid is able to inhibit PI3-kinase and Akt activity as well as cell growth of NIH 3T3 cells [267].

On the other hand, ET-18- $\mathrm{OCH}_{3}$ increases the levels of reactive oxygen species $[165,167,268]$ and stimulates membrane lipid peroxidation [269] in tumor cells, but it is not clear the contribution of these effects to the cytotoxic action of the ether lipid.

\subsection{Effects on heat shock proteins}

Heat shock proteins (Hsps), are molecular chaperones that bind non-native states of other proteins and assist them to reach a functional conformation [270]. Hsps are induced in response to a wide range of stresses, including heat shock and exposure to chemical agents, protecting cells from the deleterious effects of stress and allowing them to recover and survive [271]. Hsps, particularly Hsp70 and Hsp27, protect cells from most of apoptotic stimuli and are commonly overexpressed in human tumors, correlating in certain cancers their expression with poor prognosis and resistance to therapy [272].

In cultured normal rat astrocytes, $\mathrm{ET}-18-\mathrm{OCH}_{3}$ has been found to promote a moderate induction of Hsp70, when used at low doses [273], suggesting that the ether lipid is able to induce a protective response in normal astrocytes. On the other hand, ET-18- $\mathrm{OCH}_{3}$ has also been reported to induce cell surface expression of Hsp70 without stimulating Hsp70 synthesis in the 
human chronic myelogenous leukemia cell line K562 [274], which is highly resistant to the ether lipid action [150,159,275]. This is of importance as cell surface-expressed Hsp70 may function as a recognition structure for natural killer (NK) cells [276-278], and thereby enhance cell death through the host immune surveillance. The amount of cell membrane-bound Hsp70 was synergistically increased following treatment of K562 cells with a sublethal heat $\left(41.8^{\circ} \mathrm{C}\right)$ and subsequent ET-18-OCH 3 incubation, resulting in a significantly enhanced sensitivity to lysis mediated by NK cells [279]. However, this up-regulation in Hsp70 cell surface and augmented sensitivity to NK cell-mediated lysis was not observed in normal peripheral blood lymphocytes and CD34+ progenitor cells [279]. On the other hand, it has been also reported that ET-18-OCH promotes a translocation of Hsp27 from the cytoplasm to the nucleus that correlates with induction of apoptosis in BG-1 human ovarian carcinoma cells [280]. However, the accumulation of Hsp27 around the nucleus seems to be an indicator of induced resistance or a protection mechanism [281, 282]. The significance and putative clinical implications of these findings must await further experimentation in both in vitro and in vivo models.

\subsection{Effects on protein kinase $C$}

Protein kinase C (PKC) activity includes a family of ubiquitously distributed Ser/Thr protein kinases that play a crucial role in several important physiological processes, including cell proliferation and differentiation. Many pharmacological inhibitors of PKC induce apoptosis, suggesting that PKC activity could render cells more resistant to apoptotic inducing agents [283]. PKC belongs to a large family of closely related proteins with multiple subspecies. PKC isozymes have been classified into three groups: the classical isoforms that are activated by $\mathrm{Ca}^{2+}$ and diacylglycerol or phorbol esters, the novel PKC (nPKC) that are $\mathrm{Ca}^{2+}$ independent but are activated by diacylglycerol and phorbol esters, and the atypical PKCs (aPKC) that are not activated by $\mathrm{Ca}^{2+}$, diacylglycerol or phorbol esters [284,285].

A number of conflicting and contradictory reports have been published concerning the effect of ET-18-OCH $\mathrm{OH}_{3}$ on PKC activity, and its relationship with ET-18-OCH $\mathrm{H}_{3}$-induced cytostatic and cytotoxic effects. These studies have to be interpreted cautiously, because so far most of the investigations on PKC activity by ether lipids have been performed under conditions suitable for testing calcium-dependent PKC activity, and therefore the putative action of ET-18-OCH $\mathrm{OCan}_{3}$ only be applied to these calcium-dependent PKC isoforms. ET-18-OCH $\mathrm{H}_{3}$ has been reported to inhibit PKC in cell free-systems with artificial membrane structures, composed of liposomes consisting of a mixture of phosphatidylserine and diacylglycerol, as cofactors [48,286,287]. This 
inhibition was described as competitive inhibition with respect to the phosphatidylserine binding site on the regulatory domain of the enzyme [287,288]. However, Heesbeen and co-workers [289] have demonstrated that ET-18- $\mathrm{OCH}_{3}$ can affect partially purified cytosolic PKC activity in different ways, depending on how the ether lipid is presented in the enzymatic assay. ET-18$\mathrm{OCH}_{3}$ inhibited PKC activity when added to a reaction mixture containing liposomes of phosphatidylserine and diacylglycerol; increased PKC activity when the ether lipid is present in mixed liposomes containing phosphatidylserine, diacylglycerol and increasing amounts of ET18- $\mathrm{OCH}_{3}$; and did not affect PKC activity when liposomes of ET-18-OCH $\mathrm{CH}_{3}$ were prepared and added separately to the liposomes of phosphatidylserine and diacylglycerol in the assay mixture. In this regard van Blitterswijk and co-workers [131] have also found no inhibition of PKC activity by the ether lipid when added as separate liposomes. To investigate the effect of ET-18$\mathrm{OCH}_{3}$ on PKC in intact cells, membranes of human leukemic cells were isolated before and after cell incubation with ET-18-OCH 3 and PKC activity determined. Under these more physiological conditions it was observed that the ether lipid induced a 3-fold increase in PKC activity, but this increase in PKC activity was not a consequence of translocation or de novo synthesis of PKC [289]. In contrast, using a similar approach, Berkovic and co-workers [290] found that ET-18$\mathrm{OCH}_{3}$ induced about 30\% reduction in PKC activity in intact cells without interfering with PKC translocation. The fact that PKC activity depends on the physical state of the lipid environment in different assay systems can explain these rather contradictory results. At any case, a putative role of PKC in ET-18-OCH $\mathrm{CH}_{3}$-induced cytostatic and cytotoxic effects in human leukemic cells is very unlikely, as a functional relationship between PKC level and effect of ET-18-OCH 3 on PKC activity in different sensitive and resistant cell types could not be found [291]. Also, ET-18$\mathrm{OCH}_{3}$ has been reported to inhibit in a similar way PKC activity in both ET-18-OCH 3 -resistant K562 and sensitive HL-60 cells [290], inhibition of PKC by ether lipids was not correlated with their antineoplastic activity on WEHI-3B and R6X-B15 cells [292], and cells depleted of PKC activity showed similar sensitivity or resistance to ET-18-OCH3 as cells expressing PKC activity [291]. Thus, inhibition of PKC by ET-18- $\mathrm{OCH}_{3}$ does not correlate with the antitumor effect of the ether lipid. However, under incubation conditions where ET-18-OCH 3 inhibited the proliferation of human breast adenocarcinoma MCF-7 cells, the ether lipid inhibited the phosphorylation of endogenous cellular proteins by PKC in intact cells [293]. Pretreatment of MCF-7 cells with ET-18-OCH 3 , at concentrations that inhibit cell proliferation in these cells, abolished the PKC-dependent phosphorylation of endogenous proteins, induced by phorbol-12myristate-13-acetate (PMA), in the same way as the specific PKC inhibitor Ro 31-8220, but the 
ether lipid did not affect translocation from cytosol to membrane of $\alpha, \gamma$ and $\varepsilon$ species of PKC [293]. ET-18- $\mathrm{OCH}_{3}$ has also been reported to inhibit PMA-induced protein phosphorylation in intact HL-60 cells [294] and in Madin Darby canine kidney (MDCK) cells [295]. Interestingly, ET-18- $\mathrm{OCH}_{3}$ itself stimulated the enhanced incorporation of ${ }^{32} \mathrm{P}$ into a number of proteins, revealed by two-dimensional gel electrophoresis as a series of spots with a molecular weight of about $31 \mathrm{kDa}$, in MCF-7 cells [293]. In contrast, no effect on basal phosphorylation was observed in similar studies with HL-60 or K562 leukemic cell lines [294]. The intriguing enhanced phosphorylation in MCF-7 cells could be due to inhibition of phosphatases or activation of kinases by ET-18- $\mathrm{OCH}_{3}$, and its relevance in ET-18- $\mathrm{OCH}_{3}$-mediated actions in MCF-7 cells, if any, remains to be elucidated. ET-18-OCH $\mathrm{CH}_{3}$ did not enhance protein kinase A activity [260]. In addition, some reports indicate that ET-18-OCH 3 antagonizes a number of additional biochemical effects of PKC stimulation by PMA, including transcription [295,296]. PMA and cell permeable diacylglycerol analogues $\left(\mathrm{DiC}_{8}\right)$ inhibit the induction of apoptosis by the anti-neoplastic agent cytosine arabinoside (ara-C; $1-\beta$-D-arabinofuranosylcytosine) [297], a DNA synthesis inhibitor that has been shown the most effective single agent against acute myelogenous leukemia [298], whereas down-regulation of PKC with bryostatin I results in enhanced apoptosis by ara-C in HL-60 cells [299]. In these cells, ara-C-induced apoptosis was stimulated by pretreatment with ET-18- $\mathrm{OCH}_{3}$ [300], which inhibits both ara-C and PMAinduced translocation of PKC $\beta I I$ [300].

Also, ET-18-OCH $\mathrm{OCH}_{3}$ inhibits PMA-stimulated PLD activity and DNA synthesis in NIH 3T3 fibroblasts [301], suggesting an inhibitory effect of ET-18-OCH $\mathrm{OH}_{3}$ on PK. Another piece of indirect evidence for the inhibitory effect of the ether lipid on PKC has been provided by the observation that ET-18- $\mathrm{OCH}_{3}$ inhibits PMA-induced activation of NF- $\mathrm{KB}$, but not that induced by TNF $\alpha$ or IL-1 $\alpha$ [302].

Quaternary ammonium analogues of ET-18- $\mathrm{OCH}_{3}$ have been reported to show PKC inhibitory activity in a cell-free system assay by acting as competitive inhibitors of activation by phosphatidylserine [303], and to inhibit the activation of PKC in intact cells and the growth of human leukemia cell lines [304]. In a more recent study, ET-18-OCH $\mathrm{CH}_{3}$ incorporated into liposomes, composed of dioleoylphosphatidylcholine:cholesterol: dioleoylphosphatidylethanolamine-glutaric:ET-18-OCH $(4: 3: 1: 2, \mathrm{v} / \mathrm{v})$, known as ELL-12 [305], had no significant effect on PKC activity or translocation induced by PMA in NIH 3T3 fibroblasts and in human leukemic Jurkat T cells [306]. Furthermore, ELL-12 did not inhibit

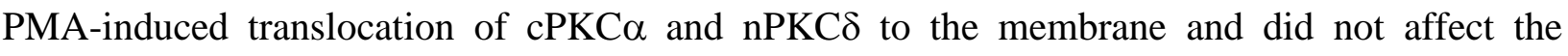




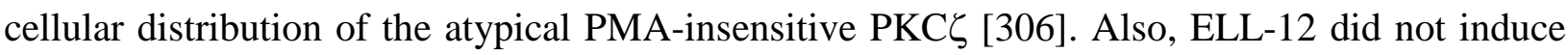
down-regulation of $\mathrm{cPKC} \alpha, \mathrm{nPKC} \delta$, or $\mathrm{PKC} \zeta$ [306].

These contradictory results indicate that experiments on inhibition or activation of PKC by ET-18- $\mathrm{OCH}_{3}$ have to be interpreted with caution since different results can be obtained depending on the cell examined as well as on the experimental procedure followed to assay PKC activity and the way of presentation of ET-18- $\mathrm{OCH}_{3}$. Also, the possibility of a non-specific detergent effect of ET-18-OCH${ }_{3}$ cannot be excluded, as many of the reported effects of ET-18$\mathrm{OCH}_{3}$ on PKC activity have been obtained when used at very high doses. At any case, the fact that similar effects on PKC activity have been reported on both ether lipid-resistant and sensitive cells, and the lack of a functional relationship, in many of the cases examined, between the actions promoted by ET-18- $\mathrm{OCH}_{3}$ on PKC activity with respect to its cytotoxic capacity, suggests that the antitumor effect of $\mathrm{ET}-18-\mathrm{OCH}_{3}$ must result from actions on other intracellular targets. Although a definitive answer on the effect of $\mathrm{ET}-18-\mathrm{OCH}_{3}$ on $\mathrm{PKC}$ remains to be established, especially taking into consideration all the distinct PKC isoforms, a possible role for PKC in ET-18-OCH $\mathrm{H}_{3}$-mediated cytotoxicity, however, seems highly questionable.

\section{Preclinical studies}

\subsection{Toxicity}

ATLs show little systemic toxicity in mice and rats regardless of the route of administration [1,4,187,307]. Mice injected daily for three weeks with ET-18- $\mathrm{OCH}_{3}$ at doses ranging from $1 \mu \mathrm{g} / \mathrm{mouse}(\approx 0.05 \mathrm{mg} / \mathrm{kg}$ of body weight) to $100 \mu \mathrm{g} / \mathrm{mouse}(\approx 5 \mathrm{mg} / \mathrm{kg}$ ) when ET-18-OCH $\mathrm{OCH}_{3}$ was dissolved in PBS, and up to $500 \mu \mathrm{g} / \mathrm{mouse}(\approx 25 \mathrm{mg} / \mathrm{kg})$ when ET-18-OCH was bound to serum proteins, did not show any pathologic values in blood and urine, irrespective of the application route, and pregnancies, births and the newborns showed no deviations from normal and developed without phenotypic abnormalities [1]. In both rats and mice single doses below $40 \mathrm{mg} / \mathrm{kg}$ of body weight are well tolerated. The oral $\mathrm{LD}_{50}$ dose for ET-18-OCH 3 in both mice and rats is $250 \mathrm{mg} / \mathrm{kg}$ of body weight, and the main toxic effect was gastrointestinal irritation $[1,2,4]$. Death in mice follows an extreme drop of body temperature. When ET-18$\mathrm{OCH}_{3}$ is given intravenously (i.v.), the major dose-limiting toxicity is hemolysis, likely due to the detergent nature of the agents. In acute toxicity studies, the $\mathrm{LD}_{50}$ values for single-dose i.v. administration of ET-18- $\mathrm{OCH}_{3}$ in mice, rats, and guinea pigs are reported to be between 40 and $55 \mathrm{mg} / \mathrm{kg}$ [2,308]. Irritation was observed at the sites of intravenous, intraperitoneal or intratumoral injection. $\mathrm{LD}_{50}$ can be higher when $\mathrm{ET}-18-\mathrm{OCH}_{3}$ is bound to serum proteins and 
herewith hemolysis can be reduced. There is a moderate increase in bilirubin and urea in blood.

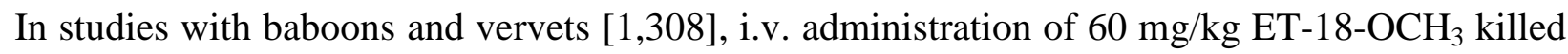
$50 \%$ of the animals and led to hemolysis in the surviving animals, increase in urea up to $200 \mathrm{mg}$ $\%$, and two baboons had enlarged kidneys on post mortem examination [308]. Other major organs like liver, stomach, thymus, spleen, appeared macroscopically normal. In subacute toxicity studies three vervets/group were injected three times/week with $1 \mathrm{mg} / \mathrm{kg}, 5 \mathrm{mg} / \mathrm{kg}$ and $20 \mathrm{mg} / \mathrm{kg}$ for 3 weeks. No side effects or pathologic values in blood and urine were found [1,308]. Higher doses led to diarrhea, vomiting and hemolysis with transient increase of bilirubin and urea in blood, and accompanied by an increase of hemoglobin, protein and glucose in urine $[1,308]$. The $\mathrm{LD}_{50}$ in rabbits was $5 \mathrm{mg} / \mathrm{kg}$ given i.v. in saline. The reason for this extraordinarily low $\mathrm{LD}_{50}$ is unknown, but this i.v. $\mathrm{LD}_{50}$ can further be raised up to $100 \mathrm{mg} / \mathrm{kg}$ when given slowly within 1-2 h, dissolved in serum or $5 \%$ albumin.

Significantly, the ET-18- $\mathrm{OCH}_{3}$ did not induce any myelotoxicity or bone marrow toxicity in vivo, which is so often characteristic of the conventional DNA-directed anticancer agents. In general, ET-18- $\mathrm{OCH}_{3}$ treatment does not result in significant systemic side effects and are tolerated well in animal models, and these findings have been confirmed in the later clinical trials. On the other hand, no mutagenic [309] or cytogenetic [310] effects were detected upon ET-18- $\mathrm{OCH}_{3}$ treatment.

In cultured rat hepatocytes incubated with different concentrations of ET-18-OCH 3 for 24 h, the $\mathrm{LC}_{50}$ (drug concentration causing $50 \%$ of cell death) was very high $170 \mu \mathrm{M}$, as measured by lactate dehydrogenase release [124], indicating that this drug does not show hepatotoxicity.

\subsection{Pharmacokinetics}

A major problem in pharmacokinetic studies is the lack of a reliable method for quantifying non-radiolabeled ET-18- $\mathrm{OCH}_{3}$ in plasma and other organs, because of the excess of endogenous phospholipids present in plasma and the difficulty of detecting AEPs in low concentrations. However, a number of chromatographic methods to determine lysophospholipids and analogues are being developed [311-317], and hopefully can be used in near future to allow more accurate AEP determinations in animal tissues.

Synthetic antitumor ether lipids, including ET-18- $\mathrm{OCH}_{3}$, considered in a broad sense as analogues of LPC, have a markedly higher metabolic stability in vivo than the natural compound. Pharmacokinetic data reveal gastrointestinal absorption of ET-18-OCH 3 after oral administration [311]. Furthermore, ATLs are slowly degraded in vivo, resulting in half-lives in the order of days 
$[139,318]$. This stability, together with the accumulation of $\mathrm{ET}-18-\mathrm{OCH}_{3}$ in the gastrointestinal tract, permits the absorption of the undegraded ET-18- $\mathrm{OCH}_{3}$ from the intestinal tract and, hence, oral application.

Using NMRI mice, Arnold and co-workers [139] found that, shortly after (60 min) intravenous injection of radiolabeled ET-18- $\mathrm{OCH}_{3}$, this ether lipid was distributed throughout the animal, and this distribution did not change between 1 and $10 \mathrm{~h}$ after injection. After $5 \mathrm{~h}$ of intravenous injection, the intestinal tract accumulated about $16-20 \%$ of the total activity recovered per organ, liver accumulated 12-14\%, kidneys accounted for about 5-7\%, blood for 2$6 \%$, lungs for $2-3 \%$, and the other organs examined (stomach, spleen, thymus, heart, and brain) accumulated about 1\% [139]. In most of the organs, a large amount of the accumulated activity remained undegraded (less than $40 \%$ degradation) after 4 days following ET-18-OCH $\mathrm{OCH}_{3}$ inection, and even in liver degradation resulted only in about 60\% [139]. ET-18- $\mathrm{OCH}_{3}$ dispersal in the body was similarly achieved irrespective of the administration route used, namely intravenous, intraperitoneally, oral and subcutaneous. However, these latter two dosing routes resulted in slower distribution throughout the entire animal and in significant depot effects in the gastrointestinal tract and skin, respectively [139]. Experiments with tumor-bearing mice indicated that ET-18-OCH $\mathrm{H}_{3}$ accumulated in the tumor, without undergoing degradation for long periods of time, with a relatively high tumor/healthy tissue ratio [139]. This might explain the relative enrichment of these compounds in the tumor in vivo. In this regard, a ${ }^{125} \mathrm{I}$-containing analogue of ET-18-OCH $\mathrm{OCH}_{3}$ was accumulated into tumor tissue with time and reached a tumor/blood ratio of 30:1 in a human colon carcinoma and 8:1 in a human melanoma xenograft in mice, proving to be useful for $\gamma$-scintigraphic tumor visualization [319]. Also, radioiodinated AEP and APC analogues have been shown to be selectively retained by a variety of rodent and human tumors [319-322], suggesting a potential role for these radiopharmaceutical ATL analogues as tumor imaging agents.

Surprisingly, a study of ET-18- $\mathrm{OCH}_{3}$ in rats, where the ether lipid was determined by high-performance thin-layer chromatography, reported that intact ET-18-OCH $\mathrm{CH}_{3}$ could not be detected in urine and feces, and did not accumulate significantly in tissues, suggesting a high level of biotransformation [138]. This is in total contrast with the pharmacokinetic data from mice. This discrepancy could be due to technical problems in detecting ET-18-OCH 3 levels or to great differences found in the metabolism of ET-18- $\mathrm{OCH}_{3}$ between animal species.

\subsection{Assays in animal models}


In parallel to studies in vitro, the antitumor effect of $\mathrm{ET}-18-\mathrm{OCH}_{3}$ has been studied in different tumor models in animals. ET-18- $\mathrm{OCH}_{3}$ retarded the growth of Ehrlich ascites tumor cells or Meth-A sarcoma cells in vivo [2]. ET-18-OCH $\mathrm{CH}_{3}$ showed moderate effects, after oral administration, on the subcutaneously (s.c.) transplantable mammary tumors TMA1 and TMA2 in BD-VI rats [323]. Oral administration of $10 \mathrm{mg} / \mathrm{kg} \mathrm{ET}-18-\mathrm{OCH}_{3}$ twice daily inhibited partially the growth of methylnitrosourea-induced mammary carcinomas in Sprague-Dawley rats [324]. This treatment was well tolerated without symptoms of toxicity. Oral administration of 6 $\mathrm{mg} / \mathrm{kg} \mathrm{ET}-18-\mathrm{OCH}_{3}$ did not exert any significant tumor-inhibiting effect, and administration of

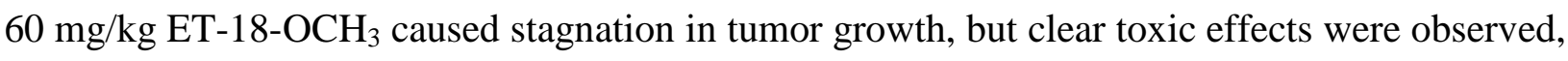
as manifested by a 13\% weight loss in 3 weeks and a 30\% mortality [324]. This could indicate a narrow therapeutic index of $\mathrm{ET}-18-\mathrm{OCH}_{3}$ in single-drug therapy, and therefore it can be suggested that the putative use of this compound in combination with other drugs might improve the therapeutic index of the ether lipid. ET-18- $\mathrm{OCH}_{3}$ administration significantly protected against leukemia development in 7,12-dimethylbenzanthracene-treated Long Evans rats [325]. However, the ether lipid had no effect in acetoxymethyl methylnitrosamine-induced rat colonic adenocarcinomas [326, 327]. In general, the responses obtained with different animal model studies have been moderate. However, the results were improved when ET-18-OCH 3 was given together with low doses of classical chemotherapeutic compounds, such as cis-platinum, cyclophosphamide and vinca-alkaloids [2].

In vivo antitumor activity of $\mathrm{ET}-18-\mathrm{OCH}_{3}$ against human solid tumors has also been shown using congenitally athymic mutant nude mice. Twenty two different human gynecologic malignant primary tumor cells (11 ovarian carcinoma, 8 endometrial carcinoma, 1 cervix carcinoma, 1 teratoblastoma, 1 ovarian tube carcinoma), that were shown to be killed in vitro following treatment with ET-18- $\mathrm{OCH}_{3}$, were transplanted subcutaneously in NMRI nude mice and ET-18- $\mathrm{OCH}_{3}$ was found to induce a significant retardation of the in vivo growing human tumors [327]. The ether lipid was administered daily either i.v. through the tail vein (500 $\mu \mathrm{g}$ ET18- $\mathrm{OCH}_{3}$ dissolved in NMRI mouse serum/mouse/day), or given orally (500 $\mu$ g ET-18-OCH dissolved in PBS/mouse/day), and no apparent side effects were recognized during the 3-week period of treatment [327]. The growth of MEXF 274 melanoma in NMRI nude mice was slightly retarded by intraperitoneal (i.p.) administration of 10 or $30 \mathrm{mg} / \mathrm{kg}$ body weight of ET-18-OCH , and the growth of the lung adenocarcinoma LXFA 526 was very weakly retarded after i.p. administration of $30 \mathrm{mg} / \mathrm{kg}$ body weight of $\mathrm{ET}-18-\mathrm{OCH}_{3}$ [328]. Intraperitoneal administration of ET-18- $\mathrm{OCH}_{3}$ did not increase the survival time of nude mice inoculated with L1210 murine 
leukemia cells [328]. On the other hand, ET-18- $\mathrm{OCH}_{3}$ (10 mg of ether lipid dissolved in 0.9\% sodium chloride/kg body weight, injected s.c. on the left rear flank three times per week for 2 weeks) reduced tumor growth of the MDA-MB 231 human breast carcinoma cell line injected s.c. in athymic nude Harlan Sprague Dawley mice consuming a fish oil diet [329]. Again there were no detectable harmful side effects on mice following ET-18-OCH $\mathrm{CH}_{3}$ treatment [329]. Human glioma xenografts in NMRI nude mice were reported to be sensitive to intratumorally applied ET-18- $\mathrm{OCH}_{3}$ [330].

In conclusion, a great variability has been found in the responses to ET-18- $\mathrm{OCH}_{3}$ with tumors treated identically with nude mice bearing human tumors. Taken together, the in vivo experiments carried out to examine the antitumor capacity of ET-18-OCH $\mathrm{CH}_{3}$ showed a rather poor antitumor effect of ET-18- $\mathrm{OCH}_{3}$ in single-drug therapy. In general, although some limited antitumor activity has been reported in vivo, no convincing potent antitumor effect has been observed in animal models. Also the different results reported with different tumors seem to suggest a rather tumor-specific action of ET-18-OCH 3 .

\section{Clinical studies}

ET-18-OCH $\mathrm{H}_{3}$ shows low toxicity and is a non-myelosuppressive agent. So far, purging in autologous bone marrow transplantation is the major indication for a putative clinical use of ET$18-\mathrm{OCH}_{3}$.

\subsection{Phase I studies}

In the period 1979-1982, sixteen patients suffering from advanced solid tumors or leukemias, with metastatic or widespread disease, and found in poor general health (Karnofsky performance score below 50 in most of the patients), the majority (fourteen) refractory to prior treatment, were treated in a phase I pilot study with ET-18-OCH 3 [331-333]. Eleven patients were treated intravenously, and five were given oral therapy. ET-18- $\mathrm{OCH}_{3}$ was aseptically dissolved in 20\% human albumin and infused i.v. Prolonged i.v. administration of 15-20 mg ET$18-\mathrm{OCH}_{3} / \mathrm{kg} /$ day at a concentration of $5 \mathrm{mg} / \mathrm{ml}$ ET-18- $\mathrm{OCH}_{3}$ containing 20\% human serum albumin could be continued safely. The maximum tolerated dose for the i.v. treated patients was either $50 \mathrm{mg} / \mathrm{kg}$ as a single injection, with limited toxicity in the gastrointestinal tract, with vomiting and diarrhea, or $20 \mathrm{mg} / \mathrm{kg}$ during daily dispensions, with reversible interstitial pulmonary edema and impairment of hepatic function as dose-limiting toxicity. Mitogen stimulation and mixed lymphocyte culture studies revealed possible immunosuppressive effects 
of high doses of ET-18- $\mathrm{OCH}_{3}$. Intravenous and oral treatment showed few encouraging response data since there were two partial remissions (defined as regression of all tumor parameters of more than 50\% with a remission duration for at least one month) in non-small cell lung (NSCL) cancers with remission durations of 5 and 6 months, and a reduction of peripheral leukemic blasts to less than $10 \%$ in an acute myelomonocytic leukemia [331-333]. There were no chromosomal changes in cytogenetic studies [310]. Frequent post-mortem examinations revealed no further toxicity.

Importantly, hematological or systemic side effects such as myelosuppression, nephro-, neuro- or hepatotoxicity were rarely observed in the clinical studies with ET-18- $\mathrm{OCH}_{3}$, even after prolonged therapy, and this feature distinguishes this antitumor agent from the anticancer agents currently available in the clinic.

\subsection{Phase II studies}

The evaluation of a phase II study with 116 NSCL patients treated with ET-18- $\mathrm{OCH}_{3}$ has been rather disappointing [334]. ET-18- $\mathrm{OCH}_{3}$ was initially applied in a daily oral dosage of 300 $\mathrm{mg}$ (dissolved in milk) over a period of 4 weeks, and then increased to a daily dosage of $900 \mathrm{mg}$ if tolerated well. Eighty one patients could be evaluated for remission status, but only 2 of them showed a partial remission, 68 showed no change, and 11 had unaltered progression of the tumor.

Interestingly, ET-18-OCH 3 has been reported to reduce circulating blasts in a patient with acute myelomonocytic leukemia refractory to treatment with daunomycin, cytosin arabinoside and thioguanine [332]. In May 1981 the patient entered a phase I study with ET-18-OCH in a $^{-}$ very poor general condition (Karnofsky index, 20; 84600 white blood cells/ $\mu$ with 93\% of leukemic cells) and received intravenously $\mathrm{ET}-18-\mathrm{OCH}_{3}$ dissolved in human albumin, at different doses ranging between 16-30 mg ET-18-OCH $/ \mathrm{kg} /$ day. After 11 days of daily treatment, the white blood count was 27800 leukocytes/ $\mu$ l with $64 \%$ of leukemic cells and recovery of normal hematopoiesis was first observed in the peripheral blood with an increase of neutrophils. Normal white blood count (6600 leukocytes/ $\mu$ l) was reached at day 15, but leukemic cells were still 51\%. Then, after one-month period without ether lipid treatment due to septic temperatures developed by the patient 3 days after hospital admission, white blood count again increased to 24400 leukocytes/ $\mu$ l with $84 \%$ of leukemic cells. When ET-18-OCH $\mathrm{OCH}_{3}$ aplication was resumed a second drop in the white blood count was observed though to a lesser extension, reaching a leukocyte count of 18000 with a leukemic population of 62\%. Despite normal 
hematopoiesis began to recover, the patient again developed septic temperatures dying on July $15^{\text {th }}, 1981$ [332].

\section{Purging}

Leukemic cells are particularly sensitive to the cytotoxic action of ET-18-OCH 3 , whereas normal bone marrow cells are relatively spared [11,37,335-338]. Normal bone marrow progenitor cells were not inhibited at drug doses that eliminated clonogenic leukemic cells in a mixture of normal and leukemic cells [339,340]. In a myelomonocytic mouse model, where a mixture of normal bone marrow and WEHI/3b leukemic cells were exposed to the ether lipid for $24 \mathrm{~h}$ before injection into lethally irradiated Balb/c littermates, there was a dose-related increase in survivors among the treated group, whereas the untreated animals succumbed to leukemia [341,342]. On these grounds ET-18- $\mathrm{OCH}_{3}$ was considered to be a good candidate for purging remission marrows before autologous bone marrow transplantation in leukemic patients, as it could be safely used for purging without prolonging marrow recovery due to its selectivity. In the autologous transplant setting, contamination of the graft by residual tumor cells is a risk for relapse after high-dose tumor therapy [343-346], and removal of tumor cells from bone marrow grafts by chemopurging with the selective antitumor agent ET-18-OCH $\mathrm{CH}_{3}$ seemed to be an effective and simple method. Purging in autologous bone marrow transplantation in leukemic patients has become so far the major indication for a putative clinical application of ET-18$\mathrm{OCH}_{3}$, and the groups of Wolfgang E. Berdel in Berlin (Germany) and William R. Vogler in Atlanta (USA) have carried out a lot of effort in this address. However, results, though encouraging, have not matched expectations. In these preclinical and clinical assays, the effect of cryopreservation was also analyzed since autologous marrow grafts are cryopreserved prior to reinfusion into the patient, and therefore the data including cryopreservation are obviously most relevant for potential clinical applications.

When the dose of ET-18- $\mathrm{OCH}_{3}$ was increased and the incubation time shortened to $4 \mathrm{~h}$ the majority of leukemic cells were killed with very little effect on normal marrow progenitor cells [347]. This selective cytotoxicity prompted the use of $\mathrm{ET}-18-\mathrm{OCH}_{3}$ in purging marrow from leukemic patients in remission in preparation for autologous bone marrow transplantation.

From April 1988 to February 1992 twenty nine patients with acute leukemia (19 acute myelogenous leukemia -AML- patients and 10 acute lymphoblastic leukemia -ALL- patients) entered into a clinical trial to assess the usefulness of ET-18- $\mathrm{OCH}_{3}$ in purging marrow from leukemic patients in preparation for autologous bone marrow transplantation [348-350]. 
Leukemic patients received marrow-ablative chemotherapy and total body irradiation followed by infusion of marrow purged for 4 hours at $37^{\circ} \mathrm{C}$ with $\mathrm{ET}-18-\mathrm{OCH}_{3}$. The cell concentration was adjusted to $2 \times 10^{7}$ cells/ml with RPMI 1640 medium and $10 \%$ autologous plasma and the initial purging dose of ET-18-OCH 3 was $50 \mu \mathrm{g} / \mathrm{ml}$. Then, the purging dose was increased to $75 \mu \mathrm{g} / \mathrm{ml}$, and this concentration became the recommended one for purging. One patient whose marrow was purged with $100 \mu \mathrm{g} / \mathrm{ml}$ failed to engraft. These studies led to the conclusion that cryopreservation in concert with purging with $75 \mu \mathrm{g} / \mathrm{ml}$ ET-18-OCH $\mathrm{H}_{3}$ represented a novel treatment in purging with encouraging results. In contrast to purging with cyclophosphamide derivatives in which normal bone marrow progenitor cells are markedly reduced [351-353], ET$18-\mathrm{OCH}_{3}$ had no effect on these cells when used either at 50 or $75 \mu \mathrm{g} / \mathrm{ml}$ doses before or after freezing. However, cryopreservation significantly reduced the number of normal bone marrow progenitor cells by about 35\%, but this reduction was not augmented by ET-18-OCH $\mathrm{O}_{3}$ exposure. Following transplantation, the median time to granulocyte recovery to $\geq 500 / \mu \mathrm{l}$ was 26 and 38 days for the 50 and $75 \mu \mathrm{g} / \mathrm{ml}$ ET-18-OCH 3 doses, respectively; and the median time to platelet recovery to $\geq 25000 / \mu \mathrm{l}$ was 43 and 49 days for the 50 and $75 \mu \mathrm{g} / \mathrm{ml}$ doses, respectively. These recovery times were in the absence of G-CSF. One patient that was given granulocyte-colony stimulating factor (G-CSF) had recovery of granulocytes to $\geq 500 / \mu \mathrm{l}$ by day 10 and to $\geq 1000 / \mu \mathrm{l}$ by day 12. The Kaplan-Meier plots of survival and disease-free survival of the 29 patients indicated that nine patients (31\%) remained in remission free of leukemia for a median of 630 days from 185 to 1613 days.

As hematologic recovery time after high-dose tumor therapy is greatly reduced by the use of peripheral blood derived progenitor cells (PBPC) when compared to bone marrow derived grafts [354,355], a study was accomplished to examine the effect of ET-18-OCH3 in the hematological recovery time from purged leukapheresis [356]. Buffy coats from peripheral blood of patients with breast cancer, non-Hodgkin's lymphoma multiple myeloma and primitive neuroectodermal tumor (PNET), were resuspended at $2 \times 10^{7}$ cells/ml in RPMI 1640 containing $10 \%$ autologous plasma and treated with $75 \mu \mathrm{g} / \mathrm{ml} \mathrm{ET}-18-\mathrm{OCH}_{3}$ for $4 \mathrm{~h}$ at $37^{\circ} \mathrm{C}$. Then, cells were frozen and stored in liquid nitrogen until use. The fraction of CFU-GM out of all CD34+ cells ranged between $1-10 \%(6.3 \pm 1.6 \%)$ in these leukapheresis. The recovery of total progenitor cells (total CFU including myeloid -cluster, CFU-GM-; erythroid -BFU-E, CFU-E-; and mixed -CFUGEMM-), quantified in semisolid cultures, was about $71 \%$ after purging, $63 \%$ after cryopreservation only, and about $47 \%$ after purging and cryopreservation; and the recovery of 
CFU-GM was 80\% after purging, 63\% after cryopreservation only, and 48\% after purging and cryopreservation. When comparable numbers of CFU-GM were used for transplantation after high-dose therapy, the clinical recovery times for leukocytes and platelets remained unchanged in comparison to patients receiving non-purged PBPC. White blood cell counts dropped to $<100$ white blood cells $/ \mu$ land to $<20000$ platelets/ $\mu$ l following high-dose therapy and recovery after autologous PBPC transplantation was supported by $10 \mu \mathrm{g} / \mathrm{kg} /$ day s.c. G-CSF in all patients. The median recovery times of non-purged vs. purged grafts to $>500$ white blood cell/ $\mu$ l were 9 vs. 8.5 days after transplantation, to $>2000$ granulocytes/ $\mu \mathrm{l} 10.5$ vs. 10 days, and to $>50000$ platelets/ $\mu \mathrm{l}$ 15.5 vs. 14 days, indicating a slight tendency towards shorter recovery times in patients receiving purged grafts. This suggests that ET-18- $\mathrm{OCH}_{3}$ purging of PBPC and cryopreservation leads to a significant, but tolerable loss of progenitor cells, with a rather short hematological recovery, indicating that the remaining progenitors after ether lipid treatment and cryopreservation are not qualitatively damaged and thereby this treatment does not compromise the advantage of rapid hematological recovery times with PBPC. However, the above reports placed particular emphasis on the effect of the ether lipid on normal progenitor cells and recovery times, but the action of the ether lipid on eliminating leukemic cells was not appropriately analyzed.

As mentioned above, a major limitation of autologous bone marrow transplantation is the putative contamination of the bone marrow to be reinfused following ablative chemotherapy with residual occult tumor cells that cause or contribute to relapses. The major goal in purging is to rid the stored marrow of any residual tumor cell and some approaches are being considered to increase the efficacy of the purging activity of ET-18- $\mathrm{OCH}_{3}$ while limiting toxic effects to normal hematopietic stem cells in order to shorten recovery times. These two variables, killing tumor cells while sparing normal ones, should be carefully examined using highly sensitive techniques in order to set up a promising purging protocol. Different approaches are being tested in vitro to optimize purging conditions. One approach to augment ether lipid purging activity is to use two (or more) synergistically interacting purging agents in combination. In this regard, Yamazaki and Sieber [357] have reported that ET-18-OCH $\mathrm{CH}_{3}$ synergistically enhances in vitro the antileukemic effect of merocyanine 540 (MC540)-mediated photodynamic therapy (PDT). A potent synergistic effect was found when different human and murine leukemic cell lines (1-5 $\mathrm{x}$ $10^{6}$ leukemic cells/ml) were treated with MC540-mediated PDT followed by ET-18-OCH

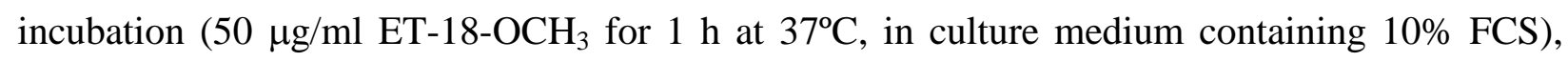
whereas the survival of normal human granulocyte-macrophage progenitors from volunteer donors was minimally reduced. Cryopreservation dramatically enhanced ( $\geq 3 \log )$ the 
antileukemic effect of purging with $\mathrm{MC5} 40+\mathrm{ET}-18-\mathrm{OCH}_{3}$, but only moderately reduced the surviving fraction of CFU-GM, giving a most favorable therapeutic index when cells were exposed sequentially to MC540-mediated PDT, ET-18-OCH $\mathrm{OCH}_{3}$, and cryopreservation [357].

The above mentioned reports used a very high dose of ET-18- $\mathrm{OCH}_{3}$, and this can be the reason for a partial toxic effect on normal progenitor cells. Another approach to optimize purging conditions in autologous bone marrow transplantation is to decrease ether lipid concentrations by lowering the amount of serum in the cultures. The cytotoxic effect of ET-18- $\mathrm{OCH}_{3}$ is affected by the proportion of serum in the culture medium [358,Gajate, C. and Mollinedo, F., unpublished data), decreasing the antitumor efficacy of the ether lipid with increasing concentrations of serum. Heesbeen and co-workers [98] have reported that the cytotoxic action and uptake of ET18- $\mathrm{OCH}_{3}$ was increased significantly at reduced serum levels, and that BSA was a major serum factor influencing ether lipid cytotoxicity. Assuming a BSA content of 23 g/l FCS, they found that equivalent BSA representing $2 \%$ FCS (that is $0.46 \mathrm{mg} \mathrm{BSA} / \mathrm{ml}$ ) allowed in vitro to decrease the amount of ether lipid to $20 \mu \mathrm{g} / \mathrm{ml}$ ( $4 \mathrm{~h}$ at $37^{\circ} \mathrm{C}$; 2 x $10^{6}$ cells) in order to eliminate practically the peripheral blood leukemic cells derived from five acute myeloid leukemia patients, with a $60 \%$ reduction in normal human bone marrow CFU-GM. Under these experimental conditions the use of $50 \mu \mathrm{g} / \mathrm{ml}$ ET-18- $\mathrm{OCH}_{3}$ led to complete destruction of normal marrow progenitors. These data suggest that free $\mathrm{ET}-18-\mathrm{OCH}_{3}$ molecules are more cytotoxic than the ether lipidalbumin complex. PAF is known to bind to albumin at four binding sites [359], and as the chemical structure of ET-18- $\mathrm{OCH}_{3}$ is closely related to PAF, it can be assumed that ET-18$\mathrm{OCH}_{3}$ shows a similar stoichiometry towards albumin. Moreover, plasma albumin has been found to bind fatty acids in a 4:1 ratio [360].

Another way to increase the efficacy of ET-18-OCH 3 is through its combination with heat. Hyperthermia has been reported to inhibit the proliferation of leukemic cells that are more sensitive to hyperthermic killing than their normal counterparts [361,362]. Okamoto and coworkers [340] combined hyperthermia and ether lipids and found that a 4-h incubation of leukemic cells with $50 \mu \mathrm{g} / \mathrm{ml}$ of $\mathrm{ET}-18-\mathrm{OCH}_{3}$ with heat $\left(42^{\circ} \mathrm{C}\right)$ added during the last hour resulted in a further reduction of leukemic cell lines or leukemic progenitors obtained from acute myeloid leukemia (AML) patients, while spared 50\% of normal hematopoietic progenitors after cryopreservation.

On the other hand high-dose chemotherapy with autologous bone marrow transplantation is a promising approach to the treatment of advanced metastatic and hormone-unresponsive breast cancer [363]. Dietzfelbinger and co-workers [364] treated a mixture of normal human 
bone marrow cells with malignant HTB 19 breast cancer cells at a ratio of 100:1, to simulate an autologous bone marrow transplantation situation, with $75 \mu \mathrm{g} / \mathrm{ml} \mathrm{ET}-18-\mathrm{OCH}_{3}$ for $4 \mathrm{~h}$ at $37^{\circ} \mathrm{C}$ and subsequent cryopreservation, and found a considerable reduction of HBT 19 colonies (by up to $1 \log$ growth reduction), whereas the normal human hematopoietic progenitors showed a recovery of more than $50 \%$. Although the purging effect of ET-18-OCH $\mathrm{H}_{3}$ was less pronounced in breast cancer cells than in leukemic and lymphoma cells, this effect suggests that ET-18-OCH could be useful for purging bone marrow for autologous bone marrow transplantation not only in acute leukemia, but also in other cancers, like breast cancer.

\section{Liposomes and ET-18-OCH}

Despite ET-18-OCH $\mathrm{OH}_{3}$ shows itself as a very effective and promising antitumor agent, optimal clinical therapeutic exploitation of $\mathrm{ET}-18-\mathrm{OCH}_{3}$ has been hampered in part by some side effects, including gastrointestinal (abdominal pain, nausea, vomiting, and diarrhea), lung, liver, renal, and hemolytic toxicities [3,4,333,365]. Especially hemolysis has been considered a major side effect of ET-18-OCH 3 when applied i.v. To alleviate these adverse effects and to improve antitumor activity, a number of analogues of ET-18- $\mathrm{OCH}_{3}$ have been synthesized, but none has been shown to be clinically superior to $\mathrm{ET}-18-\mathrm{OCH}_{3}$ thus far. In agreement with the notion that incorporation of anticancer drugs into liposomes usually improve therapeutic efficiency while markedly reduce nonspecific toxicity in vivo [366-370], a stable liposome-based formulation of ET-18-OCH named

ELL-12

(dioleoylphosphatidylcholine/cholesterol/dioleoylphosphatidylethanolamine-glutaric acid/ET-18$\left.\mathrm{OCH}_{3}\right)$ (4:3:1:2, molar ratio) has been shown to be acutely less hemolytic both in vitro and in vivo [149, 305, 371]. Association of $\mathrm{ET}-18-\mathrm{OCH}_{3}$ with stable liposomes greatly reduced hemolytic effects -up to 20 or more times- of the free ether lipid [149,305,371,372,Mollinedo, F., del Canto-Jañez, E. and Gajate, C., unpublished data], suggesting that liposome association reduced drastically the detergent-like effect of free $\mathrm{ET}-18-\mathrm{OCH}_{3}$, protecting cells against acute membrane lytic effects, while preserved the growth inhibitory [149] and apoptotic [373, Mollinedo, F., del Canto-Jañez, E. and Gajate, C., unpublished data] properties of the ether lipid. These data clearly indicate that the lytic effects are not responsible for the more specific growthinhibitory and apoptotic effects of ET-18- $\mathrm{OCH}_{3}$.

In addition, the liposome formulation of ET-18-OCH $\mathrm{ELL}_{3} 12$ was about 4-8 fold less acutely toxic than free ET-18- $\mathrm{OCH}_{3}$ after i.v. administration and showed a higher antitumor activity in vivo than $\mathrm{ET}-18-\mathrm{OCH}_{3}$ in three tumor models, namely i.p. P388 leukemia, Lewis lung 
cancer lung metastases and B16/F10 melanoma in mice, resulting in a therapeutic index at least 4-fold higher than ET-18-OCH 3 [371].

As mentioned above, an important in vivo toxicity of ET-18-OCH $\mathrm{CH}_{3}$ is hemolysis. Free ET18- $\mathrm{OCH}_{3}$ caused severe acute hemolysis in mice (approximately $5 \%$ of circulating red blood cells hemolysed in $30 \mathrm{~min}$ ) at a single i.v. dose of $50 \mathrm{mg} / \mathrm{kg}$ [371] and caused detectable hemolysis at $12.5 \mathrm{mg} / \mathrm{kg}$. In a comparative study of acute toxicity in C57 female mice, the maximum tolerated dose for i.v. administration of free $\mathrm{ET}-18-\mathrm{OCH}_{3}$ was found to be $25-50$ $\mathrm{mg} / \mathrm{kg}$, whereas the maximum tolerated dose for ELL-12 was approximately $75-200 \mathrm{mg} / \mathrm{kg}$ [371]. Although the in vitro hemolytic effects of $\mathrm{ET}-18-\mathrm{OCH}_{3}$ can be significantly reduced by mixing ET-18- $\mathrm{OCH}_{3}$ with albumin [374], in vivo toxicity was not significantly attenuated because the $\mathrm{LD}_{50}$ of a single i.v. dose of $\mathrm{ET}-18-\mathrm{OCH}_{3}$ bound to albumin is about $50 \mathrm{mg} / \mathrm{kg}$ in mice [3]. It is interesting to note that the acute toxicity of free ET-18-OCH $\mathrm{H}_{3}$ and ELL-12 seemed to be reduced in tumor-bearing animals [371]. Also, ELL-12 showed much lower detectable toxicity than $\mathrm{ET}-18-\mathrm{OCH}_{3}$ by the s.c. route.

Association with liposomes reduces the in vivo toxicities of several drugs, and most liposome formulations used in clinical trials have been developed to reduce parent drug toxicities while maintaining therapeutic efficacy [367,368,375]. However, the propensity of liposomal drug carriers to be taken up by the phagocytic cells of the reticuloendothelial system can affect many important properties, especially the in vivo circulation lifetime. Some factors that influence the rate of liposome clearance by phagocytic cells include serum C3 complement factor that opsonizes particles and liposomes [376,377], liposomal size, surface charge, surface hydrophilicity, specific lipid composition, and aggregation [378]. Because liposome-associated ET-18-OCH $\mathrm{OHL}_{3}$ EL12 is able to reduce side-effects, preserving antitumor activity, developing of new liposome-associated ET-18-OCH 3 formulations with reduced uptake by the phagocytic cells leading to enhanced circulation lifetimes can be an important goal to achieve a better therapeutic efficacy of ET-18-OCH 3 when administered i.v.

\section{Additional therapeutic indications of ET-18-OCH}

ET-18- $\mathrm{OCH}_{3}$ and other ATLs have also attracted scientific and clinical interest in the treatment of diseases other than cancer and some in vitro and in vivo studies support their biomedical role in these new therapeutic indications.

It has been reported that $\mathrm{ET}-18-\mathrm{OCH}_{3}$ prevents induction of chronic relapsing experimental allergic encephalomyelitis (EAE) in rats and mice [379-382]. EAE is an 
experimental autoimmune disease of the central nervous system white matter, characterized by a T-cell response to myelin basic protein, sharing clinical and pathological features with human multiple sclerosis, and is therefore regarded as a good experimental model for human demyelinating disease [383-385]. In a pilot study with a limited number of multiple sclerosis patients, at different stages of the disease, ET-18-OCH $\mathrm{OCH}_{3}$ treatment (150-300 mg twice/week) improved their clinical symptoms [2]. Although EAE in animals and multiple sclerosis in humans cannot be fully compared, it has been assumed that in both diseases autoaggressive Tlymphoblats play a key role [386]. ET-18- $\mathrm{OCH}_{3}$ has been reported to kill selectively mitogenactivated peripheral blood lymphocytes by apoptosis in vitro, whereas resting lymphocytes are not affected [85,387]. These data suggest a putative beneficial role of ET-18- $\mathrm{OCH}_{3}$ in certain autoimmune diseases, including those involving the central nervous system. In this regard, it is worthwhile to note that ET-18- $\mathrm{OCH}_{3}$ is able to cross the blood brain barrier [139].

ET-18- $\mathrm{OCH}_{3}$ and a number of analogues have been reported to inhibit human immunodeficiency virus (HIV) reverse transcriptase and the production of infectious virus particles [388,389], suggesting a potential role as anti-HIV agents.

A major biomedical activity of ATLs, in particular HPC (miltefosine) and ET-18-OCH (edelfosine), seems to be as antiparasitic agents. ATLs have been reported to show in vitro and in vivo cytotoxic activity against a number of parasites, including Leishmania (L. donovani, L. major, L. mexicana, L. panamensis, L. infantum), Trypanosoma cruzi, Trypanosoma brucei and Entamoeba histolytica [390-399]. These data together with the disponibility of ATLs as oral drugs raise the possibility that ATLs may have a role as an oral treatment of several parasitic diseases and in the growing problem of AIDS-associated visceral leishmaniasis (kala-azar) in CD4 cell depleted patients [400]. In this regard, it has recently shown that HPC behaves an effective oral medication for Indian visceral leishmaniasis [401]. In a multicenter, phase II trial in which four 30-person cohorts with Indian visceral leishmaniasis received 50, 100 or $150 \mathrm{mg}$ of HPC per day for four or six weeks, 95\% of the patients were cured, defined by the absence of parasites in a splenic aspirate obtained two weeks after completion of treatment [401]. The mechanisms underlining the antiparasitic role of ATLs remain to be unraveled. Leishmania is known to contain high levels of ether phospholipids [402-406], and it has been suggested that a perturbation of the ether lipid remodeling could be responsible for the anti-leishmanial action of these drugs [407]. 


\section{Concluding remarks}

ET-18-OCH $\mathrm{OCH}_{3}$, a synthetic analogue of LPC that is considered the prototype of AEPs and even of ATLs, is an interesting new class of antineoplastic agent that possesses high metabolic stability, localizes in cellular membranes, and has no known direct interaction with DNA. ATLs, including ET-18- $\mathrm{OCH}_{3}$, are distinguished by their very low rates of metabolism in vitro and in vivo, are active per se and not prodrugs, and they share common properties that are derived from their structural characteristics. ET-18- $\mathrm{OCH}_{3}$ modulates cell signalling pathways at a number of key stages in the signal transduction cascade, including receptor function, second messenger generation, and protein phosphorylation. $\mathrm{ET}-18-\mathrm{OCH}_{3}$ shows some unique features that make this compound an extremely interesting antitumor drug, not only for its putative clinical use in cancer treatment but for its mode of action that can represent a new framework in designing novel antitumor drugs. The ET-18- $\mathrm{OCH}_{3}$ biological effects depend largely on the chemical structure of the molecule [11] and thereby, the high metabolic stability of the drug favors its biological action. Two major biochemical effects account for its antitumor activity, namely the inhibition of PC biosynthesis and the induction of apoptosis in tumor cells. ET-18-OCH $\mathrm{O}_{3}$ inhibits certain enzymes of the phospholipid metabolism, especially CCT, involved in PC biosynthesis. As the normal phospholipids of cellular membranes are continuously turned over to renew the phospholipid moieties, the presence of non-metabolizable ET-18- $\mathrm{OCH}_{3}$ leads to an interference with this vital dynamic cellular process. Also, as ET-18-OCH 3 is very slowly, if at all, degraded by tumor cells, its insertion and accumulation in the plasma membrane leads to a disarrangement of the phospholipid bilayer and to a drastic change in the biochemical and biophysical features of the plasma membrane. Also, as ET-18-OCH 3 inhibits acyltransferase in the cell, while PLA 2 is not inhibited, the continued deacylation of phospholipids can result in the accumulation of LPC that can contribute to the cytotoxic action of the drug. A critical process in the cytotoxic action of ET-18- $\mathrm{OCH}_{3}$ is due to its selective apoptotic effect for malignant cells, sparing normal cells. This apoptotic affect is causally related to the selective cellular uptake of the antitumor ether lipid drug into the cancer cell, and to the subsequent intracellular triggering of Fas/CD95, independently of FasL, by the ether lipid after the latter is inside the cell. Thus, ET-18-OCH $\mathrm{OH}_{3}$ the first antitumor drug acting through the intracellular activation of the cell death receptor Fas/CD95. This novel mechanism of action for an antitumor drug represents a new way to target tumor cells in cancer chemotherapy and can be of interest as a new framework in designing novel antitumor drugs. Understanding how ET-18-OCH 3 enters the tumor cell and triggers Fas/CD95 activation from inside the cell will constitute major subjects of research in the 
following years. Unraveling these processes will open a new way to target tumor cells in cancer chemotherapy. The fact that ET-18- $\mathrm{OCH}_{3}$ acts through its effects on apoptotic signaling indicates that it can be active against a wide array of tumor cells independent of their proliferative capacity. This is important as many tumors have a low proliferation rate, but instead show a deficient apoptotic response, and thereby a high apoptotic threshold. In vivo, the anticancer effects of ET-18- $\mathrm{OCH}_{3}$ probably result from a combination of direct effects on the target cancer cells, as a major drug effect, and up-regulation of host anti-cancer defense systems, as a minor drug action. Interestingly, ET-18- $\mathrm{OCH}_{3}$ shows some pharmacological features of major importance in cancer treatment: a) selective induction of apoptosis in cancer cells, sparing normal cells; b) no interaction with DNA; c) lack of mutagenicity; d) it passes through the blood brain barrier; e) it is fully active over oral route.

Will ET-18- $\mathrm{OCH}_{3}$ be useful in the treatment of cancer? Time will tell, since clinical trials have started for patients with distinct tumors. HPC, a prototype for APCs, has been recently marketed for the topical treatment of subcutaneous breast cancer metastases. So far, most of the clinical studies with ET-18- $\mathrm{OCH}_{3}$ have been incomplete or rather anecdotic, and there is a notorious lack of multicentric clinical trials. The fact that only some tumors respond to ET-18$\mathrm{OCH}_{3}$ is an indication that its overall effect is more specific than that of the classical cytostatic agents. Thus, before launching an exhaustive clinical study, further preclinical studies should be carried out in order to determine the most suitable type of cancer to be treated with ET-18-OCH , to fix the optimal dose, route and way of administration, and to examine putative synergistic combinations with other additional drugs or therapies to increase the antitumor potential. Also, changes in the chemical structure of the ET-18- $\mathrm{OCH}_{3}$ leading to an increase in the antitumor activity of the drug, preserving its selectivity cytotoxicity against tumors and its metabolic stability, will be needed in order to enhance the efficiency of the drug. On the other hand, the selectivity of ET-18- $\mathrm{OCH}_{3}$ for cancer cells as well as its accumulation in tumors turns this drug into an extremely attractive compound to identify tumor localization and metastasis.

ATLs, including ET-18- $\mathrm{OCH}_{3}$, show pleiotropic actions leading to multiple putative biomedical applications. Due to this pleiotropy, other therapeutic applications for these versatile agents may yet await discovery. Thus, ATLs are powerful drugs in the therapy of parasitic diseases, and are considered to be the most promising antileishmanial agents. Also, ET-18-OCH seems to be an interesting drug in certain autoimmune diseases, including multiple sclerosis. Altogether the above data warrant further investigation to fully unravel the mechanisms of action 
of ET-18- $\mathrm{OCH}_{3}$ in the distinct biomedical indications, and to enhance the antineoplastic effect and other therapeutic actions of the ether lipid.

\section{Acknowledgements}

The work of the authors was supported by grant CDTI 97-0355 from INKEYSA and Ministerio de Industria y Energía of Spain, and grants 1FD97-2018-C02-01 and 1FD97-0622 from the European Commission and Comisión Interministerial de Ciencia y Tecnología of Spain.

\section{References}

1. Berdel, W.E.; Bausert, W.R.E.; Fink, U.; Rastetter, J. and Munder, P.G. (1981) Anticancer Res., 1, 345-351.

2. Munder, P.G. and Westphal, O. (1990) Chem. Immunol., 49, 206-235.

3. Lohmeyer M. and Bittman R. (1994) Drugs of the Future, 19, 1021-1037.

4. Houlihan, W.J.; Lohmeyer, M.; Workman, P. and Cheon, S.H. (1995) Med. Res. Rev., 15, 157-223.

5. Brachwitz, H. and Vollgraf, C. (1995) Pharmac. Ther., 66, 39-82.

6. Maly, K.; Überall, F.; Schubert, C.; Kindler, E.; Stekar, J.; Brachwitz, H. and Grunicke, H.H. (1995) Anti-cancer Drug Design, 10, 411-425.

7. Arthur, G. and Bittman, R. (1998) Biochim. Biophys. Acta, 1390, 85-102.

8. Wieder, T.; Reutter, W.; Orfanos, C.E. and Geilen, C.C. (1999) Prog. Lipid Res., 38, 249259.

9. Mollinedo, F.; Martínez-Dalmau, R. and Modolell, M. (1993) Biochem. Biophys. Res. Commun., 192, 603-609.

10. Diomede, L.; Colotta, F.; Piovani, B.; Re, F.; Modest, E.J. and Salmona, M. (1993) Int. J. Cancer, 53, 124-130.

11. Mollinedo, F.; Fernández-Luna, J.L.; Gajate, C.; Martín-Martín, B.; Benito, A.; MartínezDalmau, R. and Modolell, M. (1997) Cancer Res., 57, 1320-1328.

12. Gajate, C.; Fonteriz, R.I.; Cabaner, C.; Alvarez-Noves, G.; Alvarez-Rodriguez, Y.; Modolell, M. and Mollinedo, F. (2000) Int. J. Cancer, 85, 674-682.

13. Mickeleit, M.; Wieder, T.; Buchner, K.; Geilen, C.; Mulzer, J. and Reutter, W. (1995) Angew Chem. Int. Ed. Engl., 107, 2879-2881.

14. Marino-Albernas, J.; Bittman, R.; Peters, A. and Mayhew, E. (1996) J. Med. Chem., 39, 3241-3247. 
15. Mickeleit, M.; Wieder, T.; Arnold, M.; Geilen, C.C.; Mulzer, J. and Reutter, W. (1998) Angew Chem. Int. Ed. Engl., 110, 371-373.

16. Samadder, P.; Byun, H.-S.; Bittman, R. and Arthur, G. (1998) Anticancer Res., 18, 465-470.

17. Wiese, A.; Wieder, T.; Mickeleit, M.; Reinöhl, S.; Geilen, C.C.; Seydel, U. and Reutter, W. (2000) Biol. Chem., 381, 135-144.

18. Qiao, L.; Nan, F.; Kunkel, M.; Gallegos, A.; Powis, G. and Kozikowski, A.P. (1998) J. Med. Chem., 41, 3303-3306.

19. Jackson, J.K.; Burt, H.M.; Oktaba, A.M.; Hunter, W.; Scheid, M.P.; Mouhajir, F.; Lauener, R.W.; Shen, Y.; Salari, H. and Duronio, V. (1998) Cancer Chemother. Pharmacol., 41, 326-332.

20. Shin, J.; Qualls, M.M.; Boomer, J.A.; Robarge, J. and Thompson, D.H. (2001) J. Am. Chem. Soc., 123, 508-509.

21. Bittman, R.; Qin, D.; Wong, D.-A.; Tigyi, G.; Samadder, P. and Arthur, G. (2001) Tetrahedron, 57, 4277-4282.

22. Jendrossek, V.; Erdlenbruch, B.; Hunold, A.; Kugler, W.; Eibl, H. and Lakomek, M. (1999) Int. J. Oncol., 14, 15-22.

23. Erdlenbruch, B.; Jendrossek, V.; Gerriets, A.; Vetterlein, F.; Eibl, H. and Lakomek, M. (1999) Cancer Chemother. Pharmacol., 44, 484-490.

24. Hilgard, P.; Klenner, T.; Stekar, J.; Nössner, G.; Kutscher, B. and Engel, J. (1997) Eur. J. Cancer, 33, 442-446.

25. Knebel, N.G.; Grieb, S.; Winkler, M.; Locher, M.; van der Vlis, E. and Herheij, E.R. (1999) J. Chromatogr., 721, 257-269.

26. Wieder, T.; Perlitz, C.; Wieprecht, M.; Huang, R.T.C.; Geilen, C.C. and Orfanos, C.E. (1995) Biochem. J., 311, 873-879.

27. Brachwitz, H.; Bergmann, J.; Fichtner, I.; Thomas, Y.; Vollgraf, C.; Langen, P. and Berdel, W.E. (1998) J. Lipid. Res., 39, 162-172.

28. Chresta, C.M.; Arriola, E.L. and Hickman, J.A. (1996) Behring Inst. Mitt., 97, 232-240.

29. Munder, P.G.; Ferber, E.; Modolell, M. and Fischer, H. (1969) Int. Arch. Allergy Appl. Immunol., 36, 117-128.

30. Munder, P.G. and Modolell, M. (1973) Int. Arch. Allergy Appl. Immunol, 45, 133-135.

31. Weltzien, H.U. (1979) Biochim. Biophys. Acta, 559, 259-287.

32. Mulder, E. and van Deenen, L.L.M. (1965) Biochim. Biophys. Acta, 106, 348-356.

33. Soodsma J.F.; Piantadosi, D. and Snyder, F. (1970) Cancer Res., 30, 309-311. 
34. Munder, P.G.; Modolell, M.; Andreesen, R.; Weltzien, H.U. and Westphal, O. (1979) Immunopathology, 2, 187-203.

35. Munder, P.G. (1982) Human Cancer Immunol., 3, 17-29.

36. Tarnowski, G.S.; Mountain, I.M.; Stock, C.C.; Munder, P.G.; Weltzien, H.U. and Westphal, O. (1978) Cancer Res., 38, 339-344.

37. Andreesen, R.; Modolell, M.; Weltzien, H.U.; Eibl, H.; Common, H.; Löhr, G.W. and Munder, P.G. (1978) Cancer Res., 38, 3894-3899.

38. Andreesen, R.; Modolell, M. and Munder, P.G. (1979) Blood, 54, 519-523.

39. Modolell, M.; Andreesen, R.; Pahlke, W.; Brugger, U. and Munder, P.G. (1979) Cancer Res., 39, 4681-4686.

40. Kny, G. (1969) Über Lysolecithin-Analoga - Synthese und biologische Eigenschaften. Chemical Diploma Thesis, Univ. Freiburg, Germany.

41. Chignard, M.; Le Couedic, J.P.; Tence, M.; Vorgaftig, B.B. and Benveniste, J. (1979) Nature, 279, 799-800.

42. Prescott, S.M.; Zimmerman, G.A. and McIntyre, T.M. (1990) J. Biol. Chem., 265, 1738117384.

43. Snyder, F. (1995) Biochem. J., 305, 689-705.

44. Demopoulos, C.A.; Pinckard, R.N. and Hanahan, D.J. (1979) J. Biol. Chem., 254, 93559358.

45. Hanahan, D.J.; Demopoulos, C.A.; Liehr, J. and Pinckard, R.N. (1980) J. Biol. Chem., 255, 5514-5516.

46. Taguchi, H. and Armarego, W.L.F. (1998) Med. Res. Rev., 18, 43-89.

47. Paltauf, F. (1994) Chem. Phys. Lipids, 74, 101-139.

48. Daniel, L.W.; Small, G.W.; Schmitt, J.D.; Marasco, C.J.; Ishaq, K. and Piantadosi, C. (1988) Biochem. Biophys. Res. Commun., 151, 291-297.

49. Bergmann, W. and Stansbury, H.A.Jr. (1943) J. Org. Chem., 8, 283.

50. Urata, K. and Takaishi, N. (1996) JAOCS, 73, 819-830.

51. Boeryd, B. (1958) Nature, 182, 1484-1485.

52. Osmond, D.G.; Roylance, P.J. and Webb, A.J. (1963) Acta Haematol., 29, 180-186.

53. Boeryd, B.; Hallgren, B. and Ställberg, G. (1971) Brit. J. Exp. Pathol., 52, 221-230.

54. Ando, K.; Kodama, K.; Kato, A.; Tamura, G. and Arima, K. (1972) Cancer Res., 32, 125129.

55. Boeryd, B. and Hallgren, B. (1980) Acta Path. Microbiol. Scand., A88, 11-18. 
56. Cabot, M.C.; Welsh, C.J. and Snyder, F. (1982) Biochim. Biophys. Acta, 713, 16-22.

57. Joo, C.N.; Shier, T. and Kates, M. (1968) J. Lipid Res., 9, 782-788.

58. Woese, C.R.; Kandler, O. and Wheelis, M.L. (1990) Proc. Natl. Acad. Sci. USA, 87, 45764579.

59. Mangold, H.K. and Weber, N. (1987) Lipids, 22, 789-799.

60. Shamsuddin, A.M.; Ullah, A.; Baten, A. and Hale, E. (1991) Carcinogenesis, 12, 601-607.

61. Zarkovic, M.; Qin, X.; Nakatsuru, Y.; Oda, H.; Nakamura, T.; Shamsuddin, A.M. and Ishikawa, T. (1993) Carcinogenesis, 14, 1261-1264.

62. Nakayama, R.; Yasuda, K.; Satouchi, K. and Saito, K. (1988) Biochem. Biophys. Res. Commun., 151, 1256-1261.

63. Lee, T.-C. (1998) Biochim. Biophys. Acta, 1394, 129-145.

64. Tessner, T.G. and Wykle, R.L. (1987) J. Biol. Chem., 262, 12660-12664.

65. Lohner, K.; Balgavy, P.; Hermetter, A.; Paltauf, F. and Laggner, P. (1991) Biochim. Biophys. Acta, 1061, 132-140.

66. Zoeller, R.A.; Morand, O.H. and Raetz, C.R. (1988) J. Biol. Chem., 263, 11590-11596.

67. Ford, D.A.; Hazen, S.L.; Saffitz, J.E. and Gross, R.W. (1991) J. Clin. Invest., 88, 331-335.

68. Glaser, P.E. and Gross, R.W. (1995) Biochemistry, 34, 12193-12203.

69. Thai, T.-P.; Rodemer, C.; Jauch, A.; Hunziker, A.; Moser, A.; Gorgas, K. and Just, W.W. (2001) Hum. Mol. Genet., 10, 127-136.

70. Ford, D.A. and Gross, R.W. (1994) Biochemistry, 33, 1216-1222.

71. Thomas, S.E.; Byers, D.M.; Palmer, F.B.St.C.; Spence, M.W. and Cook, H.W. (1990) Biochim. Biophys. Acta, 1044, 349-356.

72. Hazen, S.L.; Stuppy, R.J. and Gross, R.W. (1990) J. Biol. Chem., 265, 10622-10630.

73. Hazen, S.L.; Ford, D.A. and Gross, R.W. (1991) J. Biol. Chem., 266, 5629-5633.

74. Yang, H.-C.; Farooqui, A.A. and Horrocks, L.A. (1996) J. Lipid Mediat. Cell Signal., 14, 913.

75. Blank, M.L.; Wykle, R.L. and Snyder, F. (1973) Biochim. Biophys. Acta, 316, 28-34.

76. Ford, D.A. and Gross, R.W. (1989) Proc. Natl. Acad. Sci. USA, 86, 3479-3483.

77. Mollinedo, F.; Gómez-Cambronero, J.; Cano, E. and Sánchez-Crespo, M. (1988) Biochem. Biophys. Res. Commun., 154, 1232-1239.

78. Sugiura, T.; Fukuda, T.; Masuzawa, Y. and Waku, K. (1991) Biochim. Biophys. Acta, 1047, 223-232.

79. Uemura, Y.; Lee, T.-C. and Snyder, F. (1991) J. Biol. Chem., 266, 8268-8272. 
80. Nieto, M.L.; Venable, M.E.; Bauldry, S.A.; Greene, D.G:; Kennedy, M.; Bass, D.A. and Wykle, R.L. (1991) J. Biol. Chem., 266, 18699-18706.

81. Storch, J. and Munder, P.G. (1987) Lipids, 22, 813-819.

82. Heesbeen, E.C.; Verdonck, L.F.; Haagmans, M.; Van Heugten, H.G.; Staal, G.E.J. and Rijksen, G. (1993) Leukemia Res., 17, 143-148.

83. Fujiwara, K.; Daniel, L.W.; Modest, E.J. and Wallen, A. (1994) Cancer Chemother. Pharmacol., 34, 472-476.

84. Zoeller, R.A.; Layne, M.D. and Modest, E.J. (1995) J. Lipid Res., 36, 1866-1875.

85. Cabaner, C.; Gajate, C.; Macho, A.; Muñoz, E.; Modolell, M. and Mollinedo, F. (1999) Brit. J. Pharmacol., 127, 813-825.

86. May, G.L.; Wright, L.C.; Dyne, M.; Mackinnon, W.B.; Fox, R.M. and Mountford, C.E. (1988) Int. J. Cancer, 42, 728-733.

87. Hoffman, D.R.; Hoffman, L.H. and Snyder, F. (1986) Cancer Res., 46, 5803-5809.

88. van Blitterswijk, W.J.; Hilkmann, H. and Storme, G.A. (1987) Lipids, 22, 820-823.

89. Geilen, C.C.; Wieder, T.; Haase, A.; Reutter, W.; Morré, D.M. and Morré, D.J. (1994) Biochim. Biophys. Acta, 1211, 14-22.

90. Brown, R.E. (1992) Biochim. Biophys. Acta, 1113, 375-389.

91. Elamrani, K. and Blume, A. (1982) Biochemistry, 21, 521-526.

92. Mohandras, N.; Wyatt, J.; Mel, S.F.; Rossi, M.E. and Shohet, S.B. (1981) J. Biol. Chem., 257, 6537-6543.

93. Switzer, S. and Eder, A.H. (1965) J. Lipid Res., 6, 506-511.

94. Bazill, G.W. and Dexter, T.M. (1990) Cancer Res., 50, 7505-7512.

95. Kelley, E.E.; Modest, E.J. and Burns, C.P. (1993) Biochem. Pharmacol., 45, 2435-2439.

96. Kötting, J.; Marschner, N.W.; Neumüller, W.; Unger, C. and Eibl, H. (1992) in Progress in Experimental Tumor Reseach (Eibl, H.; Hilgard, P. and Unger, C., Eds.), Karger, Basel, Switzerland, vol. 34, pp 131-142.

97. Petersen, E.S.; Kelley, E.E.; Modest, E.J. and Burns, C.P. (1992) Cancer Res., 52, 62636269.

98. Heesbeen, E.C.; Rijksen, G.; van Heugten, H.G. and Verdonck, L.F. (1995) Leukemia Res., 19, 417-425.

99. van der Veer, E.; van der Weide, D.; Heijmans, H.S.A. and Hoekstra, D. (1993) Biochim. Biophys. Acta, 1146, 294-300.

100. Daleke, D.L. and Lyles, J.V. (2000) Biochim. Biophys. Acta, 1486, 108-127. 
101. van Helvoort, A.; Smith, A.J.; Sprong, H.; Fritzsche, I.; Schinkel, A.H.; Borst, P. and van Meer, G. (1996) Cell, 87, 507-517.

102. Ruetz, S.; Brault, M.; Dalton, W. and Gros, P. (1997) Biochemistry, 36, 8180-8188.

103. Oram, J.F.; Johnson, C.J. and Brown, T.A. (1987) J. Biol. Chem., 262, 2405-2410.

104. Schnitzer, J.E.; Carley, W.W. and Palade, G.E. (1988) Am. J. Physiol., 254, H425-H437.

105. Zoeller, R.A. and Raetz, C.R.H. (1986) Proc. Natl. Acad. Sci. USA, 83, 5170-5174.

106. Williams, L.T.; Tremble, P.M.; Lavin, M.F. and Sunday, M.E. (1984) J. Biol. Chem., 259, 5287-5294.

107. Betsholtz, C.; Johnsson, A.; Heldin, C.-H. and Westermark, B. (1986) Proc. Natl. Acad. Sci. USA, 83, 6440-6444.

108. Coffey, R.J.Jr.; Leof, E.B.; Shipley, G.D. and Moses, H.L. (1987) J. Cell. Physiol., 132, 143-148.

109. Yayon, A. and Klagsbrun, M. (1990) Proc. Natl. Acad. Sci. USA, 87, 5346-5350.

110. van der Bend, R.L.; Brunner, J.; Jalink, K.; van Corven, E.J.; Moolenaar, W.H. and van Blitterswijk, W.J. (1992) EMBO J., 11, 2495-2501.

111. Fortes, P.A.G.; Ellory, J.C. and Lew V.L. (1973) Biochim. Biophys. Acta, 318, 262-272.

112. Li, G.; Samadder, P.; Arthur, G. and Bittman, R. (2001) Tetrahedron, 57, 8925-8932.

113. Garcia, M.C.; Garcia, C.; Gijon, M.A.; Fernandez-Gallardo, S.; Mollinedo, F. and Sanchez-Crespo, M. (1991) Biochem. J., 273, 573-578.

114. Honda, Z.-I.; Nakamura, M.; Miki, I.; Minami, M.; Watanabe, T.; Seyama, Y.; Okado, H.; Toh, H.; Ito, K.; Miyamoto, T. and Shimizu, T. (1991) Nature, 349, 342-346.

115. Vallari, D.S.; Austinhirst, R. and Snyder, F. (1990) J. Biol. Chem., 265, 4261-4265.

116. Müller, E.; Dupuis, G.; Turcotte, S. and Rola-Pleszczynski, M. (1991) Biochem. Biophys. Res. Commun., 181, 1580-1586.

117. Vallari, D.S.; Smith, Z.L. and Snyder, F. (1988) Biochem. Biophys. Res. Commun., 156, $1-8$.

118. Alonso, M.T.; Gajate, C.; Mollinedo, F.; Modolell, M.; Alvarez, J. and García-Sancho, J. (1997) Brit. J. Pharmacol., 121, 1364-1368.

119. Salari, H.; Dryden, P.; Howard, S. and Bittman, R. (1992) Biochem. Cell Biol., 70, 129135.

120. Workman, P.; Donaldson, J. and Lohmeyer, M. (1991) Biochem. Pharmacol., 41, 319322. 
121. Mollinedo, F.; Santos-Beneit, A.M. and Gajate, C. (1998) in Animal Cell Culture Techniques (Clynes, M., Ed.), Springer-Verlag, Heidelberg, Germany, pp. 264-297.

122. Vallari, D.S.; Record, M.; Smith, Z.L. and Snyder, F. (1989) Biochim. Biophys. Acta, 1006, 250-25.

123. Tokumura, A.; Tsutsumi, T.; Nishioka, Y. and Tsukatani, H. (1997) Chem. Phys. Lipids, 86, 75-83.

124. Magistrelli, A.;Villa, P.; Benfenati, E.; Modest, E.J.; Salmona, M. and Tacconi, M.T. (1995) Drug Metab. Dispos., 23, 113-118.

125. Tietz, A.; Lindberg, M. and Kennedy, E.P. (1964) J. Biol. Chem., 239, 4081-4090.

126. Unger, C.; Eibl, H.,; Kim, D.J.; Fleer, E.A.; Kötting, J.; Bartsch, H.H.; Nagel, G.A. and Pfizenmaier, K. (1987) J. Natl. Cancer Inst., 78, 219-222.

127. Lu, X.; Zhou, X.; Kardash, D. and Arthur, G. (1993) Biochem. Cell Biol., 71, 122-126.

128. Unger, C.; Eibl, H.; von Heyden, H.-W. and Nagel, G.A. (1985) Cancer Res., 45, 616618.

129. Lee, T.-c.; Blank, M.L.; Fitzgerald, V., and Snyder, F. (1981) Arch. Biochem. Biophys., 208, 353-357.

130. Wilcox, R.W.; Wykle, R.L.; Schmitt, J.D. and Daniel, L.W. (1987) Lipids, 22, 800-807.

131. Van Blitterswijk, W.J.; van der Bend, R.L.; Kramer, I.J.M.; Verhoeven, A.J.; Hilkmann, H. and de Widt, J. (1987) Lipids, 22, 842-846.

132. Fleer, E.A.M.; Unger, C.; Kim, D.-J. and Eibl, H. (1987) Lipids, 22, 856-861.

133. Daniel, L.W.; Huang, C.; Strum, J.C.; Smitherman, P.K.; Greene, D., and Wykle, R.L. (1993) J. Biol. Chem., 268, 21519-21526.

134. Ukawa, K.; Imamiya, E.; Yamamoto, H.; Aono, T.; Kozai, Y.; Okutani, T.; Nomura, H.; Honma, Y.; Hozumi, M. and Kudo, I. (1989) Chem. Pharm. Bull. (Tokyo), 37, 32773285.

135. Bishop, F.E.; Dive, C.; Freeman, S. and Gescher, A. (1992) Cancer Chemother. Pharm., 31, 85-92.

136. Honma, Y.; Kasukabe, T.; Hozumi, M.; Akimoto, H. and Momura, H. (1991) Lipids, 26, 1445-1449.

137. Salari, H.; Howard, S. and Bittman, R. (1992) Biochem. Biophys. Res. Commun., 187, 603-608.

138. Marschner, N.; Kötting, J.; Eibl, H. and Unger, C. (1992) Cancer Chemother. Pharmacol., 31, 18-22. 
139. Arnold, B.; Reuther, R. and Weltzien, H.U. (1978) Biochim. Biophys. Acta, 530, 47-55.

140. Kobayashi, M. and Kanfer, J.N. (1987) J. Neurochem., 48, 1597-1603.

141. Shukla, S.D. and Halenda, S.P. (1991) Life Sci., 48, 851-866.

142. Balsinde, J. and Mollinedo, F. (1991) J. Biol. Chem., 266, 18726-18730.

143. Mollinedo, F.; Gajate, C. and Flores, I. (1994) J. Immunol., 153, 2457-2469.

144. Munder, P.G.; Modolell, M.; Andreesen, R.; Weltzien, H.U. and Westphal, O. (1979) Springer Semin. Immunopathol., 2, 187-203.

145. Andreesen, R.; Osterholz, J.; Luckenbach, G.A.; Costabel, U.; Schulz, A.; Speth, V.; Munder, P.G. and Löhr, G.W. (1984) J. Natl. Cancer Inst., 72, 53-59.

146. Scholar, E.M. (1986) Cancer Lett., 33, 199-204.

147. Goto, I.; Hozumi, M. and Honma, Y. (1994) Anticancer Res., 14, 357-362.

148. Boggs, K.P.; Rock, C.O. and Jackowski, S. (1995) J. Biol. Chem., 270, 11612-11618.

149. Peters, A.C.; Ahmad, I.; Janoff, A.S.; Pushkareva, M.Y. and Mayhew, E. (1997) Lipids, 32, $1045-1054$.

150. Diomede, L.; Piovani, B.; Re, F.; Principe, P.; Colotta, F.; Modest, E.J. and Salmona, M. (1994) Int. J. Cancer, 57, 645-649.

151. Roos, G. and Berdel, W.E. (1986) Leukemia Res., 10, 195-202.

152. Engebraaten, O.; Bjerkvig, R. and Berens, M.E. (1991) Cancer Res., 51, 1713-1719.

153. Principe, P.; Sidoti, C. and Braquet, P. (1992) Cancer Res., 52, 2509-2515.

154. Principe, P.; Sidoti, C.; Coulomb, H.; Broquet, C. and Braquet, P. (1994) Cancer Detect. Prev., 18, 393-400.

155. Fujiwara, K.; Modest, E.J. and Wallen, C.A. (1995) Anticancer Res., 15, 1333-1338.

156. Lohmeyer, M. and Workman, P. (1995) Brit. J. Cancer, 72, 277-286.

157. Pushkareva, M.Y.; Janoff, A.S. and Mayhew, E. (1999) Cell Biol. Int., 23, 817-828.

158. Herrmann, D.B.J. and Neumann, H.A. (1986) J. Biol. Chem., 261, 7742-7747.

159. Boggs, K.P.; Rock, C.O. and Jackowski, S. (1995) J. Biol. Chem., 270, 7757-7764.

160. Storme, G.A.; Berdel, W.E.; van Blitterswijk, K.J.; Bruyneel, E.; De Bruyne, G.K. and Mareel, M.M. (1985) Cancer Res., 45, 351-357.

161. Boggs, K.; Rock, C.O. and Jackowski, S. (1998) Biochim. Biophys. Acta, 1389, 1-12.

162. Gajate, C. and Mollinedo, F. (2001) Blood 98, 3860-3863.

163. Matzke, A.; Massing, U. and Krug, H.F. (2001) Eur. J. Cell Biol., 80, 1-10.

164. Gajate, C.; Santos-Beneit, A.; Modolell, M. and Mollinedo, F. (1998) Mol. Pharmacol. 53, 602-612. 
165. Gajate, C.; Santos-Beneit, A.M.; Macho, A.; Lazaro, M.C.; Hernandez-de Rojas, A.; Modolell, M.; Muñoz, E. and Mollinedo, F. (2000) Int. J. Cancer, 86, 208-218.

166. Ruiter, G.A.; Zerp, S.F.; Bartelink, H.; van Blitterswijk, W.J. and Verheij, M. (1999) Cancer Res., 59, 2457-2463.

167. Vrablic, A.S.; Albright, C.D.; Craciunescu, C.N.; Salganik, R.I. and Zeisel, S.H. (2001) FASEB J., 15, 1739-1744.

168. Mollinedo, F.; Gajate, C. and Modolell, M. (1994) Biochem. J., 302, 325-329.

169. Gajate, C.; Alonso, M.T.; Schimmang, T. and Mollinedo, F. (1996) Biochem. Biophys. Res. Commun., 218, 267-272.

170. Wolf, D. and Rotter, V. (1985) Proc. Natl. Acad. Sci. USA, 82, 790-794.

171. Folkman, J. (1971) N. Engl. J. Med., 285, 1182-1186.

172. Folkman, J. (1972) Ann. Surg., 175, 409-416.

173. O’Reilly, M.S.; Boehm, T.; Shing, Y.; Fukai, N.; Vasios, G.; Lane, W.S.; Flynn, E.; Birkhead, J.R.; Olsen, B.R. and Folkman, J. (1997) Cell, 88, 277-285.

174. Boehm, T.; Folkman, J.; Browder, T. and O’Reilly, M.S. (1997) Nature, 390, 404-407.

175. Ades, E.W., Candal, F.J., Swerlick, R.A., George, V.G., Summers, S., Bosse, D.C., and Lawley, T.J. (1992) J. Invest. Dermatol., 99, 683-690.

176. Candal, F.J.; Bosse, D.C.; Vogler, W.R. and Ades, E.W. (1994) Cancer Chemother. Pharmacol., 34, 175-178.

177. Vogler, W.R.; Liu, J.; Volpert, O.; Ades, E.W. and Bouck, N. (1998) Cancer Invest., 16, 549-553.

178. Tolsma, S.S.; Volpert, O.V.; Good, D.J.; Frazier, W.A.; Polverini, P.J. and Bouck, N. (1993) J. Cell Biol., 122, 497-511.

179. Andrade, S.P.; Vieira, L.B.; Bakhle, Y.S. and Piper, P.J. (1992) Int. J. Exp. Pathol., 73, 503-513.

180. Dobson, D.E., Kambe, A., Block, E.; Dion, T.; Lu, H.; Castellot, J.J.Jr. and Spiegelman, B.M. (1990) Cell, 61, 223-230.

181. Wakamatsu, K., Masaki, T., Itoh, F.; Kondo, K. and Sudok, K. (1990) Biochem. Biophys. Res. Comun., 168, 423-429.

182. Schallier, D.C.; Bruyneel, E.A.; Storme, G.A.; Hilgard, P. and Mareel, M.M. (1991) Anticancer Res., 11, 1285-1292.

183. Schallier, D.C.; Bruyneel, E.A.; Storme, G.A. and Mareel, M.M. (1991) Clin. Exp. Metastasis, 9, 579-591. 
184. Slaton, J.W.; Hampton, J.A. and Selman, S.H. (1994) J. Urology, 152, 1594-1598.

185. Storme, G.A.; Bruyneel, E.A.; Schallier, D.C.; Bolscher, J.G.; Berdel, W.E. and Mareel, M.M. (1987) Lipids, 22, 847-850.

186. Berdel, W.E. (1990) Onkologie, 13, 245-250.

187. Berdel, W.E.; Bausert, W.R.; Weltzien, H.U.; Modolell, M.L.; Widmann, K.H. and Munder, P.G. (1980) Eur. J. Cancer, 16, 1199-1204.

188. Berdel, W.E. and Munder, P.G. (1981) Anticancer Res., 1, 397-402.

189. Bolscher, J.G.M.; Schallier, D.C.; van Rooy, H.; Storme, G.A. and Smets, L.A. (1988) Cancer Res., 48, 977-982.

190. Haugland, H.K.; Nygaard, S.J. and Tysnes, O.B. (1999) Anticancer Res., 19, 149-156.

191. Bolscher, J.G.M.; Schallier, D.C.; Smets, L.A.; van Rooy, H.; Collard, J.G.; Bruyneel, E.A. and Mareel, M.M. (1986) Cancer Res., 46, 4080-4086.

192. Steelant, W.F.A.; Goeman, J.L:; Philippé, J.; Oomen, L.C.J.M.; Hilkens, J.; KrzewinskiRecchi, M.-A.; Huet, G.; van der Eycken, J.; Delannoy, P.; Bruyneel, E.A. and Mareel, M.M. (2001) Int. J. Cancer, 92, 527-536.

193. Bador, H.; Morelis, R. and Louisot, P. (1983) Int. J. Biochem., 15, 1137-1142.

194. Mjabri, B.; Boucrot, P.; and Aubry, J. (1990) Arch. Int. Physiol. Biochim., 98, 163-171.

195. van Larebeke, N.A.F.; Bruyneel, E.A. and Mareel, M.M. (1994) Clin. Exp. Metastasis, 12, 255-261.

196. Steelant, W.F.; Recchi, M.A.; Noe, V.T.; Boilly-Marer, Y.; Bruyneel, E.A.; Verbert, A.; Mareel, M.M. and Delannoy, P. (1999) Clin. Exp. Metastasis, 17, 245-253.

197. Honma, Y.; Kasukabe, T.; Hozumi, M.; Tsushima, S. and Nomura, H. (1981) Cancer Res., 41, 3211-3216.

198. Reed, C.B.; Tang, W. and Ziboh, V.A. (1991) Life Sci., 49, 1221-1227.

199. Berkovic, D.; Fleer, E.A.M.; Eibl, H. and Unger, C. (1992) Prog. Exp. Tumor Res., 34, 59-68.

200. Hilgard, P.; Stekar, J.; Voegeli, R. and Harleman, J.H. (1992) Prog. Exp. Tumor Res., 34, 116-130.

201. Pushkareva, M.Y.; Wannberg, S.L.; Janoff, A.S. and Mayhew, E. (2000) Cancer Immunol. Immunother., 48, 569-578.

202. Kent, C. (1990) Prog. Lipid Res, 29, 87-105.

203. Tronchère, H.; Record, M.; Tercé, F. and Chap, H. (1994) Biochim. Biophys. Acta, 1212, 137-151. 
204. Kent, C. (1995) Annu. Rev. Biochem., 64, 315-343.

205. Nagata, S. (1997) Cell, 88, 355-365.

206. Voelker, D.R. (1984) Proc. Natl. Acad. Sci. U.S.A., 81, 2669-2673.

207. Voelker, D.R. and Kennedy, E.P. (1982) Biochemistry, 21, 2753-2759.

208. Vogler, W.R.; Whigham, E.; Bennett, W.D. and Olson, A.C. (1985) Exp. Hematol., 13, 629-633.

209. Herrmann, D.B.J. (1985) J. Natl. Cancer. Inst., 75, 423-430.

210. Hoffman, D.R.; Thomas, V.L. and Snyder, F. (1992) Biochim. Biophys. Acta, 1127, 7480.

211. Tronchère, H.; Tercé, F.; Record, M.; Ribbes, G. and Chap, H. (1991) Biochem. Biophys. Res. Commun., 176, 157-165.

212. Esko, J.D. and Raetz, C.R.H. (1980) Proc. Natl. Acad. Sci. USA, 77, 5192-5196.

213. Esko, J.D.; Wermuth, M.M. and Raetz, C.R.H. (1981) J. Biol. Chem., 256, 7388-7393.

214. Esko, J.D.; Nishijima, M. and Raetz, C.R.H. (1982) Proc. Natl. Acad. Sci. USA, 79, 16981702.

215. Cui, Z.; Houweling, M.; Chen, M.H.; Record, M.; Chap, H.; Vance, D.E. and Tercé, F. (1996) J. Biol. Chem., 271, 14668-14671.

216. Cornell, R.B. (1991) Biochemistry, 30, 5873-5880.

217. Cornell, R.B. (1991) Biochemistry, 30, 5881-5888.

218. Utal, A.K.; Jamil, H. and Vance, D.E. (1991) J. Biol. Chem., 266, 24084-24091.

219. Wright, P.S.; Morand, J.N. and Kent, C. (1985) J. Biol. Chem., 260, 7919-7926.

220. Pelech, S.L.; Cook, H.W.; Paddon, H.B. and Vance, D.E. (1984) Biochim. Biophys. Acta, 795, 433-440.

221. Sleight, R. and Kent, C. (1983) J. Biol. Chem., 258, 836-839.

222. Yao, Z.; Jamil, H. and Vance, D.E. (1990) J. Biol. Chem., 265, 4326-4331.

223. Sohal, P.S. and Cornell, R.B. (1990) J. Biol. Chem., 265, 11746-11750.

224. Jackowski, S. (1994) J. Biol. Chem., 269, 3858-3867.

225. Watkins, J.D. and Kent, C. (1990) J. Biol. Chem., 265, 2190-2197.

226. Watkins, J.D. and Kent, C. (1991) J. Biol. Chem., 266, 21113-21117.

227. Wang, Y.; Sweitzer, T.D.; Weinhold, P.A. and Kent, C. (1993) J. Biol. Chem., 268, 58995904.

228. Wang, Y. and Kent, C. (1995) J. Biol. Chem., 270, 17843-17849. 
229. Kalmar, G.B.; Kay, R.J.; LaChance, A.; Aebersold, R. and Cornell, R.B. (1990) Proc. Natl. Acad. Sci. USA, 87, 6029-6033.

230. Sweitzer, T.D. and Kent, C. (1994) Arch. Biochem. Biophys., 311, 107-116.

231. Rutherford, M.S.; Rock, C.O.; Jenkins, N.A.; Gilbert, D.J.; Tessner, T.G.; Copeland, N.G. and Jacowski, S. (1993) Genomics, 18, 698-701.

232. Kalmar, G.B.; Kay, R.J.; LaChance, A.C. and Cornell, R.B. (1994) Biochim. Biophys. Acta, 1219, 328-334.

233. Lykidis, A.; Murti, K.G. and Jackowski, S. (1998) J. Biol. Chem., 273, 14022-14029.

234. Morand, J.N. and Kent, C. (1989) J. Biol. Chem., 264, 13785-13792.

235. Vance, J.E. and Vance, D.E. (1988) J. Biol. Chem., 263, 5898-5909.

236. Slomiany, A.; Grzelinska, E.; Kasinathan, C.; Yamakil, K.-I.; Palecz, D.; Slomiany, B.A. and Slomiany, B.L. (1992) Exp. Cell Res., 201, 321-329.

237. Haase, R.; Wieder, T.; Geilen, C.C. and Reutter, W. (1991) FEBS Lett., 288, 129-132.

238. Geilen, C.C.; Wieder, T. and Reutter, W. (1992) J. Biol. Chem., 267, 6719-6724.

239. Wieder, T.; Geilen, C.C. and Reutter, W. (1993) Biochem. J., 291, 561-567.

240. Detmar, M.; Geilen, C.C.; Wieder, T.; Orfanos, C.E. and Reutter, W. (1994) J. Invest. Dermatol., 102, 490-494.

241. Zhou, X. and Arthur, G. (1995) Eur. J. Biochem., 232, 881-888.

242. Wieder, T.; Haase, A.; Geilen, C.C. and Orfanos, C.E. (1995) Lipids, 30, 389-393.

243. Berkovic, D.; Grunwald, U.; Menzel, W.; Unger, C.; Hiddemann, W. and Fleer, E.A.M. (1995) Eur. J. Cancer, 31, 2080-2085.

244. Besterman, J.M. and Domanico, P.L. (1992) Biochemistry, 31, 2046-2056.

245. Baburina, I. and Jackowski, S. (1998) J. Biol. Chem., 273, 2169-2173.

246. Steelant, W.F.A.; Bruyneel, E.A.; Mareel, M.M. and van den Eeckhout, E.G. (1995) Anal. Biochem., 227, 246-250.

247. Vogler, W.R.; Shoji, M.; Hayzer, D.J.; Xie, Y.P. and Renshaw, M. (1996) Leukemia Res., 20, 947-951.

248. Lu, X. and Arthur, G. (1992) Cancer Res., 52, 2806-2812.

249. Lu, X. and Arthur, G. (1992) Cancer Res., 52: 2813-2817.

250. Winkler, J.D.; Eris, T.; Sung, C.-M.; Chabot-Fletcher, M.; Mayer, R.J.; Surette, M.E. and Chilton, F.H. (1996) J. Pharmacol. Exp. Ther., 279, 956-966.

251. Kramer, R.M. and Deykin, D. (1983) J. Biol. Chem., 258, 13806-13811. 
252. Chilton, F.H.; O’Flaherty, J.T.; Ellis, J.M.; Swendsen, C.L. and Wykle, R.L. (1983) J. Biol. Chem., 258, 7268-7271.

253. Sugiura, T.; Masuzawa, Y.; Nakagawa, Y. and Waku, K. (1987) J. Biol. Chem., 262, 1199-1205.

254. Chilton, F.H.; Fonteh, A.N.; Surette, M.E.; Triggiani, M. and Winkler, J.D. (1996) Biochim. Biophys. Acta, 1299, 1-15.

255. Snyder, F. and Wood, R. (1968) Cancer Res., 28, 972-978.

256. Snyder, F. and Wood, R. (1969) Cancer Res., 29, 251-257.

257. Chabot, M.C.; Wykle, R.L.; Modest, E.J. and Daniel, L.W. (1989) Cancer Res., 49, 44414445.

258. Cosulich, S. and Clarke, P. (1996) Curr. Biol., 6, 1586-1588.

259. Canman, C.E. and Kastan, M.B. (1996) Nature, 384, 213-214.

260. Zhou, X.; Lu, X.; Richard, C.; Xiong, W.; Litchfield, D.W.; Bittman, R. and Arthur, G. (1996) J. Clin. Invest., 98, 937-944.

261. Powis, G.; Seewald, M.J.; Gratas, C.; Melder, D.; Riebow, J. and Modest, E.J. (1992) Cancer Res., 52, 2509-2515.

262. Goldschmidt-Clermont, P.J.; Kim, J.W.; Machesky, L.M:; Rhee, S.G. and Pollard, T.D. (1991) Science, 251, 1231-1233.

263. Strassheim, D.; Shafer, S.H.; Phelps, S.H. and Williams, C.L. (2000) Cancer Res., 60, 2730-2736.

264. Kosano, H. and Takatani, O. (1988) Cancer Res., 48, 6033-6036.

265. Marte, B.M.; Rodriguez-Viciana, P.; Wennstrom, S.; Warne, P.H. and Downward, J. (1997) Curr. Biol., 7, 63-70.

266. Berggren, M.I.; Gallegos, A.; Dressler, L.A.; Modest, E.J. and Powis, G. (1993) Cancer Res., 53, 4297-4302.

267. Hu, Y.; Meuillet, E.J.; Qiao, L.; Berggren, M.M., Powis, G. and Kozikowski, A.P. (2000) Tetrahedron Lett., 41, 7415-7418.

268. Wagner, B.A.; Buettner, G.R.; Oberley, L.W. and Burns, C.P. (1998) Cancer Res., 58, 2809-2816.

269. Wagner, B.A.; Buettner, G.R. and Burns, C.P. (1992) Cancer Res., 52, 6045-6051.

270. Bukau, B. and Horwich, A.L. (1998) Cell, 92, 351-366.

271. Hightower, L.E. (1991) Cell, 66, 191-197.

272. Jäättela, M. (1999) Exp. Cell Res., 248, 30-43. 
273. Renis, M.; Cardile, V.; Russo, A.; Campisi, A. and Collovà, F. (1998) Brain Res., 783, 143-150.

274. Botzler, C.; Kolb, H.J.; Issels, R.D. and Multhoff, G. (1996) Int. J. Cancer, 65, 633-638.

275. Tidwell, W.; Guzman, G. and Vogler, W.R. (1981) Blood, 57, 794-797.

276. Multhoff, G.; Botzler, C.; Wiesnet, M.; Eissner, G. and Issels, R. (1995) Blood, 86, 13741382.

277. Botzler, C.; Issels, R. and Multhoff, G. (1996) Cancer Immunol. Immunother., 43, 226230.

278. Multhoff, G.; Botzler, C.; Jennen, L.; Schmidt, J.; Ellwart, J. and Issels, R. (1997) J. Immunol., 158, 4341-4350.

279. Botzler, C.; Ellwart, J.; Günther, W.; Eißner, G. and Multhoff, G. (1999) Exp. Hematol., 27, 470-478.

280. Fujiwara, K.; Shirafuji, H.; Fushitani, K.; Fujimoto, K.; Kohno, I. and Modest, E.J. (1999) Anticancer Res., 19, 181-188.

281. Garrido, C.; Ottavi, P.; Fromentin, A.; Hammann, A.; Arrigo, A.P.; Chauffert, B. and Mehlen, P. (1997) Cancer Res., 57, 2661-2667.

282. Biggiogera, M.; Tanguay, R.M.; Marin, R.; Wu, Y.; Martin, T.E. and Fakan, S. (1996) Exp. Cell. Res., 229, 77-85.

283. Jarvis, W.D.; Turner, A.J.; Povirk, L.F.; Traylor, R.S. and Grant, S. (1994) Cancer Res., 54, 1707-1714.

284. Nishizuka, Y. (1995) FASEB J., 9, 484-496.

285. Buchner, K. (1995) Eur. J. Biochem., 228, 211-221.

286. Helfman, D.M.; Barnes, K.C.; Kinkade, J.M.; Vogler, W.R.; Shoji, M. and Kuo, J.F. (1983) Cancer Res., 43, 2955-2961.

287. Shoji, M.; Raynor, R.L.; Berdel, W.E.; Vogler, W.R. and Kuo, J.F. (1988) Cancer Res., 48, 6669-6673.

288. Überall, F.; Oberhuber, H.; Maly, K.; Zaknun, J.; Demuth, L. and Grunicke, H.H. (1991) Cancer Res., 51, 807-812.

289. Heesbeen, E.C.; Verdonck, L.F.; Hermans, S.W.G.; van Heugten, H.G.; Staal, G.E.J. and Rijksen, G. (1991) FEBS Lett., 290, 231-234.

290. Berkovic, D.; Berkovic, K.; Fleer, E.A.M.; Eibl, H. and Unger, C. (1994) Eur. J. Cancer, 30, 509-515. 
291. Heesbeen, E.C.; Verdonck, L.F.; Staal, G.E.J. and Rijksen, G. (1994) Biochem. Pharmacol., 47, 1481-1488.

292. Salari, H.; Dryden, P.; Davenport, R.; Howard, S.; Jones, K. and Bittman, R. (1992) Biochim. Biophys. Acta, 1134, 81-88.

293. Zhou, X. and Arthur, G. (1997) Biochem. J., 324, 897-902.

294. Kiss, Z.; Deli, E.; Vogler, W.R. and Kuo, J.F. (1987) Biochem. Biophys. Res. Commun., 142, 661-666.

295. Parker, J.; Daniel, L.W. and Waite, M. (1987) J. Biol. Chem., 262, 5385-5393.

296. Daniel, K.W.; Etkin, L.A.; Morrison, B.T.; Parker, J.; Morris-Natschke, S.; Surles, J.R. and Piantadosi, C. (1987) Lipids, 22, 851-855.

297. Jarvis, W.D.; Fornari, F.A.; Browning, J.L.; Gewirtz, D.A.; Kolesnick, R.N. and Grant, S. (1994) J. Biol. Chem., 269, 31685-31692.

298. Frei, E.; Bickers, J.N.; Hewitt, M.; Leary, W.V. and Talley, R.W. (1969) Cancer Res., 29, 1325-1332.

299. Jarvis, W.D.; Povirk, L.F.; Turner, A.J.; Traylor, R.S.; Gewirtz, D.A.; Pettit, G.R. and Grant, S. (1994) Biochem. Pharmacol., 47, 839-852.

300. Whitman, S.P.; Civoli, F. and Daniel, L.W. (1997) J. Biol. Chem., 272, 23481-23484.

301. Kiss, Z. and Crilly, K.S. (1997) FEBS Lett., 412, 313-317.

302. Daniel, L.W.; Civoli, F.; Rogers, M.A.; Smitherman, P.K.; Raju, P.A. and Roederer, M. (1995) Cancer Res., 55, 4844-4849.

303. Marasco, C.J.; Piantadosi, C.; Meyer, K.L.; Morris-Natschke, S., Ishaq, K., Small, G.W. and Daniel, L.W. (1990) J. Med. Chem., 33, 985-992.

304. Civoli, F. and Daniel, L.W. (1998) Cancer Chemother. Pharmacol., 42, 319-326.

305. Perkins, W.R.; Dause, R.B.; Li, X.; Franklin, J.C.; Cabral-Lilly, D.J.; Zha, Y.; Dank, E.H.; Mayhew, E. and Janoff, A.S. (1997) Biochim. Biophys. Acta, 1327, 61-68.

306. Spiegel, S.; Olah, Z.; Cuvillier, O.; Edsall, L.C. and Janoff, A.S. (1999) FEBS Lett., 454, 137-141.

307. Muschiol, C.; Berger, M.R.; Schuler, B.; Scherf, H.R.; Garzon, F.T.; Zeller, W.J.; Unger, C.; Eibl, H.J. and Schmäl, D. (1987) Lipids, 22, 930-934.

308. Munder, P.G.; Modolell, M.; Bausert, W.; Oettgen, H.F. and Westphal, O. (1981) in Augmenting Agents in Cancer Therapy (Hersh, E.M., Ed.) Raven Press, New York, pp. 441-458. 
309. King, M.-T.; Eckhardt, K.; Gocke, E.; Wild, D.; Berdel, W.E. and Munder, P.G. (1981) Cancer Lett., 12, 217-222.

310. Bauchinger, M.; Dresp, J.; Schmid, E. and Berdel, W.E. (1983) Mutation Res., 121, 225231.

311. Schaefer, H.G. and Rohdewald, P. (1989) Clin. Chem., 35, 821-823.

312. Servillo, L.; Iorio, E.L.; Quagliuolo, L.; Camussi, G.; Balestrieri, C. and Giovane, A. (1997) J. Chromatogr. B, 689, 281-286.

313. Brouwers, J.F.H.M.; Gadella, B.M.; van Golde, L.M.G. and Tielens, A.G.M. (1998) L. Lipid. Res., 39, 344-353.

314. Lesnefsky, E.J.; Stoll, M.S.K.; Minkler, P.E. and Hoppel, C.L. (2000) Anal. Biochem., 285, 246-254.

315. Yokoyama, K.; Shimizu, F. and Setaka, M. (2000) J. Lipid Res., 41, 142-147.

316. Thaler, A.; Hottkowitz, T. and Eibl, H. (2000) Chem. Phys. Lipids, 107, 131-139.

317. Woo, E.W.; Messmann, R.; Sausville, E.A. and Figg, W.D. (2001) J. Chromatogr. B, 759, 247-257.

318. Unger, C.; Fleer, E.A.M.; Damenz, W.; Hilgard, P.; Nagel, G. and Eibl, H. (1991) J. Lipid Mediators, 3, 71-78.

319. Plotzke, K.P.; Fisher, S.J.; Wahl, R.L.; Olken, N.M.; Skinner, S.; Gross, M.D. and Counsell, R.E. (1993) J. Nucl. Med., 34, 787-792.

320. Meyer, K.L.; Schwendner, S.W. and Counsell, R.E. (1989) J. Med. Chem., 32, 21422147.

321. Counsell, R.E.; Schwendner, S.W.; Meyer, K.L.; Haradahira, T. and Gross, M.D. (1990) J. Nucl. Med., 31, 332-336.

322. Rampy, M.A.; Brown, R.S.; Pinchuk, A.N.; Weichert, J.P.; Skinner, R.W.S.; Fisher, S.J.; Wahl, R.L.; Gross, M.D.; Ethier, S.P. and Counsell, R.E. (1996) J. Nucl. Med., 37, 15401545.

323. Scherf, H.R.; Schuler, B.; Berger, M.R. and Schmähl, D. (1987) Lipids, 22, 927-929.

324. Berger, M.R.; Munder, P.G.; Schmähl, D. and Westphal, O. (1984) Oncology, 41, 109113.

325. Berger, M.R. and Schmähl, D. (1987) Lipids, 22, 935-942.

326. Heim, M.E.; Swoboda, M.; Pahlke, W.; Edler, L. and Bicker, U. (1984) J. Cancer Res. Clin. Oncol., 108, 316-320. 
327. Runge, M.H.; Andreesen, R.; Pfleiderer, A. and Munder, P.G. (1980) J. Natl. Cancer Inst., 64, 1301-1306.

328. Leder, G.H.; Fiebig, H.H.; Wallbrecher, E.; Winterhalter, B.R. and Löhr, G.W. (1987) Lipids, 22, 958-961.

329. Hardman, W.E.; Barnes, C.J.; Knight, C.W. and Cameron, I.L. (1997) Br. J. Cancer, 76, 347-354.

330. Zeller, W.J.; Bauer, S.; Remmele, T.: Wowra, B.; Sturm, V. and Stricker, H. (1990) Cancer Treat. Rev., 17, 183-189.

331. Berdel, W.E.; Schlehe, H.; Fink, U.; Emmerich, B.; Maubach, P.A.; Emslander, H.P.; Daum, S. and Rastetter, J. (1982) Cancer, 50, 2011-2015.

332. Berdel, W.E.; Fink, U.; Maubach, P.A.; Permanetter, B. and Rastetter, J. (1982) Blut, 44, 177-186.

333. Berdel, W.E.; Fink, U. and Rastetter, J. (1987) Lipids, 22, 967-969.

334. Drings, P.; Günther, I.; Gatzemeier, U.; Ulbrich, F.; Khanavkar, B.; Schreml, W.; Lorenz, J.; Brugger, W.; Schick, H.D.; Pawel, J.V. and Nordstrom, R. (1992) Onkologie, 15, 375382.

335. Vogler, W.R.; Whigham, E.A.; Somberg, L.B.; Long, R.C., Jr. and Winton, E.F. (1984) Exp. Hematol., 12, 569-574.

336. Dulisch, I.; Neumann, H.A.,; Löhr, G.W. and Andreesen, R. (1985) Blut, 51, 393-399.

337. Schick, H.D.; Berdel, W.E.; Fromm, M.; Fink, U.; Jehn, U.; Ulm, K.; Reichert, A.; Eibl, H.; Unger, C. and Rastetter, J. (1987) Lipids, 22, 904-910.

338. Verdonck, L.F.; Witteveen, E.O.; van Heugten, H.G.; Rozemuller, E. and Rijksen, G. (1990) Cancer Res., 50, 4020-4025.

339. Okamoto, S.; Olson, A.C.; Vogler, W.R. and Winton, E.F. (1987) Blood, 69, 1381-1387.

340. Okamoto, S.; Olson, A.C.; Berdel, W.E. and Vogler, W.R. (1988) Blood, 72, 1777-1783.

341. Glasser, L.; Somberg, L.B. and Vogler, W.R. (1984) Blood, 64, 1288-1291.

342. Vogler, W.R.; Somberg, L.B. and Glasser, L. (1987) Exp. Hematol., 15, 360-364.

343. Gribben, J.G.; Freedman, A.S.; Neuberg, D.; Roy, D.C.; Blake, K.W.; Woo, S.D.; Grossbard, M.L.; Rabinowe, S.N.; Coral, F. and Freeman, G.J. (1991) New Engl. J. Med., 325, 1525-1533.

344. Uckun, F.M.; Kersey, J.H.; Haake, R.; Weisdorf, D.; Nesbit, M.E. and Ramsay, N.K. (1993) New Engl. J. Med., 329, 1296-1301. 
345. Brenner, M.K.; Rill, D.R.; Moen, R.C.; Krance, R.A.; Mirro, J.Jr.; Anderson, W.F. and Ihle, J.N. (1993) Lancet, 341, 85-86.

346. Rill, D.R.; Santana, V.M.; Roberts, W.M.; Nilson, T.; Bowman, L.C.; Krance, R.A.; Heslop, H.E.; Moen, R.C.; Ihle, J.N. and Brenner, M.K. (1994) Blood, 84, 380-383.

347. Vogler, W.R.; Olson, A.C.; Okamoto, S.; Somberg, L.B. and Glasser, L. (1987) Lipids, 22, 919-923.

348. Vogler, W.R.; Berdel, W.E.; Olson, A.C.; Winton, E.F.; Heffner, L.T. and Gordon, D.S. (1992) Blood, 80, 1423-1429.

349. Vogler, W.R. and Berdel, W.E. (1993) J. Hematotherapy, 2, 93-102.

350. Vogler, W.R. (1994) Leukemia and Lymphoma, 13, 53-60.

351. Kaizer, H.; Stuart, R.K.; Brookmeyer, R.; Beschorner, W.E.; Braine, H.G.; Burns, W.H.;

Fuller, D.J.; Körbling, M.,; Mangan, K.F.; Saral, R.; Sensenbrenner, L.; Shadduck, R.K.;

Shende, A.C.; Tutschka, P.J.; Yeager, A.M.; Zinkham, W.H.; Colvin, O.M. and Santos, G.W. (1985) Blood, 65, 1504-1510.

352. Rowley, S.D.; Zuehlsdorf, M.; Braine, H.D.; Colvin, O.M.; Davis, J.; Jones, R.J.; Saral, R.; Sensenbrenner, L.L:; Yeager, A. and Santos, G.W. (1987) Blood, 70, 271-275.

353. Rosenfeld, C.; Shadduck, R.K.; Przepiorka, D.; Mangan, K.F. and Colvin, M. (1989) Blood, 74, 1159-1164.

354. Kessinger, A. and Armitage, J.O. (1991) Blood, 77, 211-213.

355. Sheridan, W.P.; Begley, C.G.; Juttner, C.A.; Szer, J.; To, L.B.; McGrath, K.M.; Morstyn, G. and Fox, R.M. (1992) Lancet, 339, 640-644.

356. Koenigsmann, M.P.; Notter, M.; Knauf, W.U.; Papadimitriou, C.A.; Oberberg, D.; Reufi, B.; Mücke, C.; Thiel, E. and Berdel, W.E. (1996) Bone Marrow Transplant., 18, 549557.

357. Yamazaki, T. and Sieber, F. (1997) Bone Marrow Transplant., 19, 113-119.

358. Andreesen, R.; Modolell, M.; Oepke, G.H.; Common, H.; Löhr, G.W. and Munder, P. (1982) Anticancer Res., 2, 95-100.

359. Clay, K.L.; Johnson, C. and Henson, P. (1990) Biochim. Biophys. Acta, 1046, 309-314.

360. Spector, A.A. (1975) J. Lipid. Res., 16, 165-179.

361. Symonds, R.P.; Wheldon, T.E.; Clarke, B. and Bailey, G. (1981) Br. J. Cancer, 44, 682691.

362. Moriyama, Y.; Narita, M.; Sato, K.; Urushiyama, M.; Koyama, S.; Hirosawa, H.; Kishi, K.; Takahashi, M.; Takai, K. and Shibata, A. (1986) Blood, 67, 802-804. 
363. Eddy, D.M. (1992) J. Clin. Oncol., 10, 657-670.

364. Dieztfelbinger, H.F.; Kühn, D.; Zafferani, M.; Hanauske, A.R.; Rastetter, J.W. and Berdel, W.E. (1993) Cancer Res., 53, 3747-3751.

365. Andreesen, R. and Munder, P.G. (1983) J. Natl. Cancer Inst., 70, 623-627.

366. Papahadjopoulos, D.; Allen, T.M.; Gabizon, A.; Mayhew, E.; Matthay, K.; Huang, S.K.; Lee, K.D., Woodle, M.C.; Lasic, D.D.; Redemann, C. and Martin, F.J. (1991) Proc. Natl. Acad. Sci. USA, 88, 11460-11464.

367. Szoka, F.C. and Tang, M. (1993) J. Liposome Res., 3, 363-375.

368. Cowens, J.W.; Creaven, P.J.; Greco, W.R.; Brenner, D.E.; Tung, Y.; Ostro, M.; Pilkiewicz, F.; Ginsberg, R. and Petrelli, N. (1993) Cancer Res., 53, 2796-2802.

369. Sharma, A.; Mayhew, E. and Straubinger, R.M. (1993) Cancer Res., 53, 5877-5881.

370. Vaage, J.; Donovan, D.; Mayhew, E.; Uster, P. and Woodle, M. (1993) Int. J. Cancer, 54, 959-964.

371. Ahmad, I.; Filep, J.J.; Franklin, J.C.; Janoff, A.S.; Masters, G.R.; Pattassery, J.; Peters, A.; Schupsky, J.J.; Zha, Y. and Mayhew, E. (1997) Cancer Res., 57, 1915-1921.

372. Mayhew, E.; Ahmad, I.; Bhatia, S.; Dause, R.; Filep, J.; Janoff, A.S.; Kaisheva, E.; Perkins, W.R.; Zha, Y. and Franklin, J.C. (1997) Biochim. Biophys. Acta, 1329, 139-148.

373. Cuvillier, O.; Mayhew, E.; Janoff, A.S. and Spiegel, S. (1999) Blood, 94, 3583-3592.

374. Kotting, J.; Marschner, N.W.; Neumuller, W.; Unger, C. and Eibl, H. (1992) Prog. Exp. Tumor Res., 34, 131-142.

375. Gabizon, A.A. (1995) Adv. Drug Delivery Rev., 16, 285-294.

376. Bogers, W.M.J.M.; Stad, R.K.; Janssen, D.J.; Rits, M.; Bazin, H.; van Es, L.A. and Daha, M.R. (1991) Eur. J. Immunol., 21, 1093-1099.

377. Bogers, W.M.J.M.; van Rooijen, N.; Janssen, D.J.; van Es, L.A. and Daha, M.R. (1993) Eur. J. Immunol., 23, 433-438.

378. Ahl, P.L.; Bhatia, S.K.; Meers, P.; Roberts, P.; Stevens, R.; Dause, R.; Perkins, W.R. and Janoff, A.S. (1997) Biochim. Biophys. Acta, 1329, 370-382.

379. Baker, D.; O’Neill, J.K.; Amor, S.; Khamashta, M.A. and Turk, J.L. (1991) Int. J. Immunopharmacol., 13, 385-392.

380. Klein-Franke, A. and Munder, P.G. (1992) J. Autoimmun., 5, 83-91.

381. Chabannes, D.; Ryffel, B. and Borel, J.-F. (1992) J. Autoimmun., 5, 199-211.

382. Kovarik, J.; Chabannes, D. and Borel, J.F. (1995) Int. J. Immunopharmacol., 17, 255263. 
383. Zamvil, S.; Nelson, P.; Trotter, J.; Mitchell, D.; Knbler, R.; Fritz, R. and Steinman, L. (1985) Nature, 317, 355-358.

384. Satoh, J.; Sakai, K.; Endoh, M.; Koike, F.; Kunishita, T.; Namikawa, T.; Yamamura, T. and Tabira, T. (1987) J. Immunol. 138, 179-184.

385. Acha-Orbea, H.; Mitchell, D.J.; Timmermann, L.; Wraith, D.C.; Tausch, G.S.; Waldor, M.K.; Zamvil, S.S.; McDevitt, H.O. and Steinman, L. (1988) Cell, 54, 263-273.

386. Engelhardt, B.; Diamantstein, T. and Werkerle, H. (1898) J. Autoimmun., 2, 61-73.

387. Andreesen, R.; Modolell, M.; Weltzien, H.U. and Munder, P.G. (1979) Immunobiology, 156, 498-508.

388. Piantadosi, C.; Marasco, C.J.Jr.; Morris-Natschke, S.L.; Meyer, K.L.; Gumus, F.; Surles, J.R.; Ishaq, K.S.; Kucera, L.S.; Yyer, N. and Wallen, C.A. (1991) J. Med. Chem., 34, 1408-1414.

389. Kucera, L.S.; Iyer, N.; Leake, E.; Raben, A.; Modest, E.J.; Daniel, L.W. and Piantadosi, C. (1990) AIDS Res. Hum. Retroviruses, 6, 491-501.

390. Achterberg, V. and Gercken, G. (1987) Mol. Biochem. Parasit., 23, 117-122.

391. Croft, S.L.; Neal, R.A.; Pendergast, W. and Chan, J.H. (1987) Biochem. Parasitol., 36, 2633-2636.

392. Fiavey, N.P. and Ngwenya, B.Z. (1991) Am. J. Trop.Med. Hyg., 143, 119-120.

393. Croft, S.L.; Neal, R.A.; Thornton, E.A. and Herrmann, D.B.J. (1993) Trans. Roy. Soc. Trop. Med. Hyg., 87, 217-219.

394. Croft, S.L.; Snowdon, D. and Yardley, V. (1996) J. Antimicro. Chemother., 38, 10411047.

395. Konstantinov, S.M.; Kaminsky, R.; Brun, R.; Berger, M.R. and Zillmann, U. (1997) Acta Trop., 64, 145-154.

396. Jha, T.K.; Sundar, S.; Thakur, C.P.; Bachmann, P.; Karbwang, J.; Fischer, C.; Voss, A. and Berman, J. (1999) N. Engl. J. Med., 341, 1795-1800.

397. Murray, H.W. (2000) Antimicrob. Agents Chemother., 44, 3235-3236.

398. Santa-Rita, R.M.; Barbosa, H.S.; Meirelles, M.N.S.L. and de Castro, S.L. (2000) Acta Trop., 75, 219-228.

399. Seifert, K.; Duchêne, M.; Wernsdorfer, W.H.; Kollaritsch, H.; Scheiner, O.; Wiedermann, G.; Hottkowitz, T. and Eibl, H. (2001) Antimicrob. Agents Chemother., 45, 1505-1510.

400. Alvar, J.; Cañavate, C.; Gutiérrez-Solar, B.; Jiménez, M.; Laguna, F.; López-Vélez, R.; Molina, R. and Moreno, J. (1997) Clin. Microbiol. Rev., 10, 298-319. 
401. Jha, T.K.; Sundar, S.; Thakur, C.P.; Bachmann, P.; Karbwang, J.; Fischer, C.; Voss, A. and Berman, J. (1999) N. Engl. J. Med., 341, 1795-1800.

402. Beach, D.H.; Holz, G.G. and Anekwe, G.E. (1979) J. Parasitol., 65, 203-216.

403. Herrmann, H.O. and Gercken, G. (1980) Lipids, 15, 179-186.

404. Herrmann, H.O. and Gercken, G. (1980) Hoppe-Seyler's Z. Physiol. Chem, 361, 17351742

405. Wassef, M.K.; Fioretti, T.B. and Dwyer, D.M. (1985) Lipids, 20, 108-115.

406. Achterberg, V. and Gercken, G. (1987) Mol. Biochem. Parasit., 26, 277-287.

407. Lux, H.; Heise, N.; Klenner, T.; Hart, D. and Opperdoes, F.R. (2000) Mol. Biochem. Parasit., 111, 1-14. 


\section{$\underline{\text { LEGENDS TO FIGURES }}$}

Fig. (1). Chemical structures of $\mathrm{ET}-18-\mathrm{OCH}_{3}$ (edelfosine), platelet-activating factor (PAF) and hexadecylphosphocholine (HPC, miltefosine).

Fig. (2). Normal and cancer cells show different "apoptosis thresholds" in response to cellular and genomic damage. A deficient apoptotic response in cancer cells increases their malignancy, favoring accumulation of mutations and rendering tumor cells resistant to therapy.

Fig. (3). Response to cellular or genomic damage. Cancer cells inhibit the expression or activity of cellular sensors that engage apoptosis, as well as inhibit apoptotic signaling and/or enhance survival signaling, rendering a high "apoptosis threshold” and providing cancer cells with a high survival capacity in adverse conditions.

Fig. (4). Metabolism of 2-lysophosphatidylcholine.

Fig. (5). ET-18-OCH 3 -induced apoptosis and ether lipid uptake depend on the malignant state of the cells.

Fig. (6). Metabolic pathways of ET-18-OCH 3 . GEMO, glyceryl-ether monooxygenase. PLA phospholipase $\mathrm{A}_{2}$. PLC, phospholipase C. PLD, phospholipase D.

Fig. (7). Antitumor effects of ET-18-OCH3.

Fig. (8). Hypothetical model for the proapoptoitc effect of ET-18-OCH $\mathrm{OCH}_{3}$ in tumor cells. First, ET$18-\mathrm{OCH}_{3}$ is taken up selectively by tumor cells, but not by normal cells, through its interaction with a still unknown cell surface structure (denoted as “?”), and then the ether lipid induces the intracellular activation of Fas/CD95. This second step is non-selective and involves Fas/CD95 capping and activation, JNK, mitochondria, caspase-3 and internucleosomal DNA degradation. Modified from [12]. 
Fig. (9). Interaction of ET-18-OCH 3 with different cellular regulatory and signaling events in relation to its cytotoxic activity. CK, choline kinase. CPT, choline phosphotransferase. DAG, diacylglycerol. 